Prepared in cooperation with the Missouri Department of Transportation

\title{
Bathymetric and Velocimetric Surveys at Highway Bridges Crossing the Missouri and Mississippi Rivers on the Periphery of Missouri, July-August 2018
}

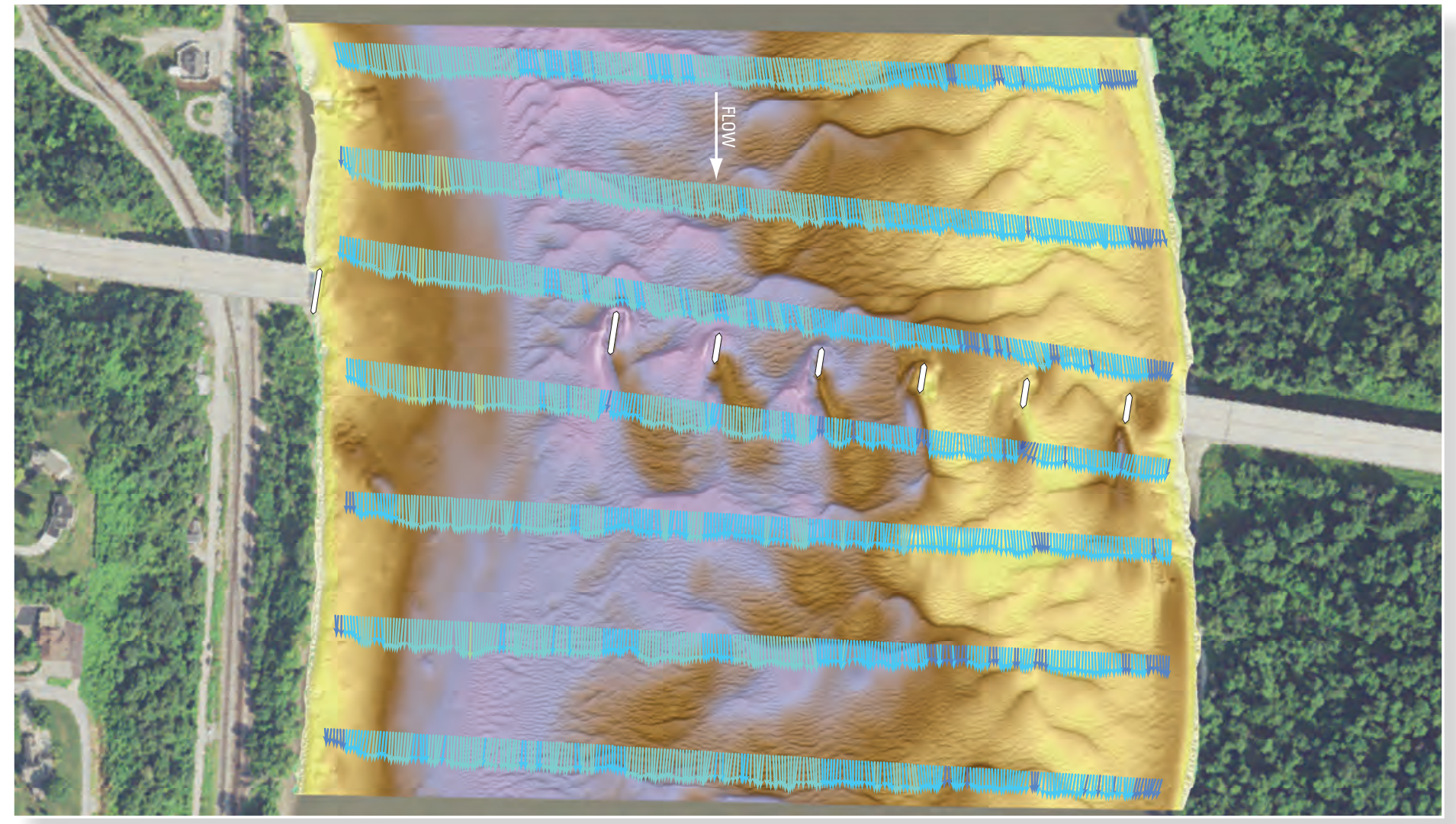

Scientific Investigations Report 2020-5088 
Front Cover: Bathymetry and vertically averaged velocities of the Mississippi River channel near structure A5054 on Interstate 72 at Hannibal, Missouri, on July 18, 2018.

Back Cover: Photograph showing a U.S. Geological Survey boat preparing to survey bathymetry and velocimetry at structure A1700 on Interstate 155 crossing the Mississippi River near Caruthersville, Missouri, on July 26, 2018. 


\section{Bathymetric and Velocimetric Surveys at Highway Bridges Crossing the Missouri and Mississippi Rivers on the Periphery of Missouri, July-August 2018}

By Richard J. Huizinga

Prepared in cooperation with the Missouri Department of Transportation

Scientific Investigations Report 2020-5088 


\title{
U.S. Department of the Interior \\ DAVID BERNHARDT, Secretary
}

\author{
U.S. Geological Survey \\ James F. Reilly II, Director
}

U.S. Geological Survey, Reston, Virginia: 2020

For more information on the USGS - the Federal source for science about the Earth, its natural and living resources, natural hazards, and the environment—visit https://www.usgs.gov or call 1-888-ASK-USGS.

For an overview of USGS information products, including maps, imagery, and publications, visit https://store.usgs.gov/.

Any use of trade, firm, or product names is for descriptive purposes only and does not imply endorsement by the U.S. Government.

Although this information product, for the most part, is in the public domain, it also may contain copyrighted materials as noted in the text. Permission to reproduce copyrighted items must be secured from the copyright owner.

Suggested citation:

Huizinga, R.J., 2020, Bathymetric and velocimetric surveys at highway bridges crossing the Missouri and Mississippi Rivers on the periphery of Missouri, July-August 2018: U.S. Geological Survey Scientific Investigations Report 2020-5088, 100 p., https://doi.org/10.3133/sir20205088.

Associated data for this publication:

Huizinga, R.J., 2020, Bathymetry and velocity data from surveys at highway bridges crossing the Missouri and Mississippi Rivers on the periphery of Missouri, December 2008 through August 2018: U.S. Geological Survey data release, https://doi.org/10.5066/P9WDI9YF.

ISSN 2328-0328 (online) 


\section{Contents}

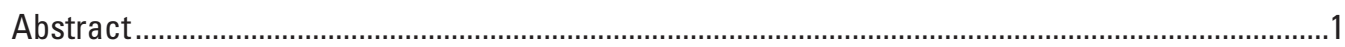

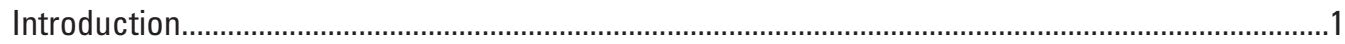

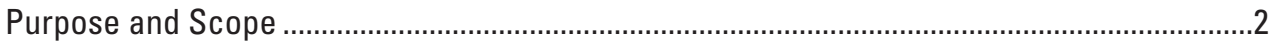

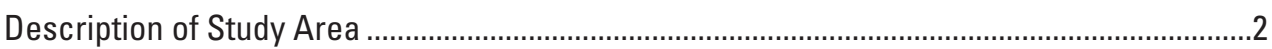

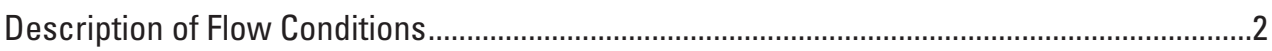

Description of Equipment and Basic Processing ...................................................................

Basic Description of Methods ...........................................................................................

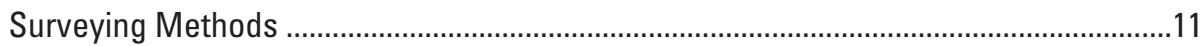

Survey Quality-Assurance/Quality-Control Measures ....................................................11

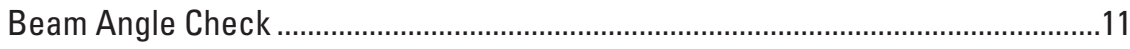

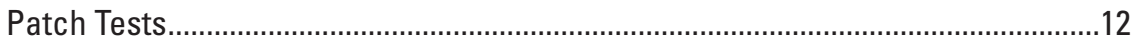

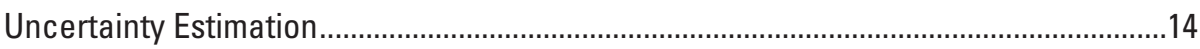

Results of Bathymetric and Velocimetric Surveys...................................................................16

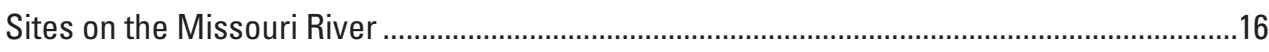

Structure L0098 on U.S. Highway 136 at Brownville, Nebraska....................................17

Dual Bridge Structure A3664 on U.S. Highway 36 at St. Joseph, Missouri.....................32

Sites on the Mississippi River............................................................................................4

Structure A5054 on Interstate 72 at Hannibal, Missouri ..............................................44

Structure L0135 on State Highway 51 at Chester, Illinois.............................................54

Structure A5076 on State Highway 34 at Cape Girardeau, Missouri ...............................64

Structure A1700 on Interstate 155 near Caruthersville, Missouri...................................74

General Findings and Implications ..............................................................................75

Effects of Moderate Flooding Compared to Previous Surveys ........................................75

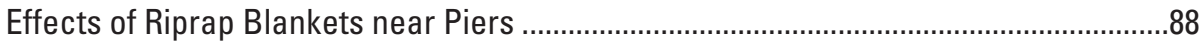

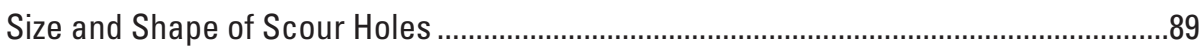

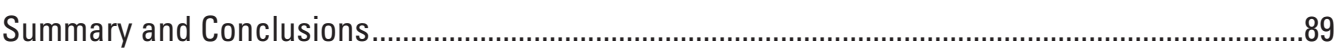

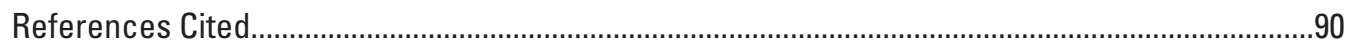

Appendix 1. Shaded Triangulated Irregular Network Images of the Channel and Side of

Pier for Each Surveyed Pier .................................................................................................93

\section{Figures}

1. Maps showing location of highway bridges crossing the Missouri and Mississippi Rivers in and into Missouri, and bathymetric surveys of the Missouri and Mississippi River channels from July 16 to August 13, 2018.

2. Graphs showing unit values of gage height at selected streamflow-gaging

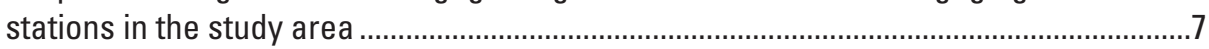

3. Photographs showing the Norbit iWBMSh multibeam echosounder ..............................10

4. Illustration showing generalized effects on data from a multibeam echosounder.........13

5. Map showing total propagated uncertainty of bathymetric data from the Mississippi River channel near structure A1700 on Interstate 155 near Caruthersville, Missouri.

6. Map showing bathymetric survey of the Missouri River channel near structure L0098 on U.S. Highway 136 at Brownville, Nebraska... 
7. Graph showing frequency distribution of bed elevations for bathymetric survey-grid cells in 1-foot elevation bins on the Missouri River near structure L0098 on U.S. Highway 136 at Brownville, Nebraska, on August 13, 2018, compared to previous surveys.

8. Profile showing key features, substructural and superstructural details, and surveyed channel bed of structure L0098 on U.S. Highway 136 over the Missouri River at Brownville, Nebraska

9. Map showing difference between surfaces created from bathymetric surveys of the Missouri River channel near structure L0098 on U.S. Highway 136 at Brownville, Nebraska, on August 13, 2018, and June 3, 2014.

10. Map showing difference between surfaces created from bathymetric surveys of the Missouri River channel near structure L0098 on U.S. Highway 136 at Brownville, Nebraska, on August 13, 2018, and July 13, 2011

11. Map showing bathymetry and vertically averaged velocities of the Missouri River channel near structure L0098 on U.S. Highway 136 at Brownville, Nebraska .......30

12. Map showing bathymetric survey of the Missouri River channel near dual bridge structure A3664 on U.S. Highway 36 at St. Joseph, Missouri .34

13. Graph showing frequency distribution of bed elevations for bathymetric survey-grid cells in 1-foot elevation bins on the Missouri River near dual bridge structure A3664 on U.S. Highway 36 at St. Joseph, Missouri, on July 16, 2018, compared to previous surveys.

14. Profile showing key features, substructural and superstructural details, and surveyed channel bed of dual bridge structure A3664 on U.S. Highway 36 crossing the Missouri River at St. Joseph, Missouri.

15. Map showing difference between surfaces created from bathymetric surveys of the Missouri River channel near dual bridge structure A3664 on U.S. Highway 36 at St. Joseph, Missouri, on July 16, 2018, and June 4, 2014.

16. Map showing difference between surfaces created from bathymetric surveys of the Missouri River channel near dual bridge structure A3664 on U.S. Highway 36 at St. Joseph, Missouri, on July 16, 2018, and July 14, 2011

17. Map showing bathymetry and vertically averaged velocities of the Missouri River channel near dual bridge structure A3664 on U.S. Highway 36 at St. Joseph, Missouri

18. Map showing bathymetric survey of the Mississippi River channel near structure A5054 on Interstate 72 at Hannibal, Missouri.

19. Graph showing frequency distribution of bed elevations for bathymetric survey-grid cells in 1-foot elevation bins on the Mississippi River near structure A5054 on Interstate 72 at Hannibal, Missouri, on July 18, 2018, compared to previous surveys

20. Profile showing key features, substructural and superstructural details, and surveyed channel bed of structure A5054 on Interstate 72 crossing the Mississippi River at Hannibal, Missouri.

21. Map showing difference between surfaces created from bathymetric surveys of the Mississippi River channel near structure A5054 on Interstate 72 at Hannibal, Missouri, on July 18, 2018, and June 5, 2014.

22. Map showing bathymetry and vertically averaged velocities of the Mississippi River channel near structure A5054 on Interstate 72 at Hannibal, Missouri.

23. Map showing bathymetric survey of the Mississippi River channel near structure L0135 on State Highway 51 at Chester, Illinois 
24. Graph showing frequency distribution of bed elevations for bathymetric survey-grid cells in 1-foot elevation bins on the Mississippi River near structure L0135 on State Highway 51 at Chester, Illinois, on July 24, 2018, compared to previous surveys...

25. Profile showing key features, substructural and superstructural details, and surveyed channel bed of structure L0135 on State Highway 51 crossing the Mississippi River at Chester, Illinois.

26. Map showing difference between surfaces created from bathymetric surveys of the Mississippi River near structure L0135 on State Highway 51 at Chester, Illinois, on July 24, 2018, and June 9, 2014.

27. Map showing bathymetry and vertically averaged velocities of the Mississippi River near structure L0135 on State Highway 51 at Chester, Illinois.

28. Map showing bathymetric survey of the Mississippi River channel near structure A5076 on State Highway 34 at Cape Girardeau, Missouri.

29. Graph showing frequency distribution of bed elevations for bathymetric survey-grid cells in 1-foot elevation bins on the Mississippi River near structure A5076 on State Highway 34 at Cape Girardeau, Missouri, on July 25, 2018, compared to previous surveys

30. Profile showing key features, substructural and superstructural details, and surveyed channel bed of structure A5076 on State Highway 34 crossing the Mississippi River at Cape Girardeau, Missouri

31. Map showing difference between surfaces created from bathymetric surveys of the Mississippi River channel near structure A5076 on State Highway 34 at Cape Girardeau, Missouri, on July 25, 2018, and June 10, 2014

32. Map showing bathymetry and vertically averaged velocities of the Mississippi River channel near structure A5076 on State Highway 34 at Cape Girardeau, Missouri.

33. Map showing bathymetric survey of the Mississippi River channel near structure A1700 on Interstate 155 near Caruthersville, Missouri

34. Graph showing frequency distribution of bed elevations for bathymetric survey-grid cells in 1-foot elevation bins on the Mississippi River near structure A1700 on Interstate 155 near Caruthersville, Missouri, on July 26, 2018, compared to previous surveys

35. Profile showing key features, substructural and superstructural details, and surveyed channel bed of structure A1700 on Interstate 155 crossing the Mississippi River near Caruthersville, Missouri.

36. Map showing difference between surfaces created from bathymetric surveys of the Mississippi River channel near structure A1700 on Interstate 155 near Caruthersville, Missouri, on July 26, 2018, and June 11, 2014

37. Map showing difference between surfaces created from bathymetric surveys of the Mississippi River channel near structure A1700 on Interstate 155 near Caruthersville, Missouri, on July 26, 2018, and May 5, 2011

38. Map showing difference between surfaces created from bathymetric surveys of the Mississippi River channel near structure A1700 on Interstate 155 near Caruthersville, Missouri, on July 26, 2018, and December 10, 2008 . .84

39. Map showing bathymetry and vertically averaged velocities of the Mississippi River channel near structure A1700 on Interstate 155 near Caruthersville, Missouri ....86 


\section{Tables}

1. Highway bridges crossing the Missouri River in and into Missouri, in downstream order

2. Highway bridges crossing the Mississippi River into Missouri, in downstream order

3. Bridge and survey information, and selected channel-bed elevations from surveys on the Missouri and Mississippi Rivers on the periphery of Missouri, from July 16 to August 13, 2018

4. Results of a beam angle check from two check lines over a reference surface at Sugar Creek Lake near Moberly, Missouri, on September 6, 2018.

5. Patch test results at various locations from June 28 to July 24,2018

6. Total propagated uncertainty results for bathymetric data at a 1.64-foot grid spacing from surveys on the Missouri and Mississippi Rivers on the periphery of Missouri, from July 16 to August 13, 2018

7. Results near piers from surveys on the Missouri and Mississippi Rivers on the periphery of Missouri, from July 16 to August 13, 2018.

8. Summary information and bathymetric surface difference statistics from surveys on the Missouri and Mississippi Rivers on the periphery of Missouri, from July 16 to August 13, 2018, and previous surveys.

\section{Conversion Factors}

U.S. customary units to International System of Units

\begin{tabular}{lcl}
\hline \multicolumn{1}{c}{ Multiply } & By & \multicolumn{1}{c}{ To obtain } \\
\hline foot (ft) & Length & meter $(\mathrm{m})$ \\
mile (mi) & 0.3048 & kilometer $(\mathrm{km})$ \\
\hline & 1.609 & \\
\hline cubic yard $\left(\mathrm{yd}^{3}\right)$ & Volume & cubic meter $\left(\mathrm{m}^{3}\right)$ \\
\hline & 0.7646 & \\
\hline foot per second $(\mathrm{ft} / \mathrm{s})$ & Flow rate & meter per second $(\mathrm{m} / \mathrm{s})$ \\
cubic foot per second $(\mathrm{ft} 3 / \mathrm{s})$ & 0.3048 & cubic meter per second $\left(\mathrm{m}^{3} / \mathrm{s}\right)$ \\
\hline
\end{tabular}

\section{Datum}

Vertical coordinate information is referenced to the North American Vertical Datum of 1988 (NAVD 88).

Horizontal coordinate information is referenced to the North American Datum of 1983 (NAD 83). 


\section{Supplemental Information}

In this report, the words "left" and "right" generally refer to directions that would be reported by an observer facing downstream.

Distance on the Missouri River is given in river miles (RMs) upstream from the confluence with the Mississippi River at St. Louis, Missouri, at river mile 195.2 of the Upper Mississippi River.

Frequency is given in kilohertz $(\mathrm{kHz})$.

Data were collected, processed, and output in the International System of Units, and converted to U.S. customary units for presentation in the report at the request and for the convenience of the cooperator.

\section{Abbreviations}

$\begin{array}{ll}\text { ADCP } & \text { acoustic Doppler current profiler } \\ \text { CUBE } & \text { Combined Uncertainty and Bathymetry Estimator } \\ \text { GNSS } & \text { Global Navigation Satellite System } \\ \text { IHO } & \text { International Hydrographic Organization } \\ \text { IMU } & \text { inertial measurement unit } \\ \text { INS } & \text { inertial navigation system } \\ \text { MBES } & \text { multibeam echosounder } \\ \text { MBMS } & \text { multibeam echosounder mapping system } \\ \text { MMS } & \text { Mobile Mapping Suite } \\ \text { MoDOT } & \text { Missouri Department of Transportation } \\ \text { POS MV } & \text { Position Orientation Solution for Marine Vessels } \\ \text { RM } & \text { river mile } \\ \text { RTK } & \text { real-time kinematic } \\ \text { SBET } & \text { smoothed best estimate of trajectory } \\ \text { sonar } & \text { sound navigation and ranging } \\ \text { TIN } & \text { triangulated irregular network } \\ \text { TPU } & \text { total propagated uncertainty } \\ \text { USGS } & \text { U.S. Geological Survey } \\ & \end{array}$





\title{
Bathymetric and Velocimetric Surveys at Highway Bridges Crossing the Missouri and Mississippi Rivers on the Periphery of Missouri, July-August 2018
}

\author{
By Richard J. Huizinga
}

\section{Abstract}

Bathymetric and velocimetric data were collected by the U.S. Geological Survey, in cooperation with the Missouri Department of Transportation, near 7 bridges at 6 highway crossings of the Missouri and Mississippi Rivers on the periphery of the State of Missouri from July 16 to August 13, 2018. A multibeam echosounder mapping system was used to obtain channel-bed elevations for river reaches about 1,640 feet longitudinally and generally extending laterally across the active channel from bank to bank during moderate flood-flow conditions. These surveys indicate the channel conditions at the time of the surveys and provide characteristics of scour holes that may be useful in the development of predictive guidelines or equations for scour holes. These data also may be useful to the Missouri Department of Transportation as a low to moderate flood-flow comparison to help assess the bridges for stability and integrity issues with respect to bridge scour during floods.

Bathymetric data were collected around every pier that was in water, except those at the edge of water, and scour holes were present at most piers for which bathymetry could be obtained, except those on banks, on bedrock, or surrounded by riprap. Occasionally, the scour hole near a pier was difficult to discern from nearby bed features. The observed scour holes at the surveyed bridges were generally examined with respect to shape and depth.

Although partial exposure of substructural support elements was observed at several piers, at most sites the exposure likely can be considered minimal compared to the overall substructure that remains buried in bed material at these piers. The notable exceptions are piers 12 and 13 at structure L0135 on State Highway 51 at Chester, Illinois, at which the bedrock material was fully exposed around the piers.

The presence of riprap blankets, pier size and nose shape, and alignment to flow had a substantial effect on the size of the scour hole observed for a given pier. Piers that were surrounded by riprap blankets had scour holes that were substantially smaller (to nonexistent) compared to piers at which no rock or riprap were present. Narrow piers having round or sharp noses that were aligned with flow often had scour holes that were difficult to discern from nearby bed features, whereas piers having wide or blunt noses resulted in larger, deeper scour holes. Several of the structures had piers that were skewed to primary approach flow, and scour holes near these piers generally displayed deposition on the leeward side of the pier and greater depth on the side of the pier with impinging flow.

\section{Introduction}

Scour in alluvial channels is the removal of channelbed and bank material by flowing water and is the leading cause of bridge failures in the United States (Richardson and Davis, 2001). Scour at a bridge site is the result of short- and long-term geomorphic processes and the local effects caused by elements of the structure in or adjacent to the waterway (Richardson and Davis, 2001; Huizinga and Rydlund, 2004). Because the effects of scour can be severe and dangerous, bridges and other structures over waterways are routinely assessed and inspected. Scour processes can be exacerbated during high-flow conditions because velocity and depth typically increase.

The Missouri Department of Transportation (MoDOT) is responsible for most of the transportation infrastructure in the State. A part of this responsibility is fulfilled through periodic inspections of highway structures, including bridges that span waterways. At most of these structures, all or most of the structure can be fully inspected from land or from personnel lift trucks deployed from the roadway of the structure; however, for structures over primary waterways, such as the Missouri and Mississippi Rivers, inspection of the part of the bridge that is underwater requires a different approach.

The U.S. Geological Survey (USGS), in cooperation with MoDOT, began assessing scour at waterway crossings throughout the State in 1991 (Huizinga and Rydlund, 2004). In 2007, the USGS, in cooperation with MoDOT, began determining channel bathymetry and monitoring bridges for scour using single-beam echosounders and a multibeam echosounder mapping system (MBMS; Rydlund, 2009; Huizinga, 2010, 2011, 2012, 2013, 2014, 2015, 2016, 2017a, b, 2020a, b, c, 
d; Huizinga and others, 2010). The MBMS has proven to be a useful tool not only in determining channel bathymetry but also in providing a medium- to high-resolution representation of bridge structural elements below the water line. In March 2010, 9 highway bridges at 7 crossings over the Missouri River near Kansas City, Missouri, were assessed using the MBMS (Huizinga, 2010); and in October 2010, 12 highway bridges at 7 crossings over the Missouri and Mississippi Rivers near St. Louis, Mo., were assessed (Huizinga, 2011). During high-flow conditions in JuneAugust 2011, many of the highway bridges and several of the railroad bridges along the entirety of the Missouri River downstream from Montana were assessed (Densmore and others, 2013; Dietsch and others, 2014), including the 37 highway bridges (at 28 crossings) over the Missouri River in and into Missouri (Huizinga, 2012). In April and May 2013, 10 highway bridges at 9 crossings over the Missouri River between Kansas City and St. Louis, Mo., were assessed as part of more routine, nonflood surveys at bridge sites in and into Missouri (Huizinga, 2014). In June 2014, 8 highway bridges at 7 crossings over the Missouri and Mississippi Rivers on the periphery of Missouri also were assessed as part of the routine, nonflood surveys at bridge sites (Huizinga, 2015).

Starting in 2015, a second round of routine, nonflood surveys at the highway bridges across the Missouri and Mississippi Rivers throughout Missouri commenced, beginning with the Kansas City area bridges in June 2015 (Huizinga, 2016), continuing with St. Louis in May 2016 (Huizinga, 2017a, b) and the bridges between Kansas City and St. Louis in May 2017 (Huizinga, 2020a, b, c, d). The study detailed in this report is the continuation of this second round of routine, nonflood surveys at the highway bridges across the Missouri and Mississippi Rivers on the periphery of Missouri, except the bridge at Louisiana, Mo., which was being replaced in 2018 (fig. 1). Therefore, the study detailed in this report includes 7 bridges at 6 crossings (tables 1 and 2).

\section{Purpose and Scope}

The purpose of this report is to document the results of bathymetric and velocimetric surveys completed July 16 to August 13, 2018, of the Missouri and Mississippi River channel near 7 highway bridges at 6 crossings on the periphery of Missouri (fig. 1; tables 1 and 2) using an MBMS and an acoustic Doppler current profiler (ADCP). Equipment and methods used and results obtained are described. The results obtained from the bathymetric and velocimetric surveys of the channel document the channel-bed conditions and velocity distribution at the time of the surveys and provide characteristics of scour holes that may be useful in developing predictive guidelines or equations for scour holes. These data also may be used by MoDOT as a low to moderate flood-flow comparison to help assess the bridges for stability and integrity issues with respect to bridge scour. Comparison of results to previous surveys at the sites (Huizinga, 2012, 2015) also are provided.

\section{Description of Study Area}

The generalized study area for this report covers approximately 90 miles (mi) of the lower Missouri River in the northwestern part of Missouri upstream from Kansas City, Mo., and approximately $300 \mathrm{mi}$ of the upper Mississippi River (upstream from the confluence with the Ohio River) and $115 \mathrm{mi}$ of the lower Mississippi River (downstream from the confluence with the Ohio River) along the eastern border of Missouri, excluding the greater St. Louis, Mo., area (fig. 1). On the Missouri River, the highway crossings at Brownville, Nebraska, and St. Joseph, Mo., were examined as part of this study (fig. 1, table 1). On the Mississippi River, the highway crossings at Hannibal, Mo.; Chester, Illinois; Cape Girardeau, Mo.; and near Caruthersville, Mo., were examined (fig. 1, table 2). The site numbering sequence used in previous studies on the Missouri and Mississippi Rivers (Huizinga, 2012, 2015) is used in this report for consistency and comparability.

\section{Description of Flow Conditions}

Both the Missouri and Mississippi Rivers were receding from a flood peak in mid- to late June when the sites were surveyed from July 16 to August 13, 2018 (fig. 2). A survey at the upstream-most site on the Missouri River, structure L0098 on U.S. Highway 136 at Brownville, Nebr. (site 1, fig. 1) was attempted on July 17, 2018, but the water-surface elevation was such that there was no suitable water access at the site. Therefore, this upstream-most site was surveyed last, on August 13, after a prolonged recession from out-of-bank high flow (fig. 2A). The streamflow on the Missouri River was approximately 77,800 cubic feet per second ( $\mathrm{ft} 3 / \mathrm{s})$, as measured at the site (table 3 ), slightly more than the streamflow of 73,500 ft $3 / \mathrm{s}$ obtained from the rating curve for the USGS streamflow-gaging station (hereinafter referred to as "streamgage") on the Missouri River upstream from the study area at Nebraska City, Nebr. (station 06807000; U.S. Geological Survey, 2020; fig. 1), and also slightly more than the streamflow of $76,040 \mathrm{ft} 3 / \mathrm{s}$ obtained from the rating curve for the USGS streamgage downstream from the study area at Rulo, Nebr. (station 06813500; U.S. Geological Survey, 2020; fig. 1). This streamflow has a daily exceedance of about 4.7 percent, and is slightly less than the 50-percent annual exceedance probability (2-year recurrence interval) flood flow of 88,000 ft $3 / \mathrm{s}$ at Nebraska City (table F-49 in U.S. Army Corps of Engineers, 2004a).

The Missouri River was earlier in the flood-peak recession at the time of the first survey on July 16, 2018, at structure A3664 on U.S. Highway 36 at St. Joseph, Mo. (site 2; figs. 1, 2A). The streamflow on the Missouri River at St. Joseph was measured as approximately 96,100 ft $3 / \mathrm{s}$ (site 2 , table 3 ), which is slightly greater than the gaged streamflow of $91,400 \mathrm{ft} 3 / \mathrm{s}$ obtained from the rating curve for the streamgage at St. Joseph (station 06818000; U.S. Geological Survey, 2020; fig. 1). The streamflow has a daily exceedance 

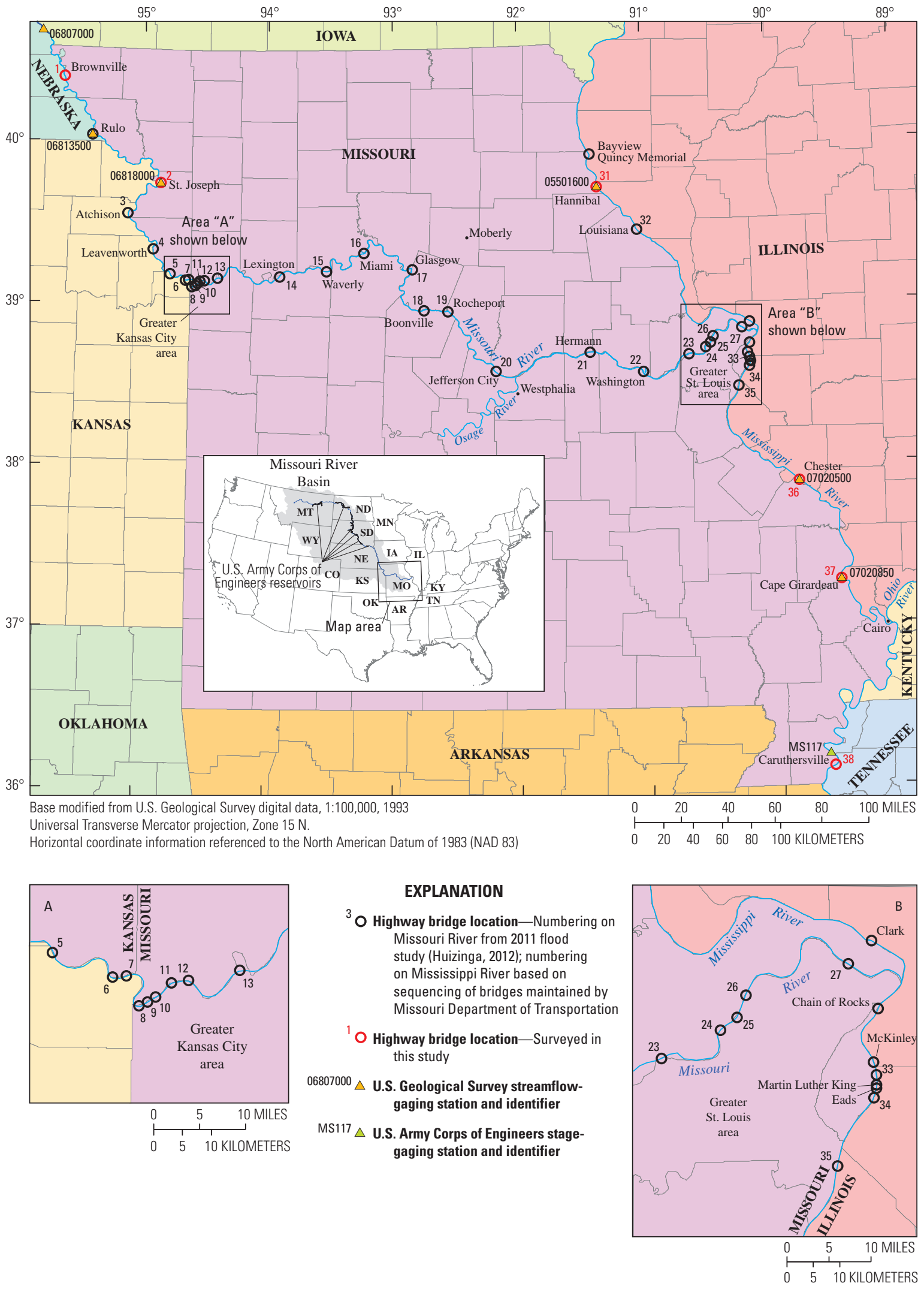

Figure 1. Location of highway bridges crossing the Missouri and Mississippi Rivers in and into Missouri, and bathymetric surveys of the Missouri and Mississippi River channels from July 16 to August 13, 2018. 
Table 1. Highway bridges crossing the Missouri River in and into Missouri, in downstream order.

[MoDOT, Missouri Department of Transportation; Mo., Missouri; US, U.S. highway; --, not known/applicable; NDOR, Nebraska Department of Roads; Nebr., Nebraska; W, westbound; Kans., Kansas; E, east-

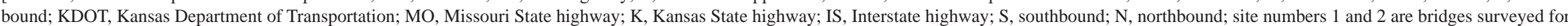
the study]

\begin{tabular}{|c|c|c|c|c|c|c|c|c|c|}
\hline $\begin{array}{c}\text { Site } \\
\text { number } \\
\text { (fig. 1) }\end{array}$ & $\begin{array}{l}\text { Primary } \\
\text { agency }\end{array}$ & $\begin{array}{l}\text { Structure } \\
\text { number }\end{array}$ & Local name & County & Route & $\begin{array}{l}\text { River } \\
\text { milea }\end{array}$ & $\begin{array}{l}\text { Surveyed as } \\
\text { part of this } \\
\text { study }\end{array}$ & Remarks & Figures \\
\hline \multicolumn{10}{|c|}{ Upstream from Kansas City } \\
\hline 1 & MoDOT & L0098 & Brownville & Atchison, Mo. & US 136 & 535.3 & Yes & -- & $\begin{array}{c}1,6,7,8,9,10 \\
11,1.1\end{array}$ \\
\hline-- & NDOR & A7698 & Rulo & Richardson, Nebr. & US 159 & 498.1 & No & -- & 1 \\
\hline \multirow{2}{*}{2} & \multirow{2}{*}{ MoDOT } & A3664 W & St. Joseph & Buchanan, Mo. & US $36 \mathrm{~W}$ & \multirow{2}{*}{447.9} & Yes & Dual bridge crossing & $\begin{array}{c}1,12,13,14,15 \\
16,17,1.2\end{array}$ \\
\hline & & A3664 E & St. Joseph & Doniphan, Kans. & US $36 \mathrm{E}$ & & Yes & Dual bridge crossing & $\begin{array}{c}1,12,13,14,15 \\
16,17,1.2\end{array}$ \\
\hline 3 & KDOT & $\begin{array}{l}\text { 59-3-16.38 } \\
(013)\end{array}$ & Atchison & Atchison, Kans. & US 59 & 422.5 & No & -- & 1 \\
\hline 4 & KDOT & $\begin{array}{l}92-52-18.48 \\
(026)\end{array}$ & Leavenworth & Leavenworth, Kans. & MO 92/K 92 & 397.5 & No & -- & 1 \\
\hline \multicolumn{10}{|c|}{ Greater Kansas City area } \\
\hline \multirow{2}{*}{5} & \multirow{2}{*}{ KDOT } & $\begin{array}{l}\text { 435-105-11.97 } \\
\quad(235)\end{array}$ & Parkville & Platte, Mo. & IS $435 \mathrm{~S}$ & \multirow{2}{*}{383.4} & No & $\begin{array}{l}\text { Dual bridge crossing } \\
\text { with 435-105-11.98 } \\
\text { (240) }\end{array}$ & 1 \\
\hline & & $\begin{array}{l}\text { 435-105-11.98 } \\
\quad(240)\end{array}$ & Parkville & Wyandotte, Kans. & IS $435 \mathrm{~N}$ & & No & $\begin{array}{l}\text { Dual bridge crossing } \\
\text { with 435-105-11.97 } \\
\text { (235) }\end{array}$ & 1 \\
\hline 6 & MoDOT & A1800 & Riverside & Platte, Mo. & IS 635 & 374.1 & No & -- & 1 \\
\hline 7 & MoDOT & A8340 & Fairfax & Platte, Mo. & US 69 & 372.6 & No & $\begin{array}{l}\text { Replaced K0456/A0450 } \\
\text { in } 2016\end{array}$ & 1 \\
\hline 8 & MoDOT & A4649 & Buck O'Neil & Clay, Mo. & US 169 & 366.2 & No & -- & 1 \\
\hline 9 & MoDOT & A 4060 & Heart of America & Clay, Mo. & MO 9 & 365.5 & No & -- & 1 \\
\hline 10 & MoDOT & A7650 & Christopher Bond & Clay, Mo. & IS 35 & 364.7 & No & -- & 1 \\
\hline 11 & MoDOT & A5817 & Chouteau & Clay, Mo. & MO 269 & 362.3 & No & -- & 1 \\
\hline 12 & MoDOT & A0767 & Randolph & Clay, Mo. & IS 435 & 360.3 & No & -- & 1 \\
\hline \multirow{2}{*}{13} & \multirow{2}{*}{ MoDOT } & A 4757 & Courtney & Jackson, Mo. & MO $291 \mathrm{~S}$ & \multirow{2}{*}{352.7} & No & $\begin{array}{l}\text { Dual bridge crossing } \\
\text { with L0568 }\end{array}$ & 1 \\
\hline & & L0568 & Courtney & Jackson, Mo. & MO $291 \mathrm{~N}$ & & No & $\begin{array}{l}\text { Dual bridge crossing } \\
\text { with A4757 }\end{array}$ & 1 \\
\hline
\end{tabular}


Table 1. Highway bridges crossing the Missouri River in and into Missouri, in downstream order.-Continued

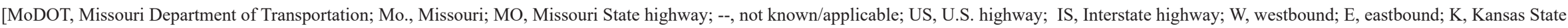
highway; S, southbound; N, northbound; site numbers 1 and 2 are bridges surveyed for the study]

\begin{tabular}{|c|c|c|c|c|c|c|c|c|c|}
\hline $\begin{array}{c}\text { Site } \\
\text { number } \\
\text { (fig. 1) }\end{array}$ & $\begin{array}{l}\text { Primary } \\
\text { agency }\end{array}$ & $\begin{array}{l}\text { Structure } \\
\text { number }\end{array}$ & Local name & County & Route & $\begin{array}{l}\text { River } \\
\text { milea }\end{array}$ & $\begin{array}{c}\text { Surveyed as } \\
\text { part of this } \\
\text { study }\end{array}$ & Remarks & Figures \\
\hline \multicolumn{10}{|c|}{ Between Kansas City and St. Louis } \\
\hline 14 & MoDOT & A5664 & Lexington & Ray, Mo. & MO 13 & 314.9 & No & -- & 1 \\
\hline 15 & MoDOT & A5910 & Waverly & Lafayette, Mo. & US 24 & 293.2 & No & -- & 1 \\
\hline 16 & MoDOT & K0999 & Miami & Carroll, Mo. & MO 41 & 262.6 & No & -- & 1 \\
\hline 17 & MoDOT & G0069 & Glasgow & Saline, Mo. & MO 240 & 226.3 & No & -- & 1 \\
\hline 18 & MoDOT & A4574 & Boonville & Cooper, Mo. & US 40 & 196.6 & No & -- & 1 \\
\hline 19 & MoDOT & L0962 & Rocheport & Boone, Mo. & IS 70 & 185.1 & No & -- & 1 \\
\hline \multirow{2}{*}{20} & \multirow{2}{*}{ MoDOT } & L0550 & Jefferson City & Callaway, Mo. & US $54 \mathrm{~W}$ & \multirow{2}{*}{143.9} & No & $\begin{array}{l}\text { Dual bridge crossing } \\
\text { with A4497 }\end{array}$ & 1 \\
\hline & & A4497 & Jefferson City & Cole, Mo. & US $54 \mathrm{E}$ & & No & $\begin{array}{l}\text { Dual bridge crossing } \\
\text { with L0550 }\end{array}$ & 1 \\
\hline 21 & MoDOT & A6288 & Hermann & Montgomery, Mo. & MO 19 & 97.9 & No & -- & 1 \\
\hline 22 & MoDOT & A8141 & Washington & Franklin, Mo. & MO 47 & 67.6 & No & Replaced K0969 in 2018 & 1 \\
\hline \multicolumn{10}{|c|}{ Greater St. Louis area } \\
\hline \multirow{2}{*}{23} & \multirow{2}{*}{ MoDOT } & A7577 & Daniel Boone & St. Charles, Mo. & US $40 \mathrm{E}$ & \multirow{2}{*}{43.9} & No & $\begin{array}{l}\text { Dual bridge crossing } \\
\text { with A4017 }\end{array}$ & 1 \\
\hline & & A4017 & Daniel Boone & St. Louis, Mo. & US $40 \mathrm{~W}$ & & No & $\begin{array}{l}\text { Dual bridge crossing } \\
\text { with A7577 }\end{array}$ & 1 \\
\hline \multirow{2}{*}{24} & \multirow{2}{*}{ MoDOT } & A5585 E & Page Avenue & St. Charles, Mo. & MO $364 \mathrm{E}$ & \multirow{2}{*}{32.7} & No & Dual bridge crossing & 1 \\
\hline & & A5585 W & Page Avenue & St. Louis, Mo. & MO 364 W & & No & Dual bridge crossing & 1 \\
\hline \multirow{2}{*}{25} & \multirow{2}{*}{ MoDOT } & A3292 & Blanchette & St. Charles, Mo. & IS $70 \mathrm{E}$ & \multirow{2}{*}{29.6} & No & $\begin{array}{l}\text { Dual bridge crossing } \\
\text { with L0561 }\end{array}$ & 1 \\
\hline & & L0561 & Blanchette & St. Louis, Mo. & IS $70 \mathrm{~W}$ & & No & $\begin{array}{l}\text { Dual bridge crossing } \\
\text { with A3292 }\end{array}$ & 1 \\
\hline \multirow{2}{*}{26} & \multirow{2}{*}{ MoDOT } & A4557 E & Discovery & St. Charles, Mo. & MO $370 \mathrm{E}$ & \multirow{2}{*}{27.0} & No & Dual bridge crossing & 1 \\
\hline & & A4557 W & Discovery & St. Louis, Mo. & MO $370 \mathrm{~W}$ & & No & Dual bridge crossing & 1 \\
\hline 27 & MoDOT & A3047 & Lewis \& Clark & St. Charles, Mo. & US 67 & 8.1 & No & -- & 1 \\
\hline
\end{tabular}

aRiver mile is the distance upstream from the confluence of the Missouri River with the Mississippi River at St. Louis, Mo. (fig. 1). 
Table 2. Highway bridges crossing the Mississippi River into Missouri, in downstream order.

[--, not known/applicable; IDOT, Illinois Department of Transportation; Ill., Illinois; US, U.S. highway; W, westbound; E, eastbound; MoDOT, Missouri Department of Transportation; Mo., Missouri; IS, Interstate highway; K, Kansas State highway; MO, Missouri State highway; S, southbound; N, northbound; site numbers 31 and 36-38 are bridges surveyed for this study]

\begin{tabular}{|c|c|c|c|c|c|c|c|c|c|}
\hline $\begin{array}{c}\text { Site } \\
\text { number } \\
\text { (fig. 1) }\end{array}$ & $\begin{array}{l}\text { Primary } \\
\text { agency }\end{array}$ & $\begin{array}{l}\text { Structure } \\
\text { number }\end{array}$ & Local name & County & Route & $\begin{array}{l}\text { River } \\
\text { milea }\end{array}$ & $\begin{array}{c}\text { Surveyed as } \\
\text { part of this } \\
\text { study }\end{array}$ & Remarks & Figures \\
\hline \multicolumn{10}{|c|}{ Upstream from St. Louis } \\
\hline-- & IDOT & A 4274 & Bayview & Adams, Ill. & US $24 \mathrm{~W}$ & 327.1 & No & -- & 1 \\
\hline-- & IDOT & L0099 & Quincy Memorial & Marion, Mo. & US 24 E & 327.0 & No & -- & 1 \\
\hline 31 & MoDOT & A5054 & Hannibal & Marion, Mo. & IS 72 & 309.5 & Yes & -- & $\begin{array}{c}1,18,19,20,21,22,1.3, \\
1.4\end{array}$ \\
\hline 32 & MoDOT & A8504 & Louisiana & Pike, Mo. & US 54 & 283.2 & No & Replaced K0932 in 2019 & 1 \\
\hline \multicolumn{10}{|c|}{ Greater St. Louis area } \\
\hline-- & IDOT & A4278 & Clark & St. Charles, Mo. & US 67 & 202.6 & No & -- & 1 \\
\hline-- & IDOT & A0890 & Chain of Rocks & St. Louis City, Mo. & IS 270 & 190.8 & No & -- & 1 \\
\hline-- & IDOT & -- & McKinley & St. Louis City, Mo. & -- & 182.6 & No & -- & 1 \\
\hline 33 & MoDOT & A6500 & $\begin{array}{l}\text { Stan Musial Veterans } \\
\text { Memorial }\end{array}$ & St. Louis City, Mo. & IS 70 & 181.2 & No & -- & 1 \\
\hline-- & IDOT & A4856 & Martin Luther King & St. Louis City, Mo. & MO 799 & 180.2 & No & -- & 1 \\
\hline-- & St. Louis & -- & Eads & St. Louis City, Mo. & -- & 180.0 & No & -- & 1 \\
\hline 34 & MoDOT & A1500 & Poplar Street & St. Louis City, Mo. & IS 55 & 179.2 & No & -- & 1 \\
\hline \multirow{2}{*}{35} & \multirow{2}{*}{ MoDOT } & A4936 & Jefferson Barracks & \multirow{2}{*}{ St. Louis, Mo. } & IS $255 \mathrm{~S}$ & \multirow{2}{*}{168.8} & No & $\begin{array}{l}\text { Dual bridge crossing } \\
\text { with A1850 }\end{array}$ & 1 \\
\hline & & A1850 & Jefferson Barracks & & IS $255 \mathrm{~N}$ & & No & $\begin{array}{l}\text { Dual bridge crossing } \\
\text { with A4936 }\end{array}$ & 1 \\
\hline \multicolumn{10}{|c|}{ Downstream from St. Louis } \\
\hline 36 & MoDOT & L0135 & Chester & Perry, Ill. & MO 51 & 109.9 & Yes & -- & $1,23,24,25,26,27,1.5$ \\
\hline 37 & MoDOT & A5076 & $\begin{array}{l}\text { Bill Emerson } \\
\text { Memorial }\end{array}$ & Cape Girardeau, Mo. & MO 34 & 51.5 & Yes & -- & $1,28,29,30,31,32,1.6$ \\
\hline-- & IDOT & A2000 & Cairo I-57 & Mississippi, Mo. & IS 57 & 7.5 & No & -- & 1 \\
\hline-- & IDOT & K0950 & Cairo Mississippi & Mississippi, Mo. & US 60 & 1.4 & No & -- & 1 \\
\hline 38 & MoDOT & A1700 & Caruthersville & Pemiscot, Mo. & IS 155 & 838.9 & Yes & -- & $\begin{array}{c}1,5,33,34,35,36,37 \\
38,39,1.7,1.8\end{array}$ \\
\hline
\end{tabular}

aExcept for site 38, river mile is the distance upstream on the Upper Mississippi River, starting at the confluence with the Ohio River at Cairo, Ill. (fig. 1), at river mile 953.5 of the Lower Mississippi River. For site 38, river mile is the distance upstream on the Lower Mississippi River, starting at the mouth of the Mississippi River at the Gulf of Mexico. 


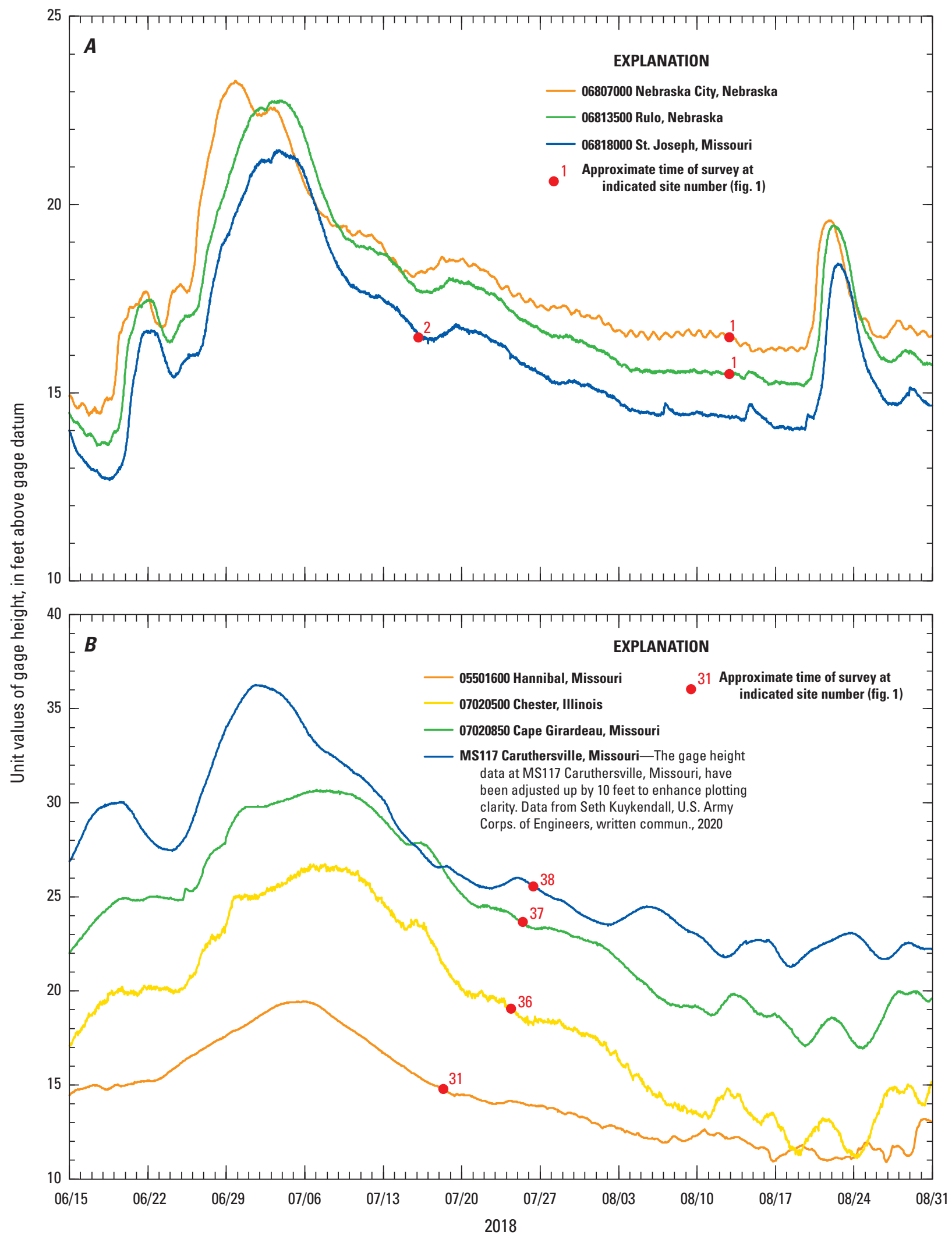

Figure 2. Unit values of gage height at selected streamflow-gaging stations in the study area. $A$, Missouri River upstream from Kansas City, Missouri, at a 30-minute interval. $B$, Mississippi River along the eastern border of Missouri at a 1-hour interval, from June 15 to August 31, 2018 (U.S Geological Survey, 2020). 
Table 3. Bridge and survey information, and selected channel-bed elevations from surveys on the Missouri and Mississippi Rivers on the periphery of Missouri, from July 16 to August 13, 2018.

[MoDOT, Missouri Department of Transportation; ADCP, acoustic Doppler current profiler; ft $3 / \mathrm{s}$, cubic feet per second; ft, feet; US, U.S. highway; E, east-bound; W, west-bound; MO, Missouri State highway; IS, Interstate highway; all elevations are in feet above the North American Vertical Datum of 1988]

\begin{tabular}{|c|c|c|c|c|c|c|c|c|c|c|}
\hline \multirow{2}{*}{$\begin{array}{c}\text { Site } \\
\text { number } \\
\text { (fig. 1) }\end{array}$} & \multirow{2}{*}{$\begin{array}{c}\text { MoDOT structure } \\
\text { number }\end{array}$} & \multirow{2}{*}{ Survey date } & \multirow{2}{*}{ Route } & \multirow{2}{*}{$\begin{array}{l}\text { River } \\
\text { milea }\end{array}$} & \multirow{2}{*}{$\begin{array}{c}\text { Streamflow } \\
\text { from ADCP } \\
\text { measurements } \\
\left(\mathrm{ft}^{3} / \mathrm{s}\right)\end{array}$} & \multirow{2}{*}{$\begin{array}{l}\text { Average water- } \\
\text { surface elevation in } \\
\text { vicinity of bridge } \\
\text { (ft) }\end{array}$} & \multirow{2}{*}{$\begin{array}{c}\text { Average } \\
\text { channel- } \\
\text { bed } \\
\text { elevationc } \\
\text { (ft) }\end{array}$} & \multicolumn{2}{|c|}{$\begin{array}{l}\text { Approximate elevation of the } \\
\text { indicated percentile of the } \\
\text { bathymetric data }\end{array}$} & \multirow{2}{*}{$\begin{array}{l}\text { Approximate } \\
\text { minimum } \\
\text { channel } \\
\text { elevationd } \\
\text { (ft) }\end{array}$} \\
\hline & & & & & & & & $\begin{array}{c}\text { 5th } \\
\text { percentile } \\
\text { (ft) }\end{array}$ & $\begin{array}{c}\text { 95th } \\
\text { percentile } \\
\text { (ft) }\end{array}$ & \\
\hline 1 & L0098 & 08/13/18 & US 136 & 535.3 & 77,800 & 892.3 & 869.2 & 862.8 & 881.0 & 845 \\
\hline 2 & A3664 E \& W & 07/16/18 & US 36 & 447.9 & 96,100 & 805.8 & 782.8 & 774.5 & 794.8 & 753 \\
\hline 31 & A5054 & 07/18/18 & IS 72 & 309.5 & 173,000 & 464.0 & 438.8 & 429.5 & 448.6 & 423 \\
\hline 36 & L0135 & 07/24/18 & MO 51 & 109.9 & 290,000 & 360.4 & 329.9 & 316.8 & 345.6 & 306 \\
\hline 37 & A5076 & $07 / 25 / 18$ & MO 34 & 51.5 & 282,000 & 328.2 & 292.4 & 277.9 & 313.7 & 270 \\
\hline 38 & A1700 & 07/26/18 & IS 155 & 838.9 & 420,000 & 245.9 & 199.7 & 178.5 & 220.0 & 164 \\
\hline
\end{tabular}

aFor sites 1-2, river mile is the distance upstream on the Lower Missouri River, starting at the confluence with the Mississippi River at St. Louis, Missouri. (fig. 1), at river mile 195.2 of the Upper Mississippi River. For sites 31-37, river mile is the distance upstream on the Upper Mississippi River, starting at the confluence with the Ohio River at Cairo, Illinois (fig. 1), at river mile 953.5 of the Lower Mississippi River. For site 38, river mile is the distance upstream on the Lower Mississippi River, starting at the mouth at the Gulf of Mexico.

bThe average streamflow obtained while making the various velocity transects. The reported value is the streamflow computed using Global Navigation Satellite System (GNSS) essential fix GGA data string as the reference, as described in the "Surveying Methods" section of the text.

cThe statistical average of the surveyed channel-bed elevations.

dThe minimum channel-bed elevation, not necessarily in any scour holes near the bridge. 
of approximately 4.9 percent, and is slightly less than the 2-percent annual exceedance probability (2-year recurrence interval) flood flows of $109,000 \mathrm{ft}^{3} / \mathrm{s}$ at St. Joseph (plate E-20 in U.S. Army Corps of Engineers, 2004b). These moderateflow conditions at the Missouri River sites provide another flow scenario compared to the previous surveys at each site during the 2011 Missouri River flood (Huizinga, 2012), and during low-flow conditions in 2014 (Huizinga, 2015).

Structure A5054 on Interstate 72 at Hannibal, Mo., (site 31, fig. 1), was surveyed on July 18, 2018, also on the receding limb of a peak in the hydrograph observed at the streamgage at Hannibal, Mo. (station 05501600; U.S. Geological Survey, 2020; fig. 1). Streamflow on the Mississippi River was approximately $173,000 \mathrm{ft} 3 / \mathrm{s}$ as measured during the survey at structure A5054 at Hannibal, Mo. (table 3), which is less than the 50-percent annual exceedance probability (2-year recurrence interval) flood flow of $209,000 \mathrm{ft} 3 / \mathrm{s}$ at Hannibal (table C-M-2 in U.S. Army Corps of Engineers, 2004c).

Similarly, structure L0135 on Missouri State Highway 51 at Chester, Ill. (site 36, fig. 1), was surveyed on July 24, 2018, and streamflow on the Mississippi River was approximately 283,000 ft $3 / \mathrm{s}$ as obtained from the rating curve for the streamgage at Chester, Ill. (station 07020500; U.S. Geological Survey, 2020; fig. 1), and approximately 290,000 ft $3 / \mathrm{s}$ as measured during the survey (table 3). This streamflow has a daily exceedance of about 26 percent, and is less than the 50 -percent annual exceedance probability (2-year recurrence interval) flood flow of 480,000 ft $3 / \mathrm{s}$ at Chester (table D-28 in U.S. Army Corps of Engineers, 2004d). Structure A5076 on Missouri State Highway 34 at Cape Girardeau, Mo. (site 37, fig. 1), was surveyed on July 25, 2018, and streamflow on the Mississippi River was approximately 282,000 ft3/s as measured during the survey (table 3), which also is less than the 50 -percent annual exceedance probability (2-year recurrence interval) flood flow of 483,000 ft3/s at Cape Girardeau (station 07020850; table D-28 in U.S. Army Corps of Engineers, 2004d). Although daily flow statistics and exceedance probability data are not readily available for structure A1700 on Interstate 155 near Caruthersville, Mo. (site 38, fig. 1), it is assumed that the measured streamflow of $420,000 \mathrm{ft} 3 / \mathrm{s}$ follows the same trend as the upstream stations and is near or slightly less than the 50-percent annual exceedance probability at Caruthersville.

Flow conditions in these daily and annual exceedance ranges are in the low to moderate flood-flow regime. In an analysis of real-time scour monitoring data at Jefferson City, Mo., Huizinga (2014) noted that substantial pier scour begins soon after the onset of hydrograph rise (substantial rise of 8 feet [ft] or more), although the scour often does not reach maximum depth until the peak stage is reached or sometime thereafter (see fig. 35 in Huizinga, 2014). Although the flow conditions during these surveys may not have been at the peak streamflow for the spring season, the peak had occurred earlier in June (fig. 2), and flow was substantially higher than base flow based on the daily exceedance values. Although the scour scenario captured at the sites in this study likely does not represent the maximum scour potential, the cumulative information gathered at the sites during the course of multiple surveys in 2011, 2015, and 2018 remains useful for determining scour for a variety of flow conditions.

\section{Description of Equipment and Basic Processing}

The bathymetry of the Missouri or Mississippi River at each of the bridges was determined using a high-resolution MBMS. The various components of the MBMS used for this study are as described in reports about studies on the Missouri and Mississippi Rivers in Missouri (Huizinga, 2010, 2011, 2012, 2013, 2014, 2015, 2016, 2017a; 2020a; Huizinga and others, 2010) and on the Missouri and Yellowstone Rivers in North Dakota (Densmore and others, 2013). The survey methods used to obtain the data were similar to these previous studies, as were the measures used to ensure data quality. A brief description of the equipment follows; a more-complete description of the various system components and methods used in this study is available in the previous reports by Huizinga (2010), Huizinga and others (2010), and Densmore and others (2013).

An MBMS is an integration of several individual components: the multibeam echosounder (MBES), an inertial navigation system (INS), and a data-collection and data-processing computer. The MBES that was used for the 2018 surveys is the Norbit iWBMSh (fig. 3), operated at a frequency of 400 kilohertz (kHz). The iWBMSh is similar in operation to the MBES systems used in other previous studies in Missouri, except that it has a curved receiver array, which enables bathymetric data to be collected throughout a sound navigation and ranging (sonar) swath range of 210 degrees. Optimum data usually are collected in a swath of less than 160 degrees (80 degrees on each side of nadir, or straight down below the MBES); nevertheless, the swath can be electronically rotated to either side of nadir, enabling data along sloping banks to be captured up to a depth just below the water surface. The Norbit iWBMSh transducer head has an integrated INS (fig. 3A), the Applanix Position Orientation Solution for Marine Vessels (POS MV) OceanMaster system, that provides position in threedimensional space and measures the heave, pitch, roll, and heading of the vessel (and, thereby, the MBES) to accurately position the data received by the MBES. Real-time kinematic (RTK) differential corrections for the INS came from cellular communication with the MoDOT Global Navigation Satellite System (GNSS) real-time network for the navigation and tide solution during the 2018 surveys.

As in previous surveys (Huizinga, 2010, 2011, 2012, 2013, 2014, 2015, 2016, 2017a, b, 2020a, b, c, d), the navigation information from the 2018 surveys was postprocessed using the POSPac Mobile Mapping Suite (MMS) software (Applanix Corporation, 2017) to mitigate the effects of degraded positional accuracy of the vessel while near or under a bridge. POSPac MMS provides tools to identify and compensate for sensor and environmental errors and computes 

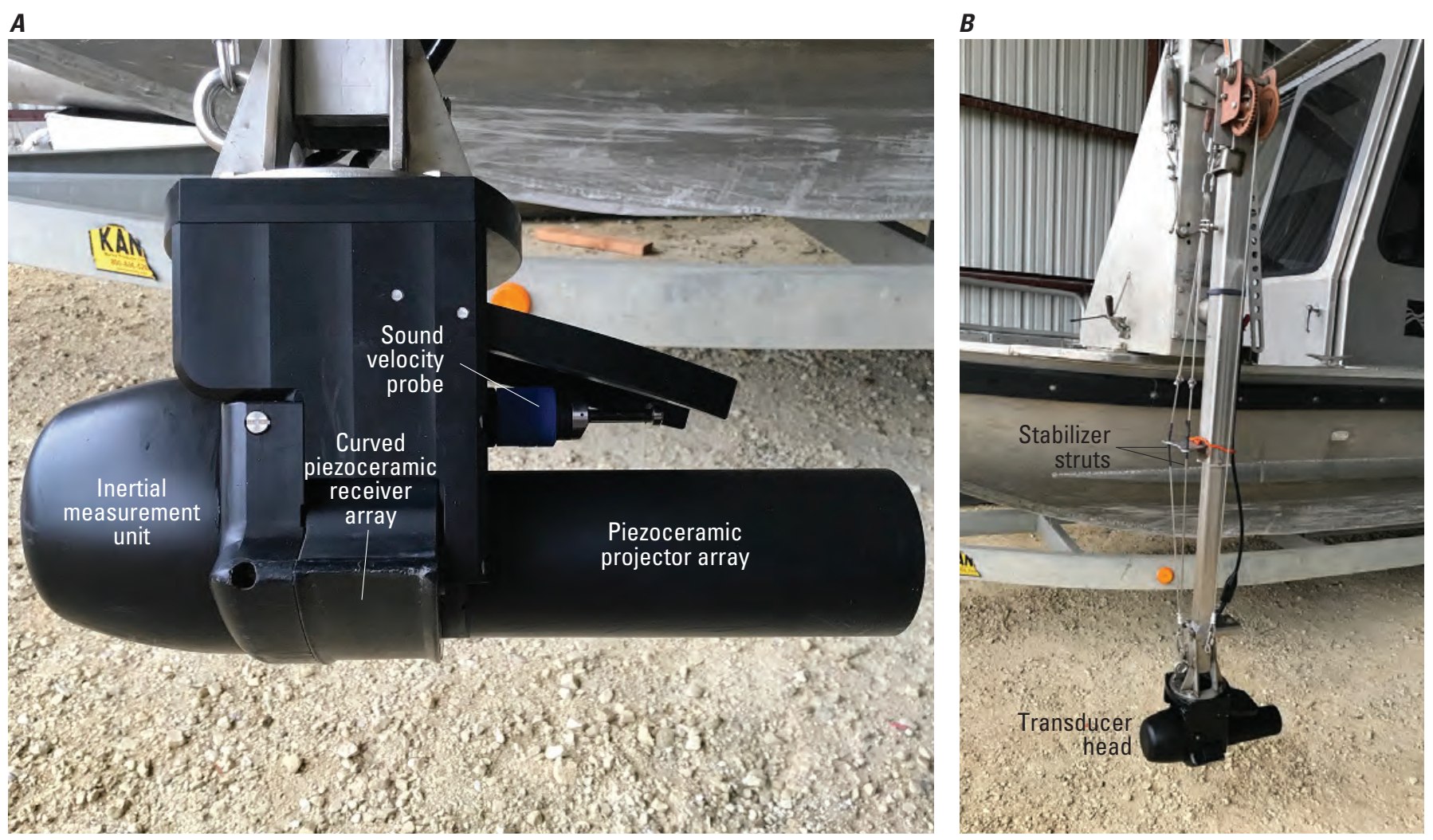

Figure 3. The Norbit iWBMSh multibeam echosounder. $A$, Viewed from the side, and $B$, Mounted on the port side of the U.S. Geological Survey boat.

an optimally blended navigation solution from the GNSS and inertial measurement unit (IMU) raw data. The blended navigation solution (called a "smoothed best estimate of trajectory" or "SBET" file) generated by postprocessing the navigation data was applied to the survey at a given bridge to minimize the effects of the GNSS outages while surveying under the bridges.

The data from the MBES and INS components were processed and integrated into a cohesive dataset for cleanup and visualization. A computer onboard the survey vessel ran the HYPACK/HYSWEEP data acquisition software (HYPACK, Inc., 2018) that was used to prepare for the bathymetric surveys and collect the survey data. After completing the surveys, the acquired depth data were further processed to remove data spikes and other spurious points in the multibeam swath trace, georeferenced using the navigation and position solution data from the SBET file from POSPac MMS, and visualized in HYPACK/HYSWEEP as a triangulated irregular network (also known as a "TIN" surface) surface or a point cloud. The georeferenced data were output to a comma-delimited file, either having no data reduction or filtered and reduced to a $1.64-\mathrm{ft}$ data resolution. These comma-delimited data were compiled into a geographic information system database for each site using the ArcGIS package (Esri, 2020), and are included with metadata in a USGS data release (Huizinga, 2020d).
Information about the velocity of the river at various points throughout each study reach were collected using an ADCP, similar to recent previous studies by Huizinga (2012, 2013, 2014, 2015, 2016, 2017a, b, 2020a, b, c, d). A Teledyne RD Instruments Rio Grande ADCP operating at $600 \mathrm{kHz}$ was used to obtain velocities at 1.64-ft increments, or "bins," throughout the water column. The Rio Grande 600-kHz ADCP operates in depths from 2.3 to $230 \mathrm{ft}$ and determines the velocity of the water by measuring the Doppler shift of an acoustic signal reflected from various particles suspended in the water (Mueller and others, 2013). By measuring the Doppler shift in four different beam directions, the velocity of the water in each bin can be determined in three dimensions.

\section{Basic Description of Methods}

The methods used to acquire and ensure the collection of quality data were the same as those used in previous studies using the MBES (methods are detailed in Huizinga and others, 2010; Huizinga, 2010, 2012). A brief summary of - and differences from - these methods are highlighted below. 


\section{Surveying Methods}

Generally, the surveyed area extended across the active channel from bank to bank, as in the previous studies on the Missouri and Mississippi Rivers on the periphery of Missouri (Huizinga, 2012, 2015). The surveyed reaches were about $1,640 \mathrm{ft}$ long in the direction of flow, positioned so that the surveyed highway bridges were about one-third to one-half of the total length from the upstream boundary, generally using about the same upstream and downstream boundaries as used in the 2011 flood study on the Missouri River (Huizinga, 2012), and the previous Mississippi River surveys (Huizinga, 2015). The upstream and downstream boundaries of the surveyed areas were assumed to be beyond the substantial hydraulic effects (wake vortices and shear flow) of the bridge structures.

As in previous studies, bathymetric data were obtained along longitudinal transect lines, and each survey was designed so that there was overlap of the survey swaths to attempt to ensure complete coverage of the channel bed and minimize sonic "shadows" (Huizinga and others, 2010). Substantial overlap was achieved for many of the surveyed swaths, except in shallow areas near the channel banks or spur dikes, and near in-flow structures, debris rafts, or moored barges. Areas near the bridge piers and along the banks also were surveyed in an upstream direction with the MBES swath electronically tilted to port or starboard to increase the acquisition of bathymetric data in the shallow areas, and higher on the banks and the sides of the piers. The electronically tilted swath generally was 120 degrees, extending from 10 degrees above horizontal on the bank-ward or pier-ward side of the survey vessel to 20 degrees past nadir below the vessel. To limit potential damage to the MBES head, most of the shallow areas (less than about $6 \mathrm{ft}$ of water depth) were not surveyed.

After completing the bathymetric survey with the MBMS at a given site, the velocity data were obtained with the ADCP on seven lateral sections across the channel within the study area. The position and speed of the boat was determined using a differential GNSS receiver mounted on a pole directly above the ADCP. The bottom-track reference method for determining boat speed was anticipated to be unusable because of moving channel-bed material, so the boat velocity was determined using the GNSS essential fix data (the NMEA-0183 GGA string [shorthand for the \$GPGGA standard output format for GNSS essential fix data defined by the National Marine Electronics Association 0183 standard that includes information on the three-dimensional location and accuracy of the GNSS receiver; National Marine Electronics Association, 2002]) from the differential GNSS receiver. The distance between the velocity section lines generally was about $260 \mathrm{ft}$. Three sections were upstream and four sections were downstream from the bridge being surveyed. Each section line was traversed in each direction across the river. The reported velocity values are the average from the two traverses of a given section line, using averaging algorithms from the Velocity
Mapping Toolbox (Parsons and others, 2013). Streamflow for a site was computed as the average of the streamflows from reciprocal pairs (two transects per section line) at the various sections in the reach. Generally, measured streamflow for an individual transect was within 5 percent of the average.

\section{Survey Quality-Assurance/Quality-Control Measures}

A quality-assurance plan has been established for streamflow measurements using ADCPs that includes several instrument diagnostic checks and calibrations. These standard operating procedures were followed when acquiring the velocity profile data for these surveys, including a moving-bed test and paired ADCP measurements at each transect to mitigate directional bias. For a detailed discussion of these procedures, see Mueller and others (2013).

For the MBMS, the principal quality-assurance measures were assessed in real time during the survey. The MBMS operator continuously assessed the quality of the collected data during the survey by making visual observations of acrosstrack swaths (such as convex, concave, or skewed bed returns in flat, smooth bottoms), noting data-quality flags and alarms from the MBES and the INS, and noting comparisons between adjacent overlapping swaths. In addition to the real-time quality-assurance assessments during the survey, beam angle checks and a suite of patch tests were executed to ensure quality data were acquired from the MBMS for the 2018 surveys. The beam angle test was completed at Sugar Creek Lake (not shown on figure) near Moberly, Mo. (fig. 1). Patch tests were completed on the Osage River near Westphalia, Mo. (fig. 1) on June 28 before the 2018 surveys, and on the Mississippi River two times during the 2018 surveys after striking an object during the surveys, to document any potential changes to the mounting angles from the strikes.

\section{Beam Angle Check}

A beam angle check is used to determine the accuracy of the depth readings obtained by the outer beams (greater than 25 degrees from nadir [vertical]) of the MBES (U.S. Army Corps of Engineers, 2013), which may change with time as a result of inaccurate sound velocities, physical configuration changes, and overall depth being surveyed. The HYPACK/ HYSWEEP software has a utility that develops a statistical assessment of the quality of the outer beams compared to a reference surface (HYPACK, Inc., 2018). On September 6, 2018, a reference surface was surveyed for a part of Sugar Creek Lake near Moberly, Mo. (fig. 1), and check lines were run across the reference surface. Included with the measurement was a sound-velocity profile cast to document and quantify any stratification in the water column near the reference surface. The results of this beam angle check (table 4) were within the recommended performance standards used by the U.S. Army Corps of Engineers for hydrographic surveys 
Table 4. Results of a beam angle check from two check lines over a reference surface at Sugar Creek Lake near Moberly, Missouri, on September 6, 2018.

$[<$, less than; --, no data]

\begin{tabular}{ccccc}
\hline $\begin{array}{c}\text { Beam angle limit } \\
\text { (degrees) }\end{array}$ & $\begin{array}{c}\text { Maximum outlier } \\
\text { (feet) }\end{array}$ & $\begin{array}{c}\text { Average difference } \\
\text { (feet) }\end{array}$ & $\begin{array}{c}\text { Standard deviation } \\
\text { (feet) }\end{array}$ & $\begin{array}{c}\text { 95-percent confidence } \\
\text { (feet) }\end{array}$ \\
\hline 0 & 0.56 & 0.00 & 0.10 & 0.20 \\
5 & 0.43 & 0.00 & 0.10 & 0.16 \\
10 & 0.46 & 0.03 & 0.10 & 0.16 \\
15 & 0.43 & 0.03 & 0.07 & 0.16 \\
20 & 0.43 & 0.03 & 0.10 & 0.20 \\
25 & 0.43 & 0.03 & 0.10 & 0.20 \\
30 & 0.49 & 0.00 & 0.10 & 0.20 \\
35 & 0.49 & 0.03 & 0.13 & 0.23 \\
40 & 0.62 & 0.07 & 0.13 & 0.23 \\
45 & 0.10 & 0.10 & 0.23 \\
50 & 0.66 & 0.10 & 0.10 & 0.20 \\
55 & 0.72 & 0.13 & 0.10 & 0.16 \\
65 & 0.92 & 0.16 & 0.10 & 0.16 \\
& 0.89 & 0.16 & 0.07 & 0.16 \\
\hline- & 0.69 & Performance standardsa & & $<0.80$ \\
\hline- & & $<0.20$ & -- & Met \\
\hline
\end{tabular}

aPerformance standard check values are from U.S. Army Corps of Engineers (2013, table 3-1) for soft sand/silt bottoms.

for all the representative angles below 65 degrees (U.S. Army Corps of Engineers, 2013), permitting the use of the central 130 degrees of the sonar swath with confidence.

Ideally, the average depth of the reference surface used in the beam angle check would be equal to or greater than the depth in the area being surveyed. The depth of the Missouri and Mississippi Rivers in each study reach generally was impossible to estimate before each survey because of the dynamic nature of the channel-bed and flow conditions. The average depth of the reference surface on Sugar Creek Lake was about $27 \mathrm{ft}$, whereas the average depths of the Missouri and Mississippi Rivers observed during the 2018 surveys ranged from 23 to $46 \mathrm{ft}$ (the average depth is the difference between the average water surface elevation and average channel-bed elevation in table 3). However, as described earlier in the "Surveying Methods" section in this report, areas with depths substantially greater than $27 \mathrm{ft}$ generally had substantial overlap of the surveyed swath with adjacent swaths.

Data from the outer beams in these areas were able to be either verified or removed to mitigate any detrimental effects.

\section{Patch Tests}

Patch tests are a series of dynamic calibration tests that are used to check for subtle variations in the orientation and timing of the MBES with respect to the INS and real-world coordinates. The patch tests are used to determine timing offsets caused by latency between the MBES and the INS, and angular offsets to roll, pitch, and yaw caused by the alignment of the transducer head (fig. 4). These offsets have been observed to be essentially constant for a given survey, barring an event that causes the mount to change such as striking a floating or submerged object (Huizinga, 2010, 2011, 2012, 2014, 2015, 2016, 2017a, 2020a). The offsets determined in the patch test are applied when processing the data collected during a survey.

Patch tests were completed before the 2018 surveys at the Osage River near Westphalia, Mo. (fig. 1), and twice during the surveys after striking an object at that site (table 5). Although the MBES had several other minor strikes of floating debris at various times during the 2018 surveys, there were no apparent changes to the roll, pitch, or yaw angles from the beginning to the end of the surveys.

For this study, there was no measured timing offset (table $5 ; \Delta t=0$, fig. 4), which is consistent with latency test results for this boat and similar equipment configurations used in other surveys (Huizinga, 2010, 2011, 2012, 2013, 2014, 2015, 2016, 2017a, 2020a; Huizinga and others, 2010). The measured angular offset for pitch and yaw was 0.00 degree, and the measured angular offset for roll was -0.30 degree for all patch tests (table 5). It was noted in the earliest work with the MBMS in Missouri (Huizinga, 2010) that a sensitivity 


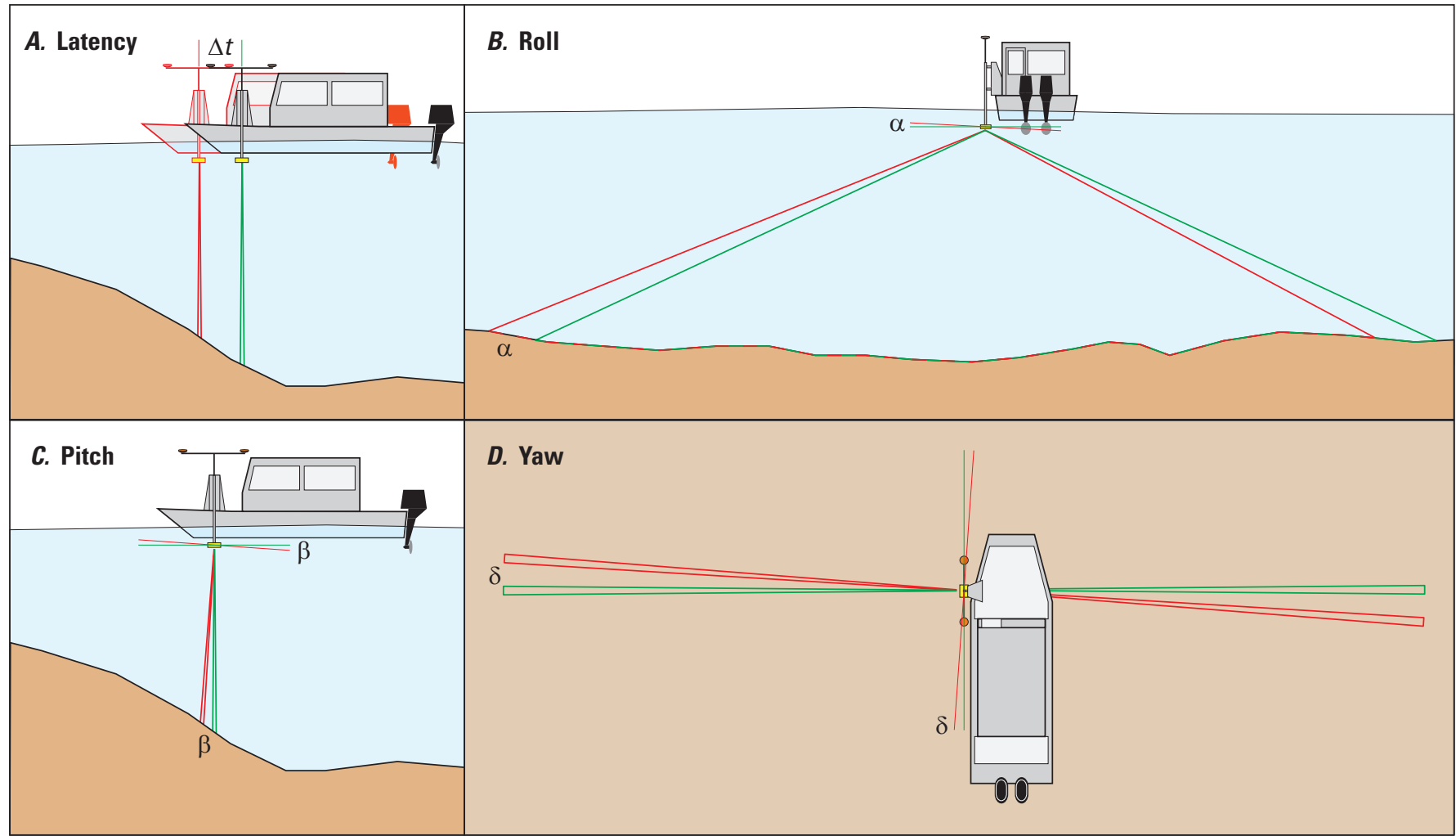

\section{EXPLANATION}

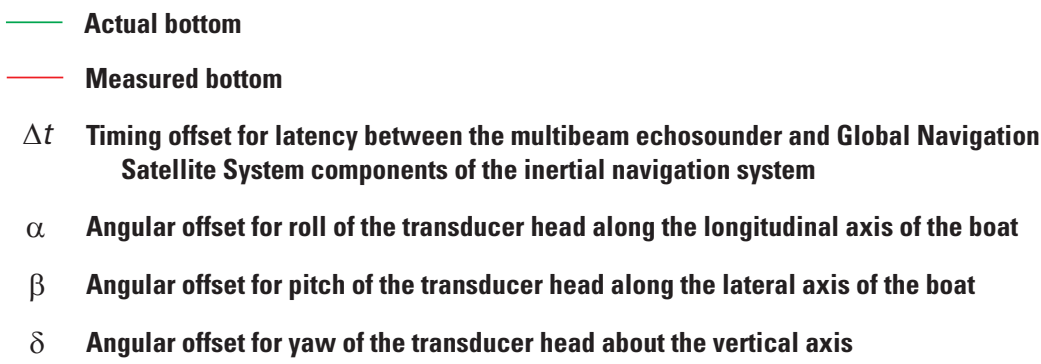

Figure 4. Generalized effects on data from a multibeam echosounder. $A$, Timing offset for latency. $B$, Angular offset for roll. $C$, Angular offset for pitch. $D$, Angular offset for yaw.

Table 5. Patch test results at various locations from June 28 to July 24, 2018.

[Mo., Missouri; Ill., Illinois]

\begin{tabular}{cccccc}
\hline Date of test & $\begin{array}{c}\text { Timing offset } \\
\text { (second) }\end{array}$ & $\begin{array}{c}\text { Angular offset } \\
\text { for roll } \\
\text { (degree) }\end{array}$ & $\begin{array}{c}\text { Angular offset } \\
\text { for pitch } \\
\text { (degree) }\end{array}$ & $\begin{array}{c}\text { Angular offset } \\
\text { for yaw } \\
\text { (degree) }\end{array}$ & Location \\
\hline $06 / 28 / 18$ & 0 & -0.30 & 0.00 & 0.00 & Osage River near Westphalia, Mo. \\
$07 / 18 / 18$ & 0 & -0.30 & 0.00 & 0.00 & Mississippi River at Hannibal, Mo. \\
$07 / 24 / 18$ & 0 & -0.30 & 0.00 & 0.00 & Mississippi River at Chester, Ill. \\
\hline
\end{tabular}


analysis of the four offsets implied that the ultimate position of surveyed points in three-dimensional space was least sensitive to the angular offset for yaw, whereas it was most sensitive to the angular offset for roll.

The bathymetric data were processed to apply the offsets determined from the patch tests and to remove data spikes and other spurious points in the multibeam swaths through the use of automatic filters and manual editing. The bathymetric data were then projected to a three-dimensional grid at a resolution of $1.64 \mathrm{ft}$ using the Combined Uncertainty and Bathymetry Estimator (CUBE) method (Calder and Mayer, 2003), as implemented in the MBMax processing package of the HYPACK/HYSWEEP software (HYPACK, Inc., 2018) and used to generate a gridded raster surface of the channel bed near each bridge (hereinafter referred to as a "bathymetric surface") using ArcGIS. The bathymetric surface for each site from the 2018 survey was compared to similar bathymetric surfaces created from previous surveys at a bridge by taking the difference between the 2018 bathymetric surface and the previous bathymetric surface. Statistics of the elevations for each bathymetric surface were determined, as were statistics of the differences between the surfaces. Sediment volumes for cut (scour) and fill (deposition) between the 2018 survey and any previous surveys also were determined from differences in the bathymetric surfaces using ArcGIS.

\section{Uncertainty Estimation}

Similar to the previous studies of bathymetry in Missouri (Huizinga, 2010, 2011, 2012, 2013, 2014, 2015, 2016, 2017a, b, 2020a, b, c, d), uncertainty in the surveys was estimated by computing the total propagated uncertainty (TPU) for each survey-grid cell in the bathymetric surface of each survey area, using the CUBE method (Calder and Mayer, 2003) as implemented in the MBMax processing package of the HYPACK/ HYSWEEP software (HYPACK, Inc., 2018). The CUBE method allows all random system component uncertainties and resolution effects to be combined and propagated through the data processing steps, which provides a robust estimate of the spatial distribution of possible uncertainty within the survey area (Czuba and others, 2011). Thus, the TPU of a point is a measure of the accuracy to be expected for such a point when all relevant error sources are taken into account. Statistics of TPU for each of the survey areas are shown in table 6, and an example of the spatial distribution of TPU typically observed in the survey data is shown in figure 5 for the bathymetric data at structure A1700 on Interstate 155 over the Mississippi River.

The largest TPU in this group of surveys was about $3.74 \mathrm{ft}$ (table 6); however, as noted in previous studies, TPU values of this magnitude typically happened near high-relief features, such as the front or side of a pier footing (fig. 5). More than 98 percent of the TPU values were less than $0.50 \mathrm{ft}$ (table 6), which is within the specifications for a "Special Order" survey, the most-stringent survey standard of the International Hydrographic Organization (IHO; International Hydrographic Organization, 2008). As has been noted in previous surveys with this equipment, the TPU values were larger near moderate-relief features (banks, spur dikes, rock riprap and outcrops, and scour holes near piers). Occasionally, the TPU values also were larger (1.00 ft or greater) in the outermost beam extents of the multibeam swath in the overlap with an adjacent swath, particularly when the MBES head was electronically tilted for the survey lines along the banks or near the piers. Overlapping adjacent swaths in the channel thalweg (the line of maximum depth in the channel) also can display larger TPU values because substantial bed movement can happen between survey passes. More than 77 percent of the TPU values were less than $0.25 \mathrm{ft}$ (table 6 ). The tops of bridge substructural elements (pier footings and seal courses) typically had TPU values of less than $0.25 \mathrm{ft}$.

The survey at structure A1700 on Interstate 155 had the highest average value of TPU, as well as the lowest percentage of bathymetry points with an uncertainty of less than $0.25 \mathrm{ft}$ (table 6). There were a few impediments to surveying at this site in the form of barge traffic during the survey, but otherwise the survey was obtained with relatively smooth

Table 6. Total propagated uncertainty results for bathymetric data at a 1.64-foot grid spacing from surveys on the Missouri and Mississippi Rivers on the periphery of Missouri, from July 16 to August 13, 2018.

[MoDOT, Missouri Department of Transportation; ft, foot]

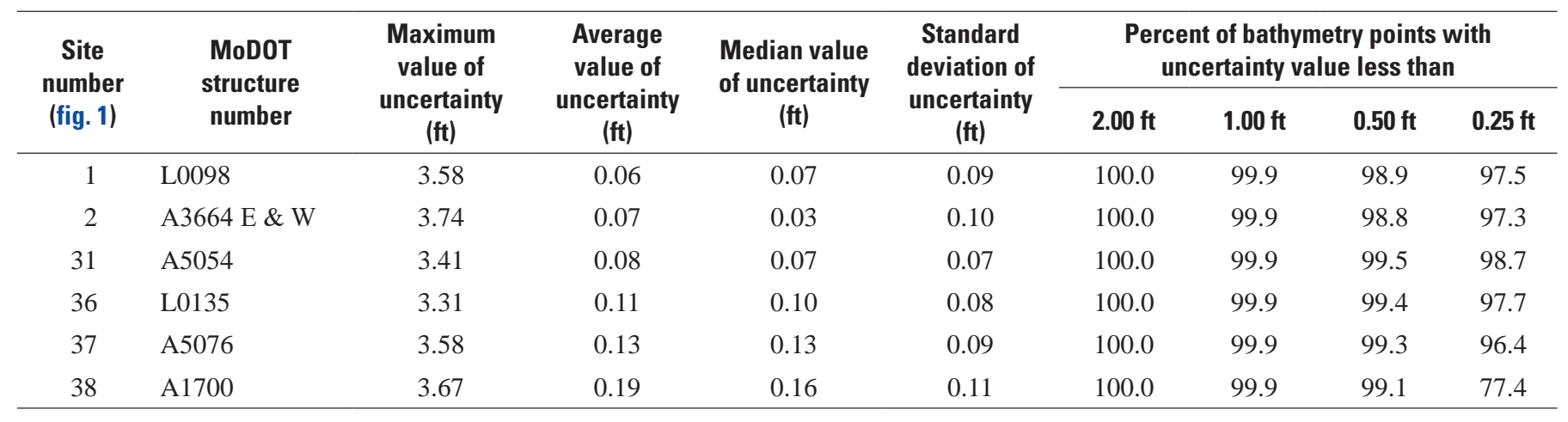




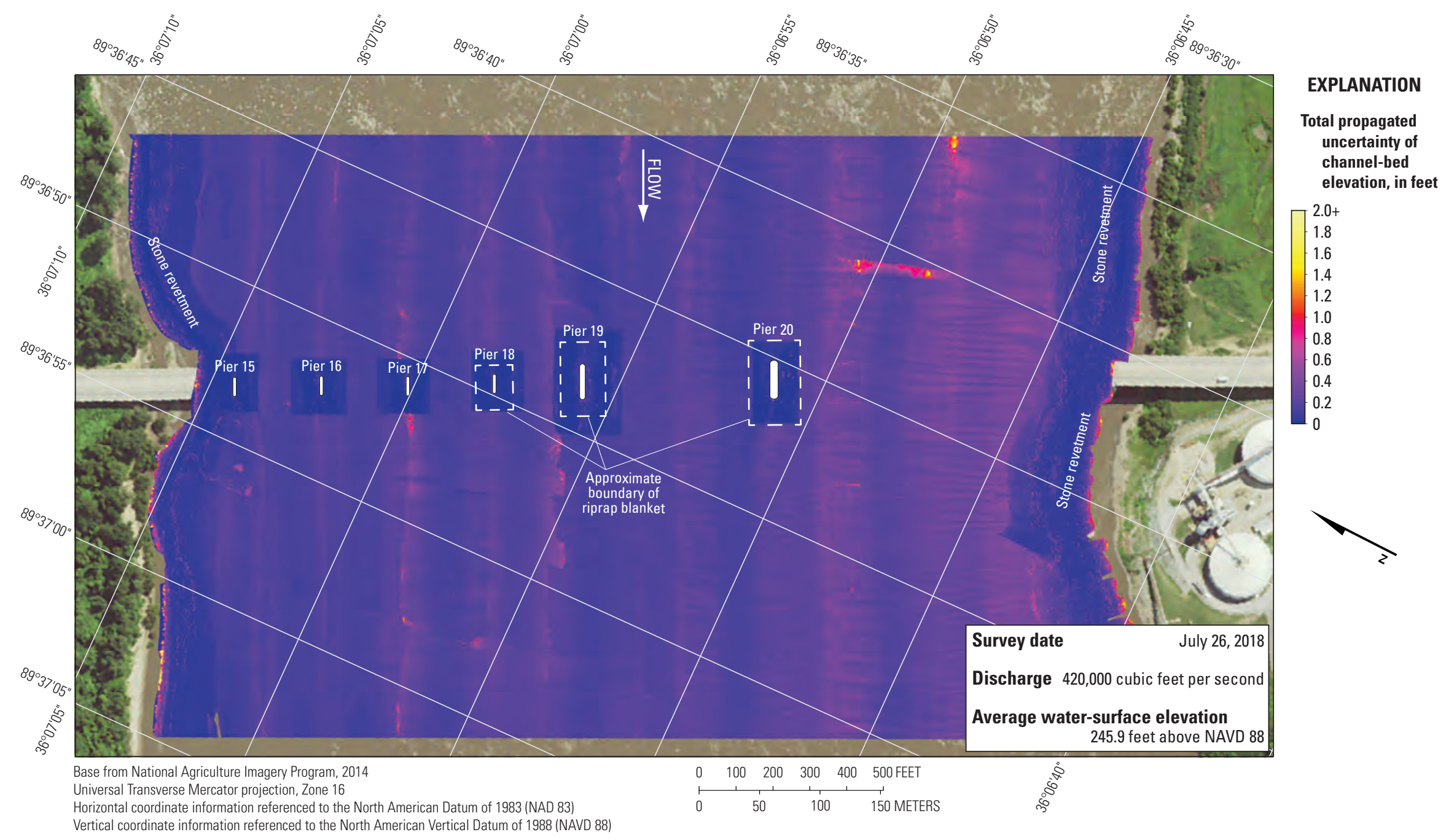

Figure 5. Total propagated uncertainty of bathymetric data from the Mississippi River channel near structure A1700 on Interstate 155 near Caruthersville, Missouri. 
longitudinal swathes (fig. 5), which was the case at nearly all the sites surveyed in this study. The primary anomaly at this site was in the upstream mid-channel area where abrupt course changes or insufficient overlap of the swath outer beams resulted in higher TPU values. Secondary anomalies were observed along the banks, where the sonar was used in an electronically tilted configuration to extend the potential coverage in these areas, resulting in higher TPU values. Generally, the magnitude and distribution of TPU values observed at this site are representative of those observed at all the other surveyed sites.

\section{Results of Bathymetric and Velocimetric Surveys}

The site-specific results for each bridge are discussed in the following sections grouped by river, starting with the upstream-most bridge site and progressing downstream. The site-specific results are followed by a discussion of general findings that are not specific to a particular site. The range of bed elevations described as "the channel-bed elevations" for each survey was based on statistical analysis of the gridded raster surface of the bathymetry data at each site, and covers the percentile range from 5 to 95 percent of the data. Because the surveys generally were limited to the active channel from bank to bank excluding overbank areas, this percentile range generally covered the channel bed but excluded the banks and localized high or low spots, such as spur dikes or scour holes near piers. All elevation data were referenced to the North American Vertical Datum of 1988 (NAVD 88).

For consistency with earlier studies, dune sizes are described in general terms for each of the bridge sites using the categories set by Huizinga (2012) for the discussion of bathymetry during the 2011 flood. In this report, small dunes and ripples are those that are less than $5 \mathrm{ft}$ high from crest to trough, medium dunes are those that are 5 to $10 \mathrm{ft}$ high, large dunes are those that are 10 to $15 \mathrm{ft}$ high, and very large dunes are those that are $15 \mathrm{ft}$ or more in height.

Previous bathymetric surveys have happened at all the bridge sites in this study (Huizinga, 2012, 2015); furthermore, several of the sites had a Level 2 bridge scour assessment (Lagasse and others, 1991; Huizinga and Rydlund, 2004). A map showing the difference in channel-bed elevation for the area common to the comparison surveys is included for each site, and data from previous surveys are included in the crosssection plot for that bridge. The difference maps were created by taking the difference between the 2018 raster surface and a previous survey raster surface at a given bridge, and summary statistics (maximum, minimum, and average) of the difference rasters were determined. The surveys are broadly compared based on their timing and the streamflow at the time of the survey. If a site was subject to a Level 2 assessment, the cross section of the channel at the bridge (typically on the downstream side of the bridge) obtained during the
Level 2 assessment is included on the cross-section plot for that bridge. Additionally, shaded TIN images of the channel and side of pier were prepared for each surveyed pier. These visualizations are shown in appendix figures 1.1 to 1.8.

Although the configuration of the channel bed and the underlying sediment transport conditions at a site are associated with an instantaneous streamflow in the discussions that follow, a given bathymetric surface actually is a reflection of more than those instantaneous transport conditions. A wide variety of factors affect the channel-bed configuration of a reach for a specific streamflow (Gilbert and Murphy, 1914; Simons and Richardson, 1966), including flow velocities and velocity distribution, the size and timing of previous flood rises, whether or not the stage currently is rising or falling, and other local hydraulic conditions. Furthermore, the channel-bed configuration at a site is affected by upstream and local sediment conditions and contributions, as well as water temperature and other seasonal variations (Simons, Li and Associates, 1985). Because of the myriad number and interactions of factors affecting sediment transport conditions and the resultant bed configuration, it was assumed that the configuration and size of bed forms observed during the current (2018) surveys on the periphery of Missouri depend on more than the instantaneous streamflow at a given site. Although it is beyond the scope of the current (2018) study to examine all the antecedent conditions that created the observed channel-bed configuration, the comparisons with previous surveys under different flow conditions nevertheless contribute to understanding the many complexities of sediment transport.

As in recent previous studies (Huizinga, 2012, 2013, 2014, 2015, 2016, 2017a, 2020a), when discussing the vertically averaged velocity values obtained during the surveys in the sections that follow, neighboring vectors having random variations in direction and magnitude were taken as an indication of nonuniform flow in the section resulting from shear and wake vortices. Conversely, neighboring vectors having gradual and systematic variations were taken as an indication of uniform flow in the section. The Missouri and Mississippi Rivers are highly turbulent even in the absence of structures that generate strong shear or wakes, but in the interest of conciseness, nonuniform flow is loosely described as "turbulent" in the following sections. The velocity data for each cross section are an average of two velocity transects, spatially averaged to the section line using algorithms in the Velocity Mapping Toolbox (Parsons and others, 2013).

\section{Sites on the Missouri River}

There are five unique highway crossings of the Missouri River upstream from Kansas City to the Missouri-Iowa State line (table 1; fig. 1). Two of the crossings are maintained by MoDOT, and were surveyed as part of this study. Bathymetry and velocity data from these two surveys are included with metadata in Huizinga (2020d). Bathymetry data from earlier surveys at all five crossings also are included with metadata in Huizinga (2020d). 


\section{Structure L0098 on U.S. Highway 136 at Brownville, Nebraska}

Structure L0098 (site 1) on U.S. Highway 136 crosses the Missouri River at river mile (RM) 535.3 at Brownville, Nebr., in the northwestern corner of Missouri (fig. 1). The site was surveyed on August 13, 2018, and the average water-surface elevation near the bridge, determined by the RTK GNSS tide solution, was $892.3 \mathrm{ft}$ (table 3). Streamflow on the Missouri River was about 77,800 ft3/s during the survey (table 3).

The survey area was about 1,640 ft long and about $740 \mathrm{ft}$ wide, extending across the active channel from bank to bank (fig. 6). The upstream end of the survey area was about $740 \mathrm{ft}$ upstream from the centerline of structure L0098. The channelbed elevations ranged from about 863 to $881 \mathrm{ft}$ for most of the surveyed area (5 to 95 percentile range of the bathymetric data; table 3; fig. 7), except near pier 3 and on the downstream sides of the various spur dikes on the left (east) bank (fig. 6). The channel bed was covered with medium and small dunes and ripples. As in previous surveys (Huizinga, 2012, 2015), a rock outcrop was present on the right (west) bank upstream from the bridge, and stone revetment was present on the right bank downstream from the bridge (fig. 6).

A local scour hole near pier 3 had a minimum channelbed elevation of about $845 \mathrm{ft}$ (table 7), about $20 \mathrm{ft}$ below the average channel bed immediately upstream from the pier (fig. 6) and the overall minimum channel-bed elevation for the surveyed reach (table 3). Information from bridge plans
(Missouri Department of Transportation, written commun., 2002) indicates that pier 3 is founded on sheet piling caissons on bedrock, with about $30 \mathrm{ft}$ of bed material between the bottom of the scour hole and bedrock at the upstream face of the pier (fig. 8; table 7). The unique configuration of the sheet pile caissons and ice breaker of the pier are clearly seen in the shaded TIN images for main channel pier 3 (fig. 1.1). The surveyed bed along the cross section generally was between the two previous multibeam surveys in 2011 and 2014, except in an area of deposition near the left bank (fig. 8).

The difference between the survey on August 13, 2018, and the previous nonflood survey on June 3,2014, indicates general deposition from 2014 to 2018, with moderate deposition of as much as $7 \mathrm{ft}$ in the main part of the channel and substantial deposition of more than $20 \mathrm{ft}$ (along with localized erosion of as much as $15 \mathrm{ft}$ ) near the spur dikes on the left (east) side of the channel (fig. 9). However, there were several areas of moderate scour of as much as $10 \mathrm{ft}$, particularly near the base of the right (west) bank downstream from the bridge, and in the area around and downstream from pier 3. Minor deposition of as much as $3 \mathrm{ft}$ is indicated along the rock outcrop and stone revetment on the right (west) bank, but may be the result of minor positional variations between the surveys. The average difference between the bathymetric surfaces (the statistical average value of the gridded raster surface [fig. 9] created from the difference between the 2018 and 2014 [previous] survey gridded raster bathymetric surfaces) was $+0.01 \mathrm{ft}$ (table 8), indicating a general balance between aggradation

\section{Structure L0098 on U.S. Highway 136}

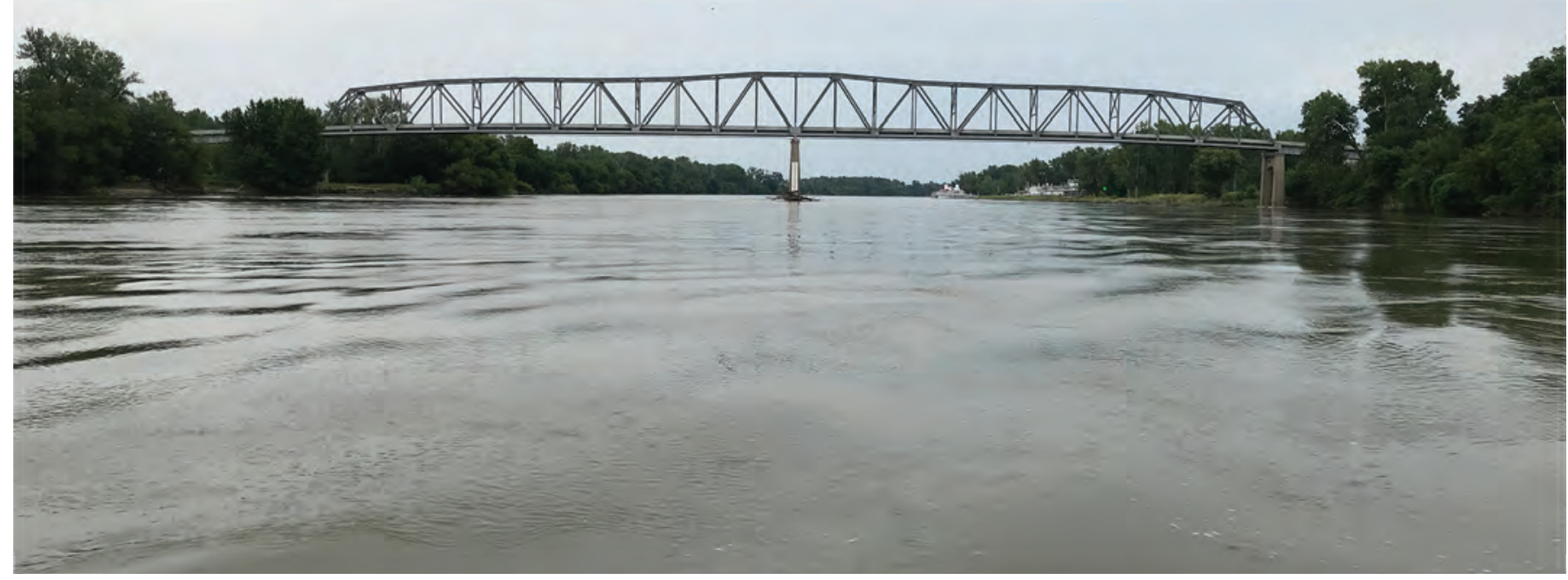




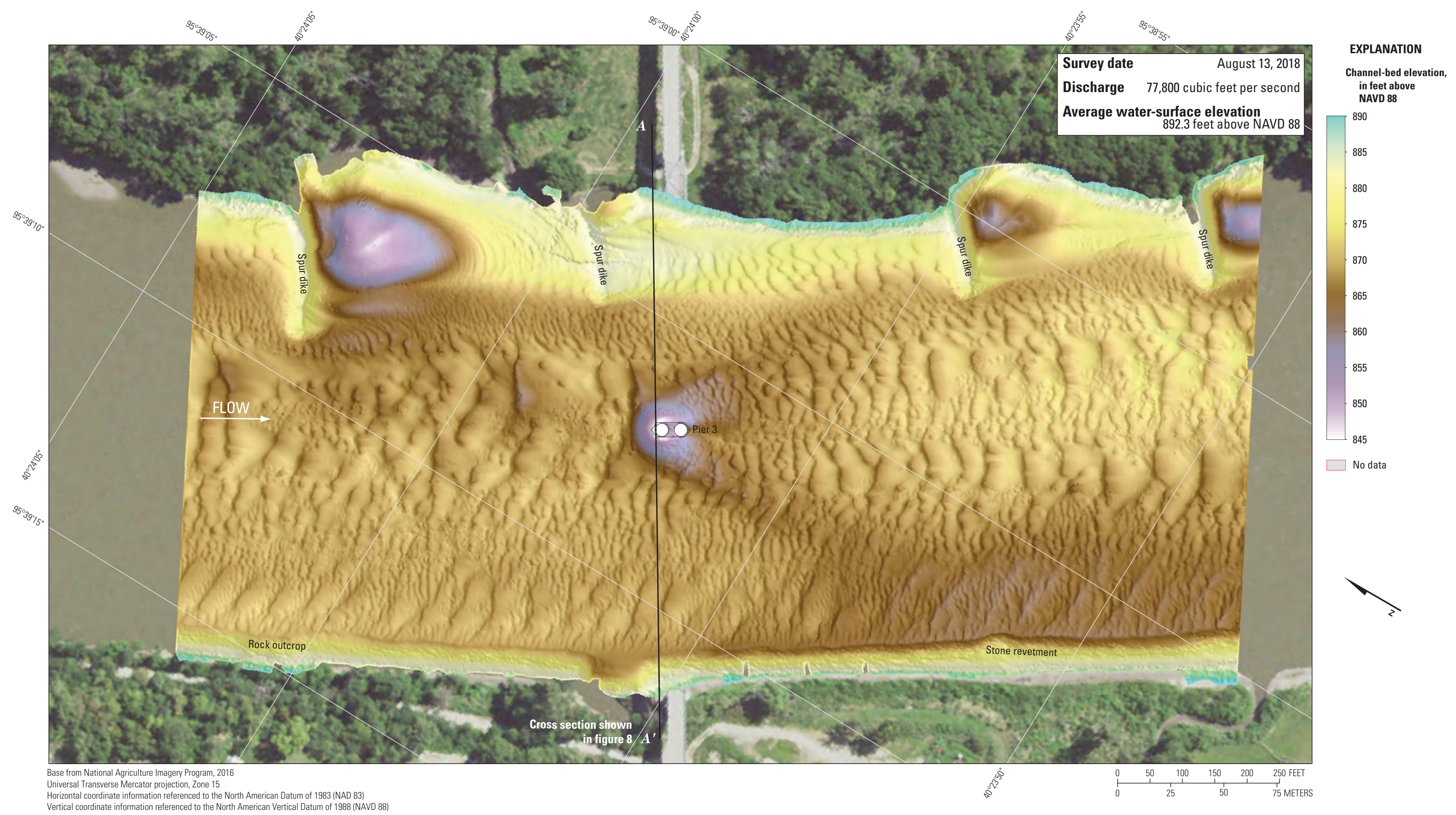

Figure 6. Bathymetric survey of the Missouri River channel near structure L0098 on U.S. Highway 136 at Brownville, Nebraska. 


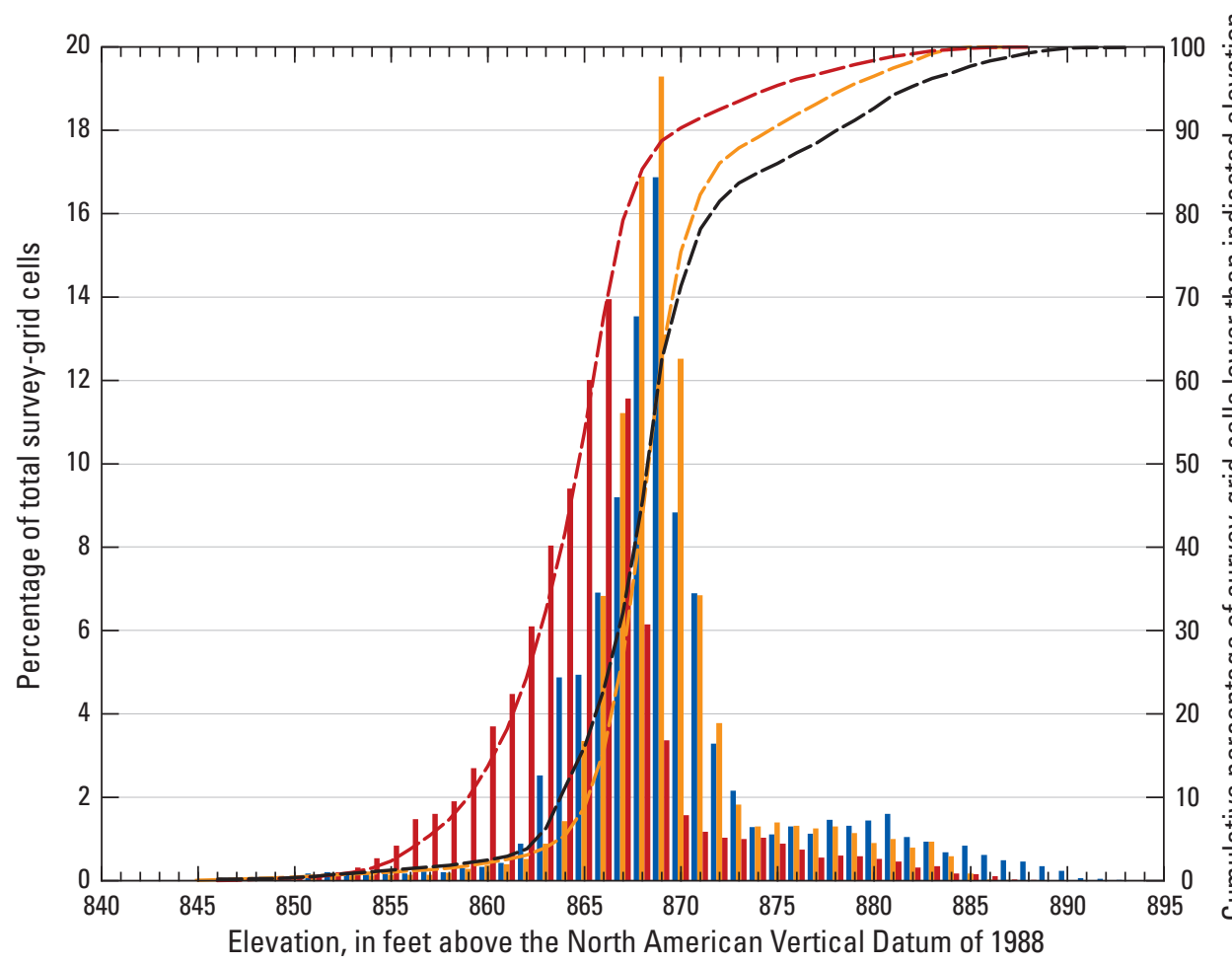

\section{EXPLANATION}

$\left[\mathrm{ft}^{3} / \mathrm{s}\right.$, cubic foot per second]

Frequency distribution

2018 survey data; $77,800 \mathrm{ft}^{3} / \mathrm{s}$

2014 survey data; $39,800 \mathrm{ft}^{3} / \mathrm{s}$

2011 survey data; $225,000 \mathrm{ft}^{3} / \mathrm{s}$

Cumulative percentage

- 2018 survey data; $77,800 \mathrm{ft}^{3} / \mathrm{s}$

_ 2014 survey data; $39,800 \mathrm{ft}^{3} / \mathrm{s}$

- 2011 survey data; $225,000 \mathrm{ft}^{3} / \mathrm{s}$

Figure 7. Frequency distribution of bed elevations for bathymetric survey-grid cells in 1-foot elevation bins on the Missouri River near structure L0098 on U.S. Highway 136 at Brownville, Nebraska, on August 13, 2018, compared to previous surveys (Huizinga, 2012, 2015).

and degradation between the 2014 and 2018 surveys for the area common to both surveys. The net volume of cut in the reach from 2014 to 2018 was about 43,200 cubic yards (yd3), and the net volume of fill was about $43,500 \mathrm{yd}^{3}$, resulting in a net gain of about $300 \mathrm{yd}^{3}$ of sediment. This similarity between 2014 and 2018 is further substantiated by the frequency distribution of bed elevations (fig. 7), which clearly shows the 2018 distribution as being similar in shape to 2014, with nearly equal values at the 50 percent point of the cumulative percentage curves.

The difference between the survey on August 13, 2018, and the previous flood survey on July 13, 2011, indicates substantial deposition has occurred throughout the channel reach from 2011 to 2018 (fig. 10). Widespread moderate deposition of as much as $15 \mathrm{ft}$ was observed upstream and downstream from the bridge, and more than $20 \mathrm{ft}$ of deposition was observed downstream from the spur dikes on the left (east) bank (fig. 10). Small, localized areas of minor scour were observed immediately downstream from the spur dikes, near pier 3, and at the base of the right (west) bank at the extreme downstream end of the reach (fig. 10). Minor deposition of $3 \mathrm{ft}$ or less indicated along the rock outcrop and stone revetment on the right (west) bank substantiates the probability of minor positional variations between the surveys, because the difference between 2011 and 2018 is less than that between 2014 and 2018. The average difference between the bathymetric surfaces was $+3.77 \mathrm{ft}$ (table 8), indicating substantial overall channel aggradation between the 2011 and 2018 surveys. The net volume of cut in the reach from 2011 to 2018 was about $7,380 \mathrm{yd}^{3}$, and the net volume of fill was about $169,000 \mathrm{yd}^{3}$, resulting in a net gain of about $161,600 \mathrm{yd}^{3}$ of sediment. This difference is substantiated by the frequency distribution of bed elevations (fig. 7), which shows the 2018 as being similar in shape to 2011, but shifted about $4 \mathrm{ft}$ higher in elevation than 2011.

The vertically averaged velocity vectors indicate mostly uniform flow throughout the reach (fig. 11). A maximum velocity of about 8 feet per second (ft/s) was present in the upstream middle of the channel and a minimum of $1 \mathrm{ft} / \mathrm{s}$ with flow reversal was present downstream from the various spur dikes in the reach (fig. 11). The wake vortices downstream from pier 3 were not pronounced, and seemed to be no greater than the general non-uniformity of flow observed in the channel (fig. 11). Minor turbulence was present in all the sections (fig. 11). 
Table 7. Results near piers from surveys on the Missouri and Mississippi Rivers on the periphery of Missouri, from July 16 to August 13, 2018.

[MoDOT, Missouri Department of Transportation; ft, foot; --, not known/applicable; all elevations are in feet above the North American Vertical Datum of 1988]

\begin{tabular}{|c|c|c|c|c|c|c|c|c|c|c|c|}
\hline \multirow[b]{2}{*}{$\begin{array}{c}\text { Site } \\
\text { number } \\
\text { (fig. 1) }\end{array}$} & \multirow[b]{2}{*}{$\begin{array}{c}\text { MoDOT } \\
\text { structure } \\
\text { number }\end{array}$} & \multirow[b]{2}{*}{$\begin{array}{c}\text { MoDOT } \\
\text { pier } \\
\text { number }\end{array}$} & \multicolumn{4}{|c|}{ Foundation information } & \multirow[b]{2}{*}{$\begin{array}{l}\text { Approximate } \\
\text { minimum } \\
\text { elevation in } \\
\text { scour hole } \\
\text { near piera } \\
\text { (ft) }\end{array}$} & \multirow[b]{2}{*}{$\begin{array}{l}\text { Approximate } \\
\text { elevation of } \\
\text { scour hole at } \\
\text { upstream } \\
\text { pier face } \\
\text { (ft) }\end{array}$} & \multirow[b]{2}{*}{$\begin{array}{l}\text { Approximate } \\
\text { elevation of } \\
\text { bedrock } \\
\text { near pier } \\
\text { (ft) }\end{array}$} & \multirow[b]{2}{*}{$\begin{array}{l}\text { Approximate } \\
\text { distance } \\
\text { between bottom } \\
\text { of scour hole } \\
\text { and bedrock } \\
\text { (ft) }\end{array}$} & \multirow[b]{2}{*}{$\begin{array}{c}\text { Depth } \\
\text { of scour } \\
\text { hole from } \\
\text { upstream } \\
\text { channel bed } \\
\text { (ft) }\end{array}$} \\
\hline & & & Type & $\begin{array}{c}\text { Width } \\
\text { (ft) }\end{array}$ & $\begin{array}{c}\text { Penetration } \\
\text { into bedrock } \\
\text { (ft) }\end{array}$ & $\begin{array}{l}\text { Seal course } \\
\text { or pile cap } \\
\text { bottom } \\
\text { elevation } \\
\text { (ft) }\end{array}$ & & & & & \\
\hline 1 & L0098 & 3 & Caisson & 21 & 0 & -- & 845 & 845 & 815 & 30 & 20 \\
\hline \multirow{3}{*}{2} & \multirow{3}{*}{$\begin{array}{l}\text { A3664 } \\
\text { E \& W }\end{array}$} & 10 & Drilled shaft & 30 & 25 & 758.00 & 777 & 777 & 745 & 32 & 6 \\
\hline & & 9 & Drilled shaft & 24 & 25 & 774.00 & b758 & 769 & 745 & b13 & b32 \\
\hline & & 8 & Pile cap & 19.5 & 1 & 789.00 & b758 & 797 & 745 & b13 & b32 \\
\hline \multirow{7}{*}{31} & \multirow{7}{*}{ A5054 } & 11 & Pile cap & 36 & 0 & 419.00 & 440 & 443 & 351 & 89 & 3 \\
\hline & & 10 & Pile cap & 36 & 0 & 421.00 & 443 & c445 & 357 & 86 & c1 \\
\hline & & 9 & Pile cap & 35 & 0 & 411.00 & 436 & c439 & 380 & 56 & c3 \\
\hline & & 8 & Drilled shaft & 36 & 15 & 405.00 & 428 & 429 & 394 & 34 & 19 \\
\hline & & 7 & Drilled shaft & 36 & 15 & 402.00 & 424 & 427 & 395 & 29 & 2 \\
\hline & & 6 & Drilled shaft & 35 & 15 & 401.00 & 423 & 425 & 395 & 28 & 9 \\
\hline & & 5 & Drilled shaft & 35 & 28 & 436.00 & $\mathrm{~d} 447$ & $\mathrm{~d} 447$ & 435 & 12 & $\mathrm{~d} 0$ \\
\hline \multirow{4}{*}{36} & \multirow{4}{*}{ L0135 } & 13 & Footing & 15 & 1 & -- & d351 & d351 & 345 & 6 & d0 \\
\hline & & 12 & Footing & 16 & 3 & -- & d321 & d322 & 317 & 2 & d0 \\
\hline & & 11 & Caisson & 24 & 1 & -- & 306 & 306 & 266 & 40 & 16 \\
\hline & & 10 & Caisson & 16 & 2 & -- & 330 & 330 & 245 & 85 & 8 \\
\hline \multirow{6}{*}{37} & \multirow{6}{*}{ A5076 } & 7 & Drilled shaft & 32 & 19 & 301.00 & (e) & (e) & 243 & (e) & (e) \\
\hline & & 6 & Drilled shaft & 32 & 20 & 292.00 & 311 & 312 & 245 & 66 & 4 \\
\hline & & 5 & Drilled shaft & 32 & 22 & 285.00 & 300 & 300 & 245 & 55 & 2 \\
\hline & & 4 & Caisson & 60 & 1 & -- & 285 & c285 & 244 & 41 & c14 \\
\hline & & 3 & Caisson & 67 & 1 & -- & 270 & c288 & 250 & 20 & c10 \\
\hline & & 2 & Footing & 60 & 1 & -- & (e) & (e) & 290 & $(\mathrm{e})$ & (e) \\
\hline
\end{tabular}


Table 7. Results near piers from surveys on the Missouri and Mississippi Rivers on the periphery of Missouri, from July 16 to August 13 , 2018.-Continued

[MoDOT, Missouri Department of Transportation; ft, foot; --, not known/applicable; all elevations are in feet above the North American Vertical Datum of 1988]

\begin{tabular}{|c|c|c|c|c|c|c|c|c|c|c|c|}
\hline \multirow[b]{2}{*}{$\begin{array}{c}\text { Site } \\
\text { number } \\
\text { (fig. 1) }\end{array}$} & \multirow[b]{2}{*}{$\begin{array}{c}\text { MoDOT } \\
\text { structure } \\
\text { number }\end{array}$} & \multirow[b]{2}{*}{$\begin{array}{l}\text { MoDOT } \\
\text { pier } \\
\text { number }\end{array}$} & \multicolumn{4}{|c|}{ Foundation information } & \multirow{2}{*}{$\begin{array}{l}\text { Approximate } \\
\text { minimum } \\
\text { elevation in } \\
\text { scour hole } \\
\text { near piera } \\
\text { (ft) }\end{array}$} & \multirow{2}{*}{$\begin{array}{l}\text { Approximate } \\
\text { elevation of } \\
\text { scour hole at } \\
\text { upstream } \\
\text { pier face } \\
\text { (ft) }\end{array}$} & \multirow[b]{2}{*}{$\begin{array}{l}\text { Approximate } \\
\text { elevation of } \\
\text { bedrock } \\
\text { near pier } \\
\text { (ft) }\end{array}$} & \multirow{2}{*}{$\begin{array}{c}\text { Approximate } \\
\text { distance } \\
\text { between bottom } \\
\text { of scour hole } \\
\text { and bedrock } \\
\text { (ft) }\end{array}$} & \multirow{2}{*}{$\begin{array}{c}\text { Depth } \\
\text { of scour } \\
\text { hole from } \\
\text { upstream } \\
\text { channel bed } \\
\text { (ft) }\end{array}$} \\
\hline & & & Type & $\begin{array}{c}\text { Width } \\
\text { (ft) }\end{array}$ & $\begin{array}{c}\text { Penetration } \\
\text { into bedrock } \\
\text { (ft) }\end{array}$ & $\begin{array}{l}\text { Seal course } \\
\text { or pile cap } \\
\text { bottom } \\
\text { elevation } \\
\text { (ft) }\end{array}$ & & & & & \\
\hline \multirow{8}{*}{38} & \multirow{8}{*}{ A1700 } & 21 & Caisson & 39 & 0 & f158.52 & 225 & 225 & -- & -- & d0 \\
\hline & & 20 & Caisson & 66 & 0 & f119.20 & 190 & 190 & -- & -- & c8 \\
\hline & & 19 & Caisson & 29 & 0 & f139.35 & 207 & c207 & -- & -- & c6 \\
\hline & & 18 & Pile cap & 50.8 & 0 & 188.00 & 212 & c212 & -- & -- & c0 \\
\hline & & 17 & Pile cap & 39.7 & 0 & 196.50 & 205 & 205 & -- & -- & 9 \\
\hline & & 16 & Pile cap & 42 & 0 & 196.50 & 196 & 200 & -- & -- & d0 \\
\hline & & 15 & Pile cap & 39.7 & 0 & 196.92 & d221 & d221 & -- & -- & d0 \\
\hline & & 14 & Pile cap & 18 & 0 & 240.00 & (e) & (e) & -- & -- & (e) \\
\hline
\end{tabular}

aThe point of lowest elevation in the scour hole near the bridge pier, not necessarily at the upstream pier face.

bScour hole at this pier was substantially affect by adjacent spur dike.

cPier appears to be partially or totally surrounded with a riprap blanket.

dScour hole at this pier is substantially affected by stone revetment or bedrock.

eUnable to obtain data because pier was in very shallow water.

fElevation of bottom of caisson is shown because it is not founded on bedrock. 

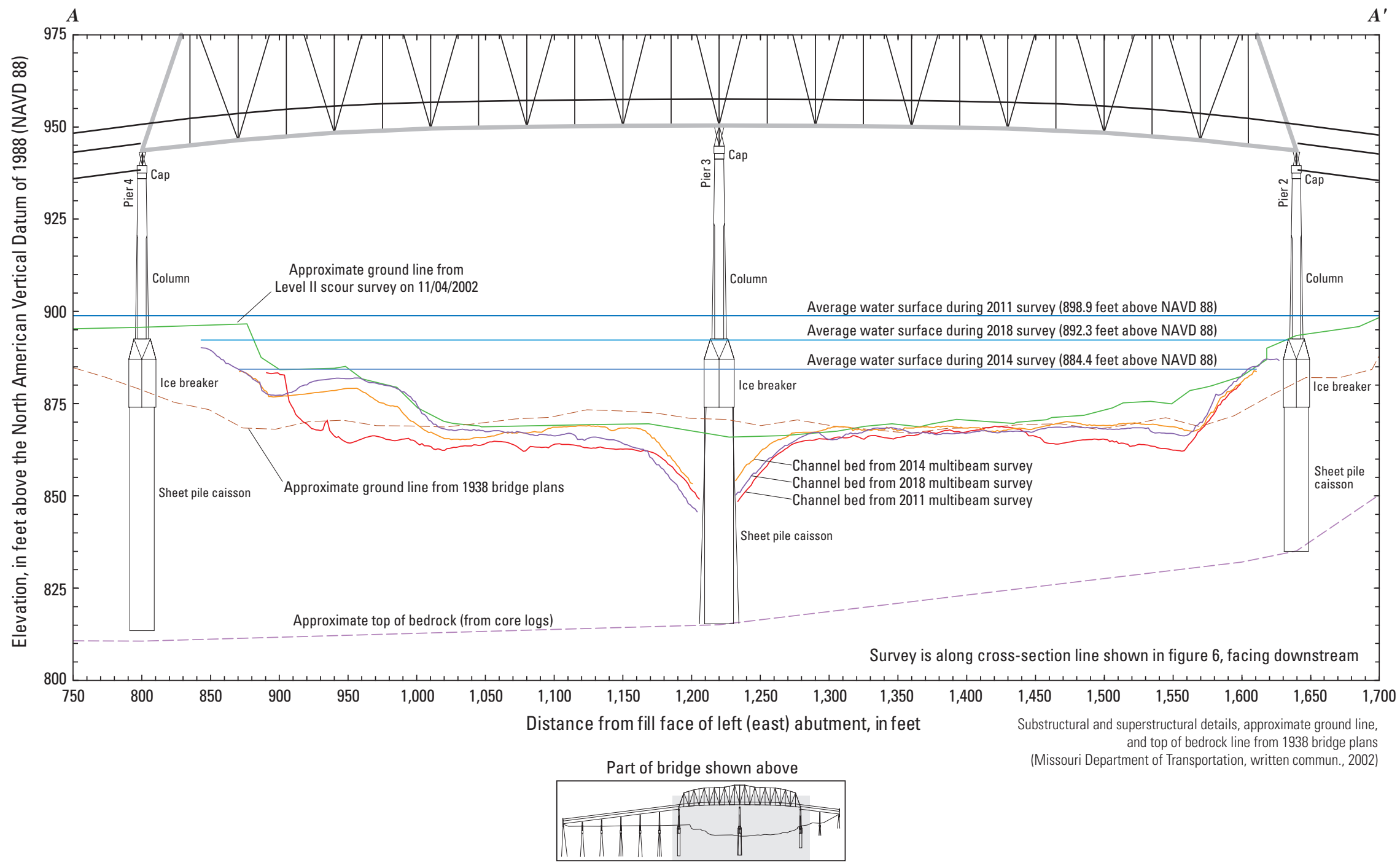

Figure 8. Key features, substructural and superstructural details, and surveyed channel bed of structure L0098 on U.S. Highway 136 over the Missouri River at Brownville, Nebraska. 
Table 8. Summary information and bathymetric surface difference statistics from surveys on the Missouri and Mississippi Rivers on the periphery of Missouri, from July 16 to August 13, 2018, and previous surveys.

[MoDOT, Missouri Department of Transportation; ft3/s, cubic feet per second; ft², square feet; ft, foot; Min, minimum; Max, maximum; A, Huizinga (2012); B, Huizinga (2015); all elevations are in feet above the North American Vertical Datum of 1988]

\begin{tabular}{|c|c|c|c|c|c|c|c|c|c|c|c|c|c|c|}
\hline \multirow[b]{2}{*}{$\begin{array}{l}\text { Site } \\
\text { number } \\
\text { (fig. 1) }\end{array}$} & \multirow[b]{2}{*}{$\begin{array}{l}\text { MoDOT } \\
\text { structure } \\
\text { number }\end{array}$} & \multicolumn{5}{|c|}{ Previous survey } & \multicolumn{3}{|c|}{$\begin{array}{l}\text { Difference between } 2018 \text { survey } \\
\text { and previous survey }\end{array}$} & \multicolumn{4}{|c|}{$\begin{array}{c}\text { Statistics of differences between } \\
2018 \text { and previous bathymetric survey } \\
\text { surfaces }\end{array}$} & \multirow{2}{*}{$\begin{array}{c}\text { Max } \\
\text { difference } \\
\text { near upstream } \\
\text { pier face }(\mathbf{s})^{\mathbf{b}, c} \\
\text { (ft) }\end{array}$} \\
\hline & & $\begin{array}{l}\text { Source } \\
\text { of data }\end{array}$ & Date & $\begin{array}{l}\text { Streamflow } \\
\left(\mathrm{ft}^{3} / \mathrm{s}\right)\end{array}$ & $\begin{array}{l}\text { Surveyed } \\
\text { area } \\
\left(x 1^{6} \mathrm{ft}^{2}\right)\end{array}$ & $\begin{array}{l}\text { Average } \\
\text { water- } \\
\text { surface } \\
\text { elevation } \\
\text { (ft) }\end{array}$ & $\begin{array}{l}\text { Streamflow } \\
\left(\mathrm{ft}^{3} / \mathrm{s}\right)\end{array}$ & $\begin{array}{l}\text { Surveyed } \\
\text { area } \\
\left(\times 10^{6} \mathrm{ft}^{2}\right)\end{array}$ & $\begin{array}{l}\text { Average } \\
\text { water- } \\
\text { surface } \\
\text { elevation } \\
\text { (ft) }\end{array}$ & $\begin{array}{c}\text { Mina,b } \\
\text { (ft) }\end{array}$ & $\begin{array}{c}\operatorname{Max}^{a, b} \\
(\mathrm{ft})\end{array}$ & $\begin{array}{l}\text { Average } \\
\text { (ft) }\end{array}$ & $\begin{array}{l}\text { Standard } \\
\text { deviation } \\
\text { (ft) }\end{array}$ & \\
\hline \multirow{2}{*}{1} & \multirow{2}{*}{ L0098 } & A & 07/13/11 & 225,000 & 1.159 & 898.9 & $-147,200$ & 0.069 & -6.6 & -33.3 & 36.3 & 3.77 & 3.40 & -1 \\
\hline & & B & 06/03/14 & 39,800 & 1.195 & 884.4 & 38,000 & 0.033 & 7.9 & -35.7 & 27.6 & 0.01 & 2.84 & -4 \\
\hline \multirow{2}{*}{2} & \multirow{2}{*}{$\begin{array}{c}\mathrm{A} 3664 \mathrm{E} \\
\text { \& W }\end{array}$} & A & 07/14/11 & 218,000 & 1.440 & 817.2 & $-121,900$ & 0.017 & -11.4 & -22.9 & 23.5 & 0.86 & 4.48 & 6 \\
\hline & & B & $06 / 04 / 14$ & 66,100 & $\mathrm{~d} 1.045$ & 799.8 & 30,000 & d0.412 & 6.0 & -15.9 & 28.0 & 3.15 & 4.49 & 14 \\
\hline 31 & A5054 & B & $06 / 05 / 14$ & 198,000 & 3.033 & 464.6 & $-25,000$ & 0.006 & -0.6 & -32.7 & 31.4 & 1.45 & 2.49 & 11 \\
\hline 36 & L0135 & B & 06/09/14 & 363,000 & 3.041 & 363.9 & $-73,000$ & 0.037 & -3.5 & -48.7 & 36.2 & 0.72 & 2.02 & -2 \\
\hline 37 & A5076 & B & 06/10/14 & 377,000 & 3.224 & 331.7 & $-95,000$ & -0.061 & -3.5 & -42.5 & 32.7 & 0.21 & 2.70 & 3 \\
\hline \multirow{3}{*}{38} & \multirow{3}{*}{ A1700 } & B & $12 / 10 / 08$ & 156,000 & e3.510 & 228.4 & 264,000 & e 0.806 & 17.5 & -29.1 & 47.2 & -3.98 & 9.43 & 13 \\
\hline & & B & 05/05/11 & $2,040,000$ & 4.281 & 277.4 & $-1,620,000$ & 0.035 & -31.5 & -54.2 & 48.7 & 5.83 & 8.19 & 5 \\
\hline & & B & $06 / 11 / 14$ & 629,000 & 4.418 & 251.8 & $-209,000$ & -0.102 & -5.9 & -59.2 & 42.6 & -3.37 & 8.01 & 3 \\
\hline
\end{tabular}

bA positive value represents deposition, a negative value represents scour.

cThe maximum difference near the upstream pier face was taken near the location of the "approximate elevation of scour hole at upstream pier face" in table 7.

dThe surveyed reach in 2014 was narrower because of a wide band of floating debris along the right bank.

eThe surveyed reach in 2008 was narrower and shorter in length because of lower flow conditions and not surveying as high on banks. 
U.S. Geological Survey boat collecting bathymetric data

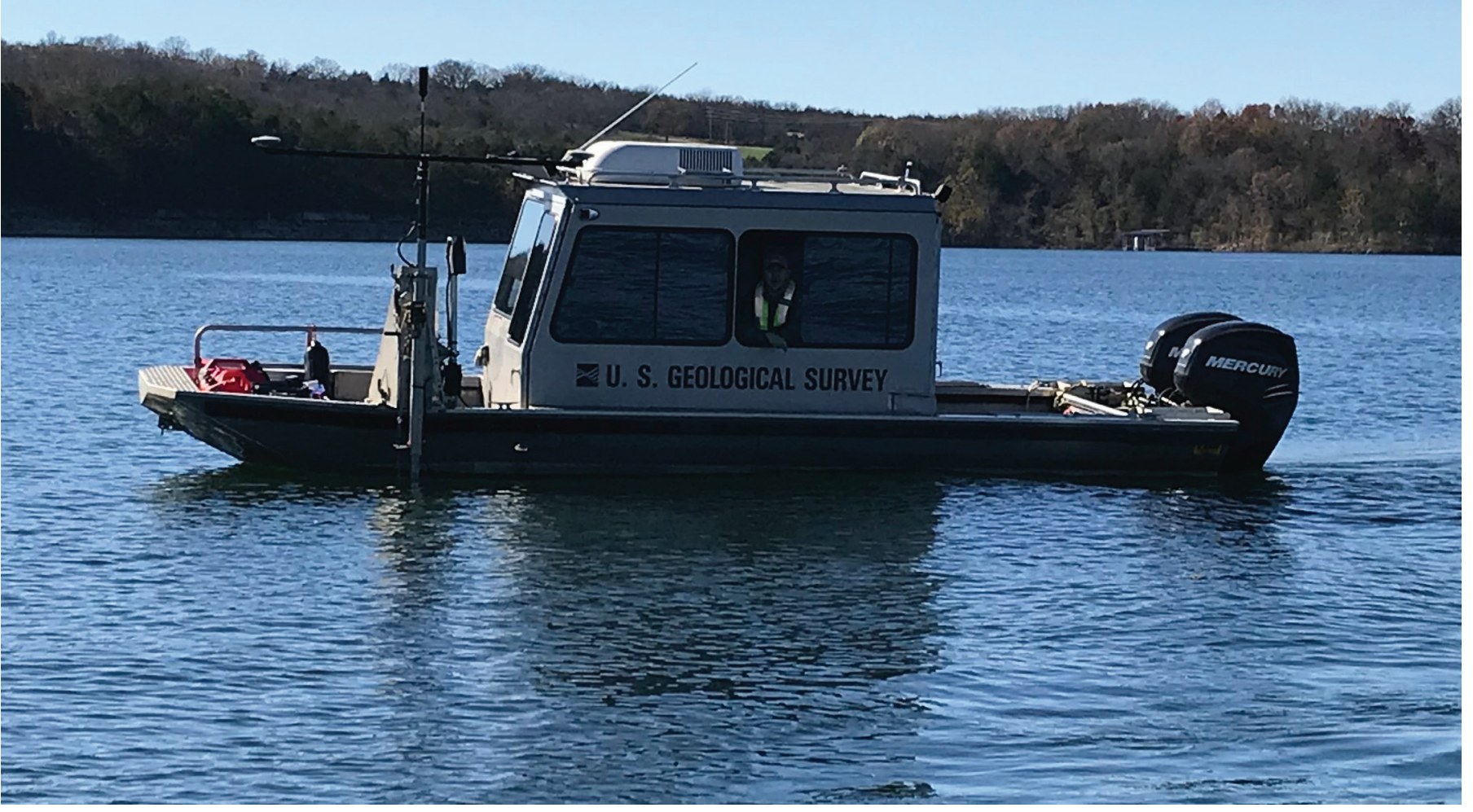




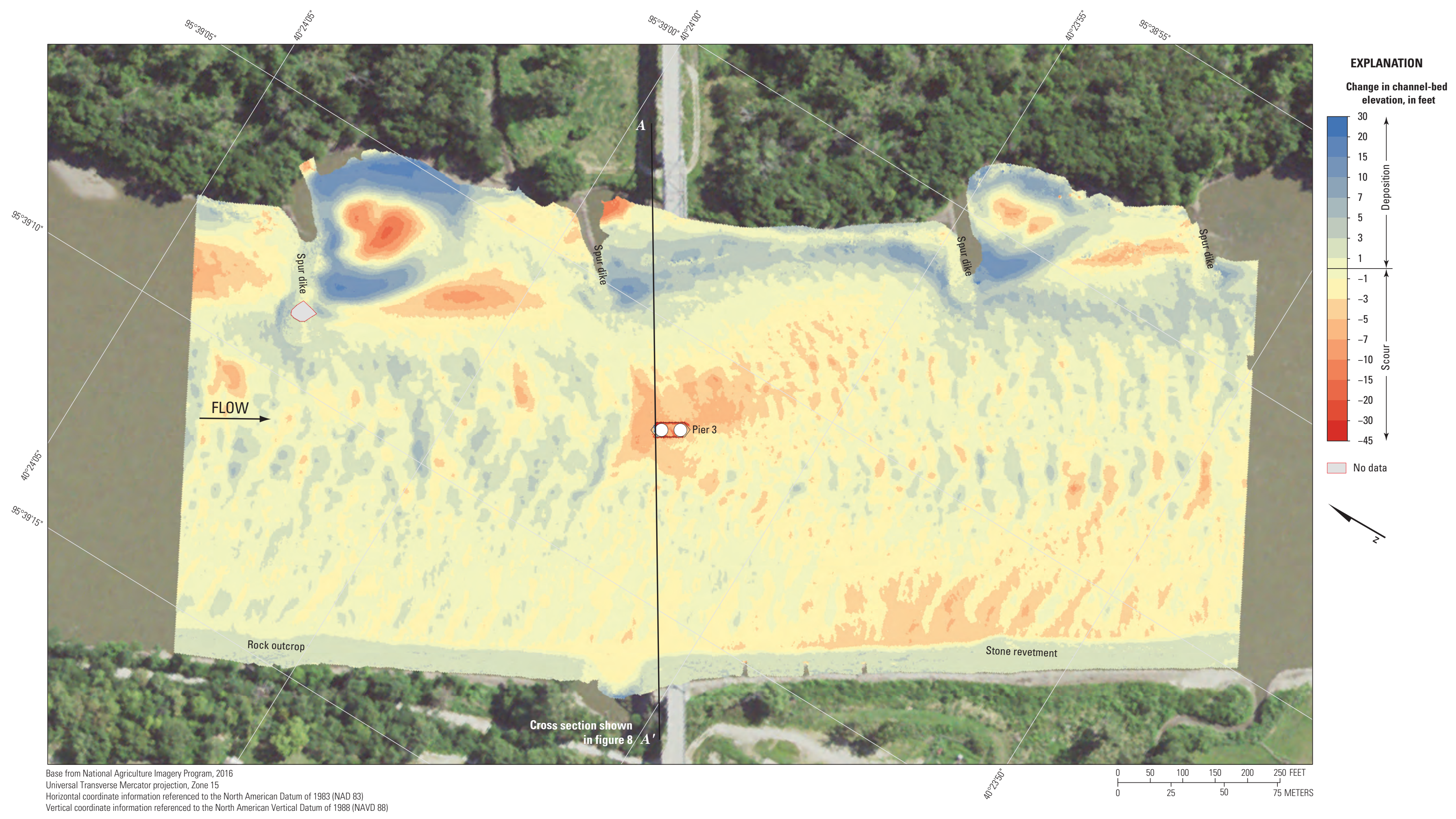

Figure 9. Difference between surfaces created from bathymetric surveys of the Missouri River channel near structure L0098 on U.S.

Highway 136 at Brownville, Nebraska, on August 13, 2018, and June 3, 2014. 


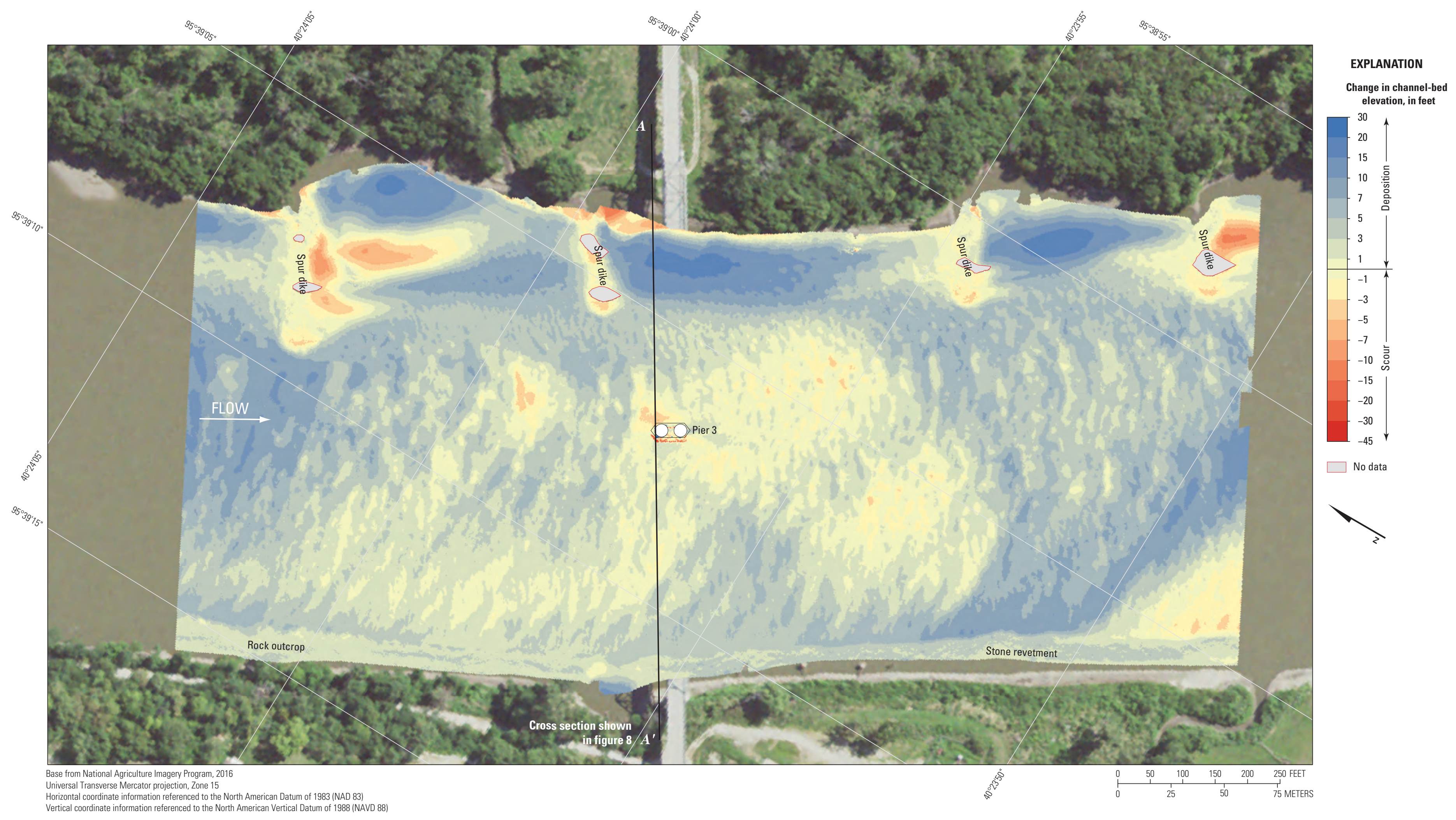

Figure 10. Difference between surfaces created from bathymetric surveys of the Missouri River channel near structure L0098 on U.S. Highway 136 at Brownville, Nebraska, on August 13, 2018, and July 13, 2011. 


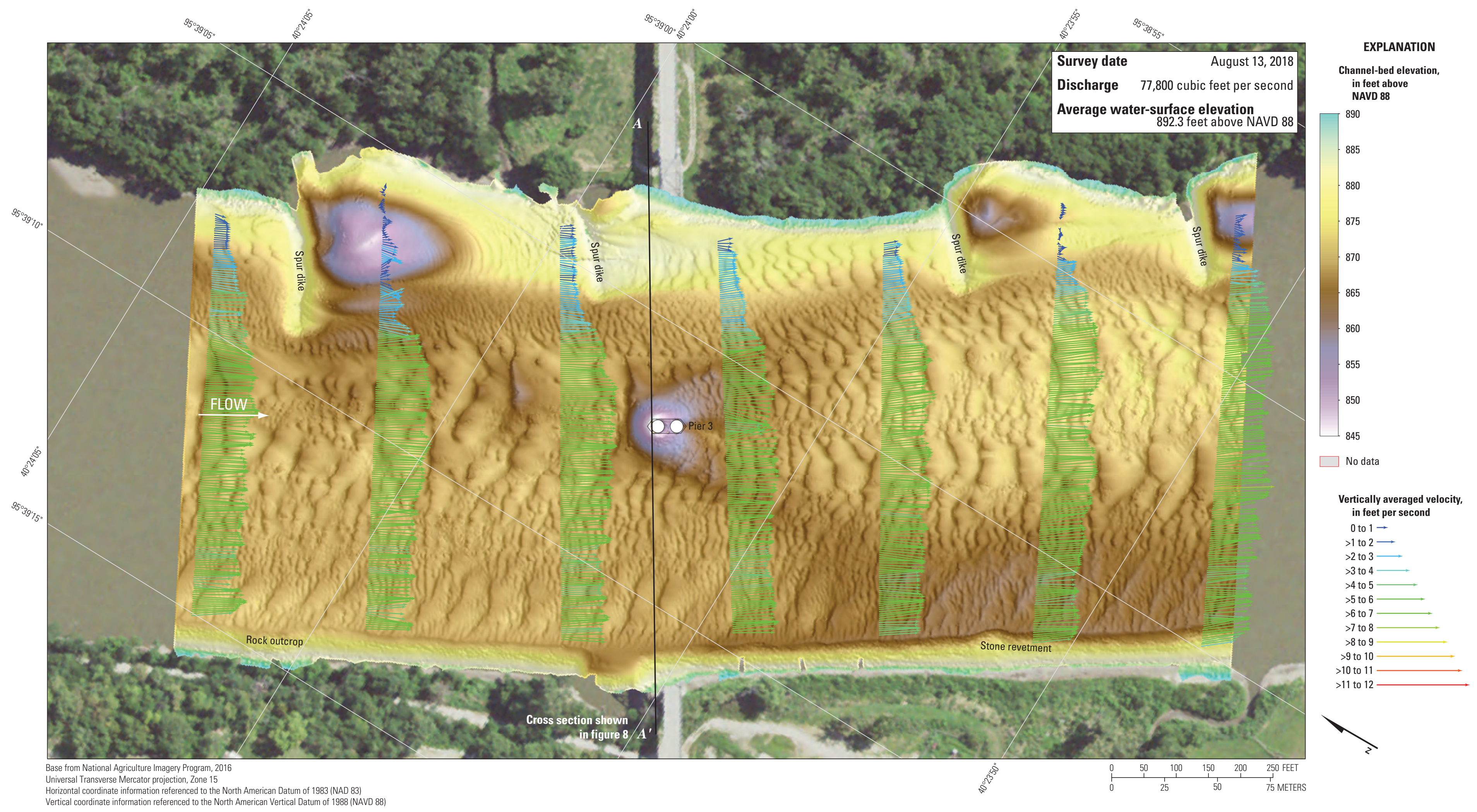

Figure 11. Bathymetry and vertically averaged velocities of the Missouri River channel near structure L0098 on U.S. Highway 136 at Brownville, Nebraska. 


\section{Dual Bridge Structure A3664 on U.S. Highway 36 at St. Joseph, Missouri}

Structure A3664 (site 2) consists of twin bridges on U.S. Highway 36 crossing the Missouri River at RM 447.9 at St. Joseph, Mo., on the western side of Missouri north of Kansas City (fig. 1). The site was surveyed on July 16, 2018, and the average water-surface elevation near the bridge, determined by the RTK GNSS tide solution, was $805.8 \mathrm{ft}$ (table 3). Flow on the Missouri River was about 96,100 ft3/s during the survey (table 3).

The survey area was about 1,640 ft long and about $880 \mathrm{ft}$ wide, extending from bank to bank in the main channel (fig. 12). The upstream end of the survey area was about $655 \mathrm{ft}$ upstream from the centerline of structure A3664, and piers 8 through 11 were in the water, but piers 9 and 10 were away from the banks (fig. 12). The approximate channel-bed elevations ranged from about 774 to $795 \mathrm{ft}$ for most of the surveyed area (5th to 95th percentile range of the bathymetric data; table 3; fig. 13), except near the spur dikes on the right (west) bank (fig. 12; table 3). The channel bed between the left (east) bank and the spur dikes was filled with small to medium dune features, and small dunes and ripples were present in the area between the spur dikes on the right (west) side of the channel (fig. 12). Substantial scour holes were present downstream from the spur dikes on the right (west) side (fig. 12). Stone revetment was present on the left (east) bank throughout the reach (fig. 12).

The minor scour hole near pier 10 was difficult to discern from nearby dunes and ripples (figs. 12, 1.2A, 1.2B), but had a minimum channel-bed elevation of about $777 \mathrm{ft}$ (table 7). The top of the footing of pier 9 was evident on the upstream and left (east) sides, primarily because of the scour hole from the upstream spur dike (figs. 12, 1.2C, 1.2D). Information from bridge plans indicates that piers 9 and 10 are founded on shafts drilled into bedrock, with about $24 \mathrm{ft}$ of bed material between the bottom of the scour hole and bedrock at the upstream face of pier 9 (table 7). The surveyed bed was generally similar to the multibeam survey on July 14, 2011, except on the left side of pier 10 (fig. 14).

The difference between the survey on July 16, 2018, and the previous nonflood survey on June 4, 2014 (fig. 15), indicates substantial deposition of nearly $30 \mathrm{ft}$ throughout the reach from the 2014 to 2018 surveys, resulting in an average difference of $+3.15 \mathrm{ft}$ between the bathymetric surfaces (table 8). The net volume of cut in the reach from 2014 to 2018 was about 21,200 $\mathrm{yd}^{3}$, and the net volume of fill was about $141,200 \mathrm{yd}^{3}$, resulting in a net gain of about $120,000 \mathrm{yd}^{3}$ of sediment. The frequency distribution of channel-bed elevations in 2018 was similar in shape to 2014, but with most of the survey-grid cells at elevations about $3 \mathrm{ft}$ higher than in 2014 (fig. 13). The limited width extent of the 2014 survey

\section{Dual Bridge Structure A3664 on U.S. Highway 36}


may affect the difference, as areas of erosion or deposition downstream from the spur dikes were not surveyed in 2014. Furthermore, a dredge barge was in operation near the downstream end of the surveyed reach in 2014 (see fig. 10 in Huizinga, 2015), and the dredging activity may have created overall scour in the reach in 2014 as sediment shifted to fill the downstream area being dredged. The dredge activity in 2014 may explain the generally lower cross section at the upstream bridge face in 2014 (fig. 14), as well as the lower elevations observed for 2014 in the frequency distribution and accumulation curve (fig. 13).

The difference between the survey on July 16, 2018, and the previous flood survey on July 14, 2011, indicates a general balance of scour and deposition throughout the reach between 2011 and 2018, except downstream from the downstream spur dike on the right (west) side of the channel where scour of as much as $20 \mathrm{ft}$ was observed (fig. 16). The average difference between the bathymetric surfaces was $+0.86 \mathrm{ft}$ (table 8), indicating minor aggradation between the 2011 and 2018 surveys for the area common to both surveys. The net volume of cut in the reach from 2011 to 2018 was about 63,500 $\mathrm{yd}^{3}$, and the net volume of fill was about $108,400 \mathrm{yd}^{3}$, resulting in a net gain of about $44,900 \mathrm{yd}^{3}$ of sediment. The frequency distribution of channel-bed elevations in 2018 was similar to 2011, with a slightly higher percentage of survey-grid cells at elevations between 780 and $785 \mathrm{ft}$ in 2018 compared to 2011 (fig. 13). The stone revetment on the left (east) bank showed no signs of substantial change between the 2018 survey and both previous surveys (figs. 15, 16).

The vertically averaged velocity vectors indicate mostly uniform flow throughout the reach (fig. 17). A maximum velocity of about $9 \mathrm{ft} / \mathrm{s}$ was present in the left (eastern) side of the channel and a minimum of $1 \mathrm{ft} / \mathrm{s}$ with flow reversal was present downstream from the various spur dikes in the reach (fig. 17). Minimal to moderate turbulence was observed at several transects (fig. 17), likely as a result of localized flow disturbances caused by the spur dikes and bedforms. The bridge piers were aligned with flow, with only moderate effects on the velocity and no evident turbulence downstream from either in-channel pier (fig. 17). 


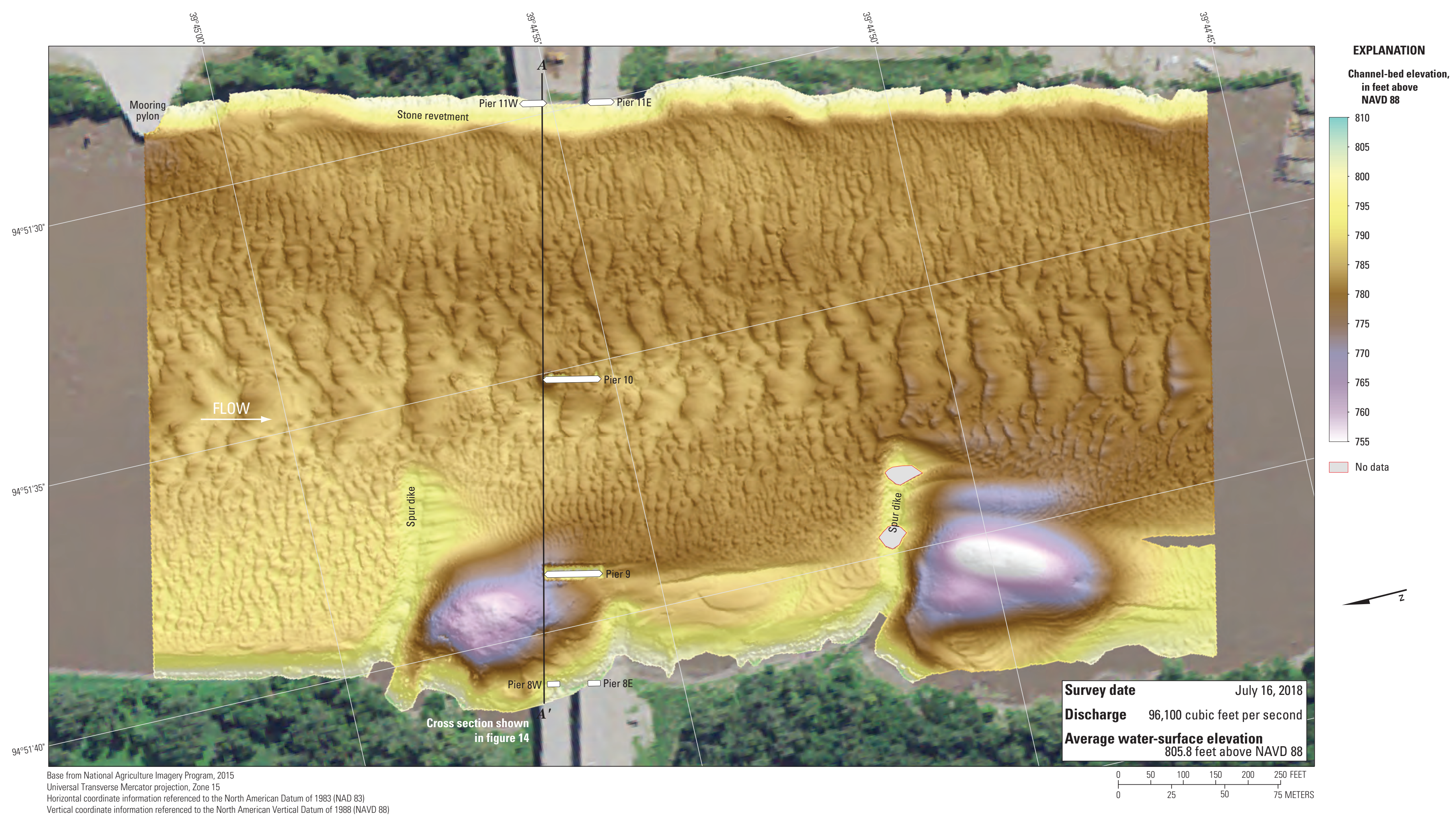

Figure 12. Bathymetric survey of the Missouri River channel near dual bridge structure A3664 on U.S. Highway 36 at St. Joseph, 

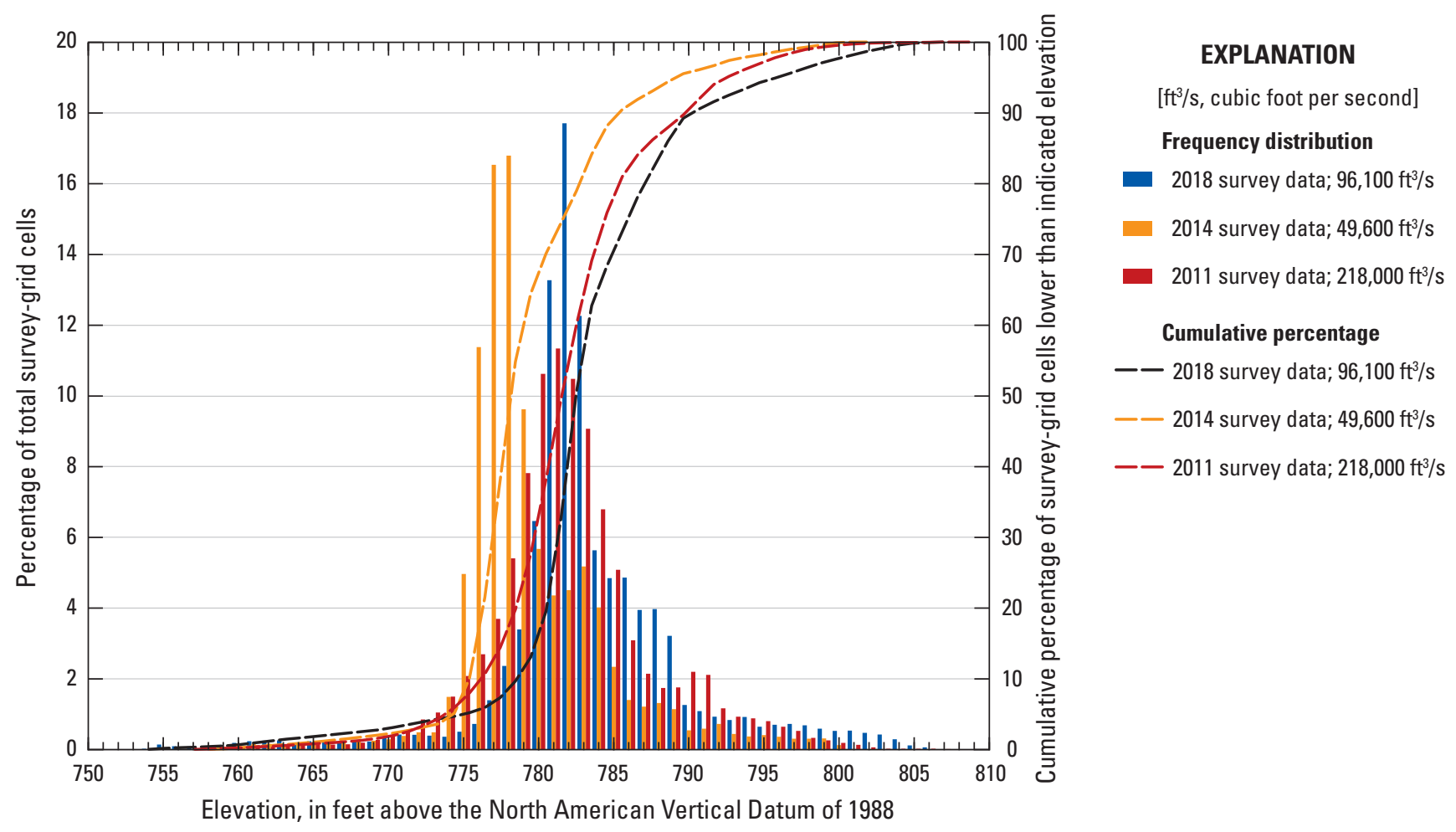

Figure 13. Frequency distribution of bed elevations for bathymetric survey-grid cells in 1-foot elevation bins on the Missouri River near dual bridge structure A3664 on U.S. Highway 36 at St. Joseph, Missouri, on July 16, 2018, compared to previous surveys (Huizinga, 2012, 2015). 


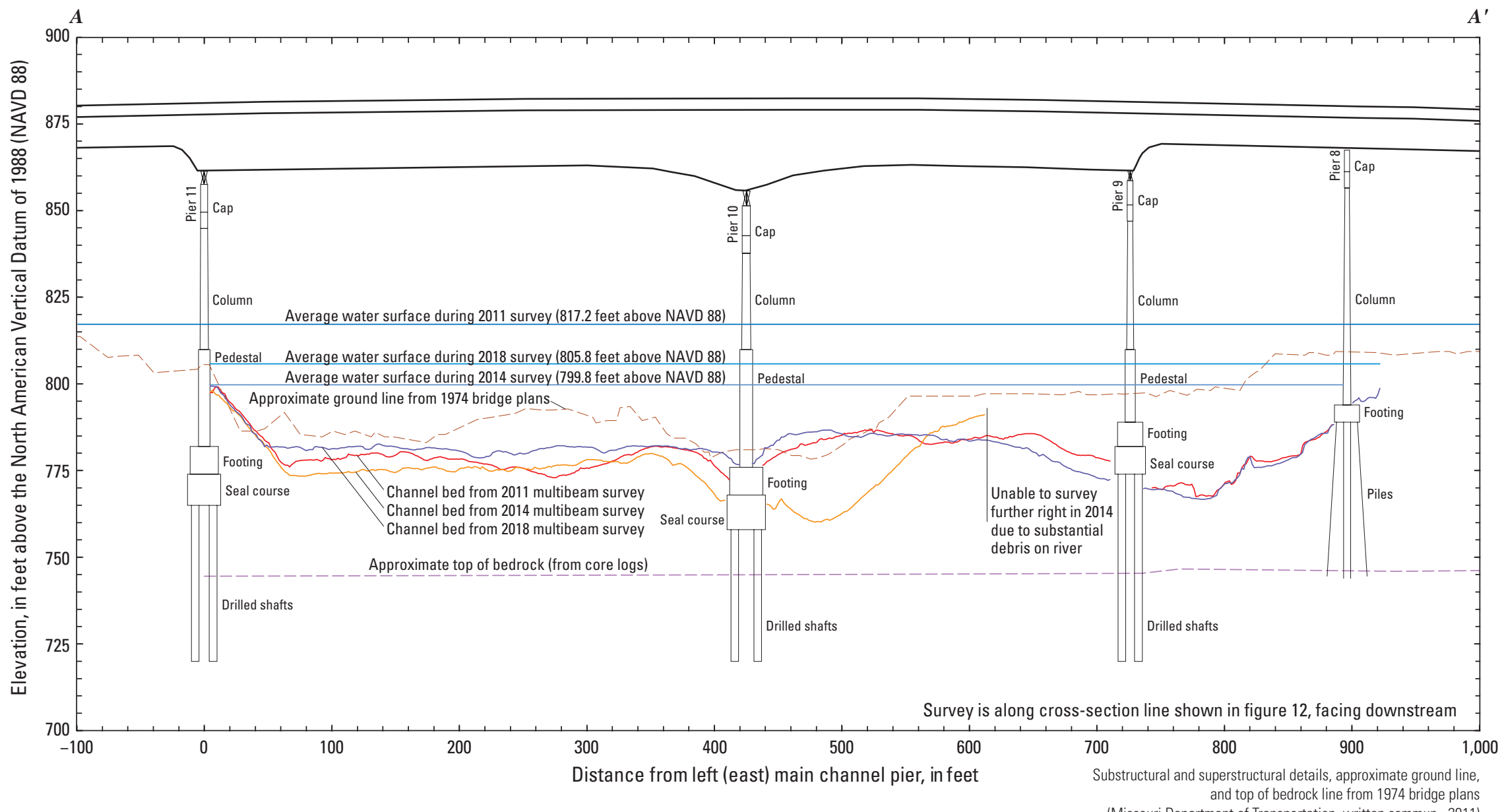

Part of bridge shown above

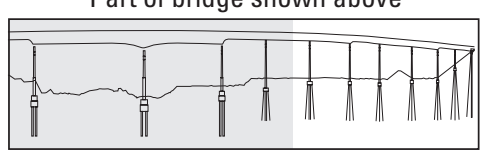

Figure 14. Key features, substructural and superstructural details, and surveyed channel bed of dual bridge structure A3664 on U.S. Highway 36 crossing the Missouri River at St. Joseph, Missouri. 


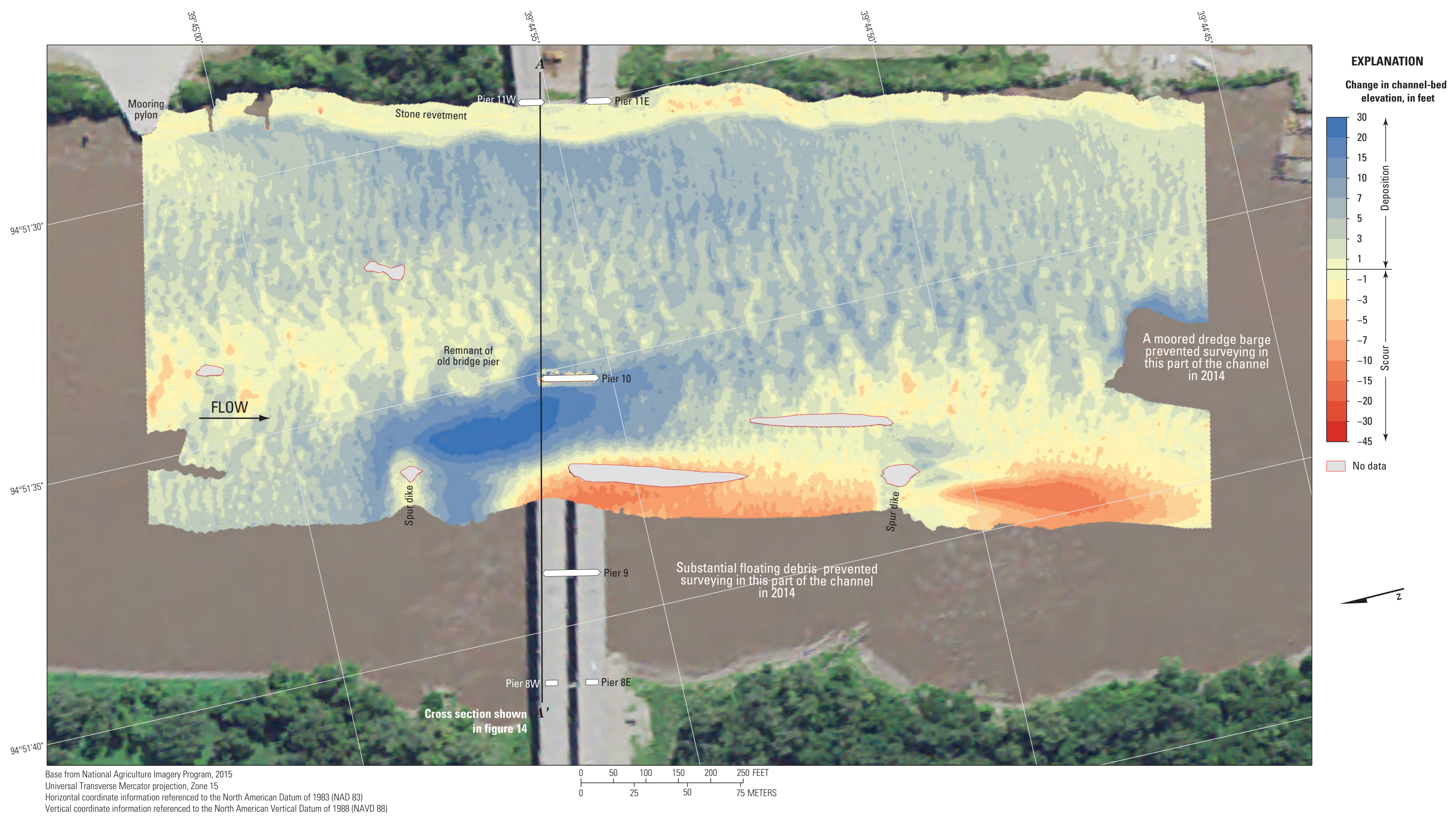

Figure 15. Difference between surfaces created from bathymetric surveys of the Missouri River channel near dual bridge structure A3664 on U.S. Highway 36 at St. Joseph, Missouri, on July 16, 2018, and June 4, 2014. 


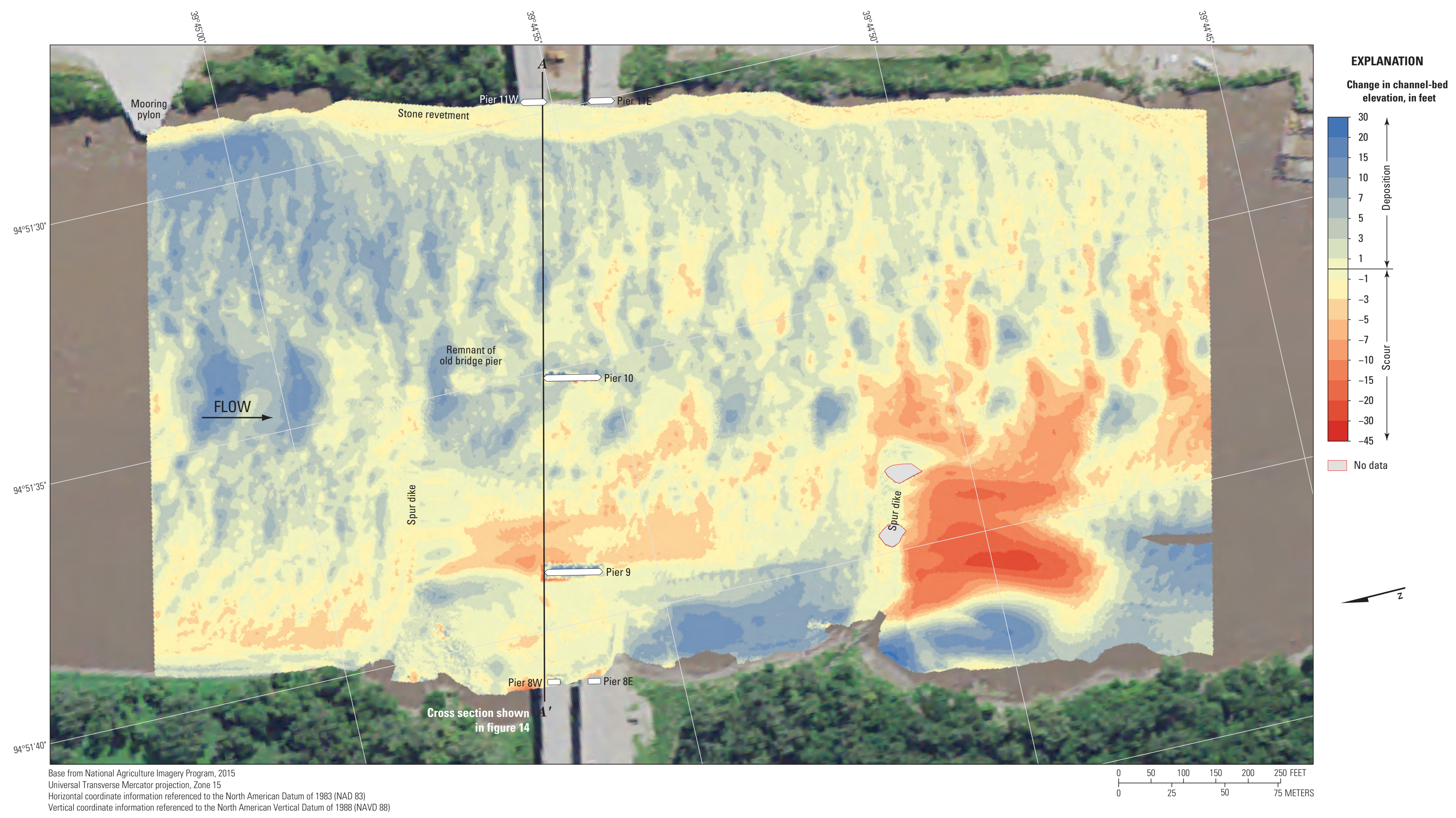

Figure 16. Difference between surfaces created from bathymetric surveys of the Missouri River channel near dual bridge structure A3664 on U.S. Highway 36 at St. Joseph, Missouri, on July 16, 2018, and July 14, 2011. 


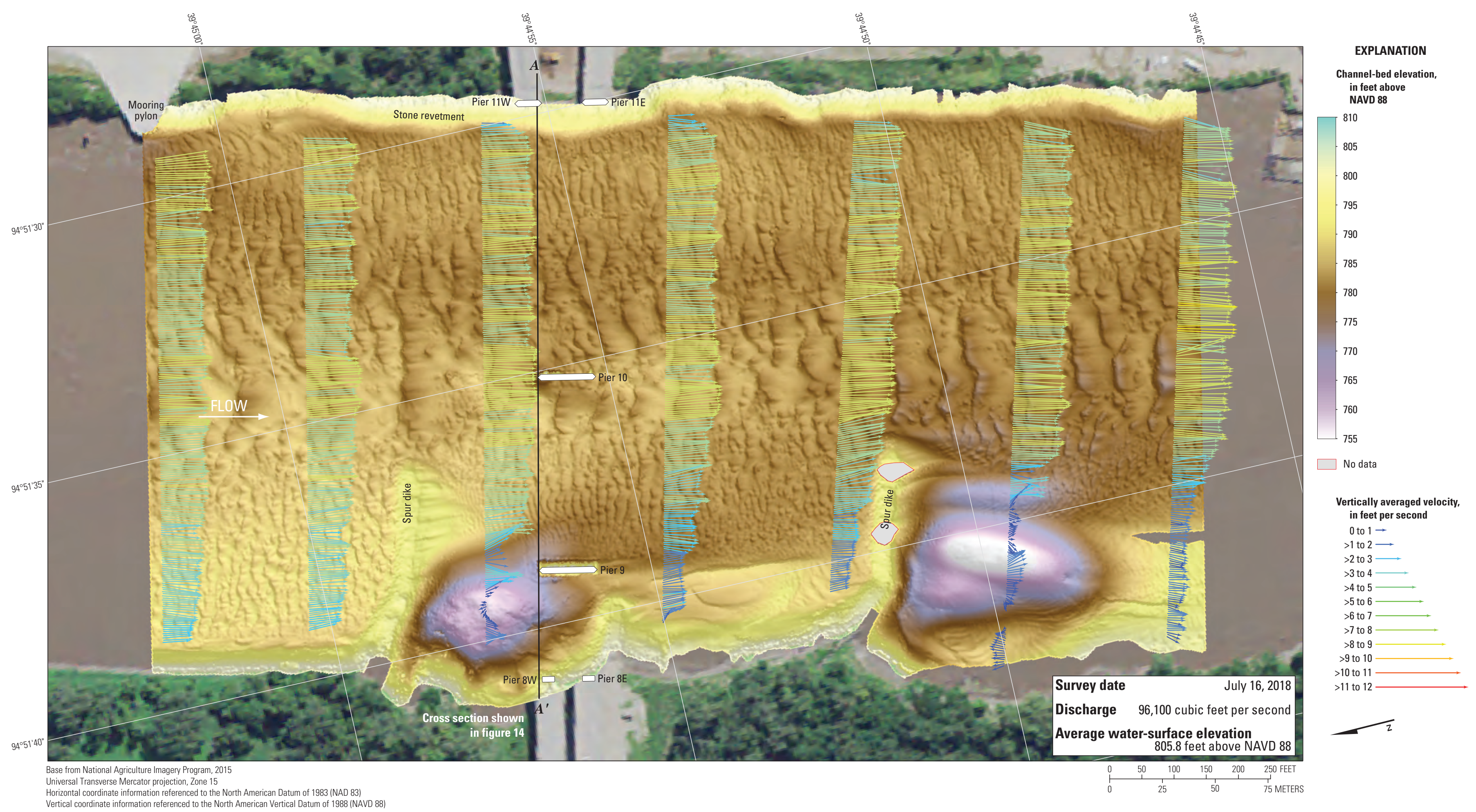

Figure 17. Bathymetry and vertically averaged velocities of the Missouri River channel near dual bridge structure A3664 on U.S. Highway 36 at St. Joseph, Missouri. 


\section{Sites on the Mississippi River}

There are four unique highway crossings of the Mississippi River upstream from St. Louis, and five unique highway crossings of the Mississippi River downstream from St. Louis (table 2; fig. 1). Five of these Mississippi River crossings are maintained by MoDOT, and four were surveyed as part of this study; structure K093 (site 32) on U.S. Highway 54 at Louisiana was being replaced in 2018 and was not surveyed. Bathymetry and velocity data from the four surveys from the current (2018) study are included with metadata in Huizinga (2020d). Bathymetry data from earlier surveys at all five crossings maintained by MoDOT also are included with metadata in Huizinga (2020d).

\section{Structure A5054 on Interstate 72 at Hannibal, Missouri}

Structure A5054 (site 31) on Interstate 72 crosses the upper Mississippi River at RM 309.5 at Hannibal, Mo., north of St. Louis, Mo., and south of Quincy, Ill. (fig. 1; table 2). The site was surveyed on July 18, 2018, and the average water-surface elevation of the river in the survey area, determined by the RTK GNSS tide solution, was $464.0 \mathrm{ft}$ (table 3). Streamflow on the Mississippi River was about 173,000 ft3/s during the survey (table 3).
The survey area was about 1,640 ft long and about $1,870 \mathrm{ft}$ wide, extending across the active channel from the left (northeast) bank to the right (southwest) bank (fig. 18). The upstream end of the survey area was about $700 \mathrm{ft}$ upstream from the centerline of structure A5054, and piers 5 through 11 were in the water; however, pier 5 was in shallow water on the right bank. The channel-bed elevations ranged from about 429 to $449 \mathrm{ft}$ for most of the surveyed area (5 to 95 percentile range of the bathymetric data; table 3; fig. 19), except near pier 6 through 8 and the thalweg of the channel along the base of the right (southwest) bank (table 3; fig. 20). The left side of the channel between the left bank and the channel thalweg was filled with small and medium dune features with superimposed ripples, and small dunes and ripples were present in the thalweg. A spur dike on the downstream left side was barely visible above the average bed nearby. The right bank seems to consist of smooth rock or hardpan clay throughout the reach, with no discernable dune features (fig. 18).

The minor scour holes near piers 10 and 11 were difficult to discern from nearby dunes and ripples, and there was no discernable hole near pier 5 on the right bank (figs. 18, 20). Alternatively, piers 6 through 8 had well-defined, asymmetric scour holes indicative of being skewed to approach flow. Pier 8 seems to have part of the footing exposed in the bathymetric map (figs. 18, 1.4A, 1.4B), and piers 9 and 10 seem to be surrounded by partial riprap blankets or piles of rock (figs. 18, 1.3C through 1.3F). Information from bridge plans

\section{Structure A5054 on Interstate 72}

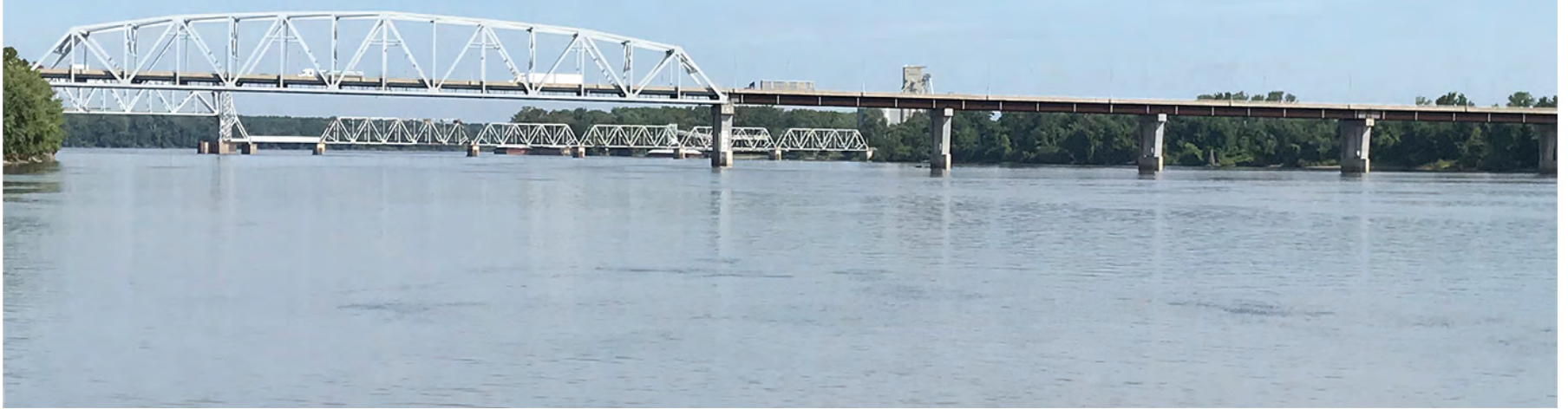


(Missouri Department of Transportation, written commun., 2014) indicates that piers 5 through 8 are founded on shafts drilled 15 to $28 \mathrm{ft}$ into bedrock, having about 12 to $34 \mathrm{ft}$ of bed material between the channel bottom and bedrock (fig. 20; table 7). Piers 9 through 11 are founded on steel H-piles driven to refusal on bedrock, having $56 \mathrm{ft}$ of bed material between the channel bottom and bedrock at pier $9,86 \mathrm{ft}$ of bed material at pier 10, and $89 \mathrm{ft}$ of bed material at pier 11 (fig. 20; table 7). The surveyed bed was 1 to $10 \mathrm{ft}$ higher along the upstream bridge face than the previous survey in 2014, except between the left (northeast) bank and pier 10 (fig. 20). The cross section along the upstream bridge face indicates partial footing exposure at all the piers (fig. 20), although it is not readily evident on the bathymetry map (fig. 18). However, footing exposure is readily apparent in the shaded TIN images of pier 11 (figs. 1.3A, 1.3B) and piers 6 through 8 (fig. 1.4). The top of the footing is partially evident at pier 9 in the shaded TIN images (figs. 1.3F), but is mostly obscured by sediment or a partial riprap blanket.

The difference between the survey on July 18, 2018, and the previous survey on June 5, 2014 (fig. 21), indicates moderate deposition of as much as $15 \mathrm{ft}$ throughout the reach from the 2014 to 2018 surveys, resulting in an average difference of $+1.45 \mathrm{ft}$ between the bathymetric surfaces (table 8 ). The net volume of cut in the reach from 2014 to 2018 was about $39,800 \mathrm{yd}^{3}$, and the net volume of fill was about $200,000 \mathrm{yd}^{3}$, resulting in a net gain of about $160,000 \mathrm{yd}^{3}$ of sediment. There was minor deposition of as much as $5 \mathrm{ft}$ along the right (southwest) bank, and a narrow bank of scour of as much as $10 \mathrm{ft}$ along the left (northeast) bank compared to the 2018 survey (fig. 21). Moderate localized scour of as much as $10 \mathrm{ft}$ was observed in various areas upstream, near the bridge piers, and downstream in the channel (fig. 21). The frequency distribution of bed elevations was similar in 2018 and 2014, but with a greater percentage of survey-grid cells at elevations below $432 \mathrm{ft}$ in 2014 than 2018 (fig. 19).

The vertically averaged velocity vectors indicate mostly uniform flow throughout most of the channel, ranging from about 3 to 7 ft/s (fig. 22). Areas of non-uniform flow caused by the skewed orientation of the piers is evident in the velocity sections downstream from the bridge, as well as near the spur dike on the left bank downstream from the bridge. Similar areas of non-uniform flow are apparent in the upstream sections as well, likely caused by a railroad bridge located about $1,130 \mathrm{ft}$ upstream from the surveyed reach (fig. 22) 


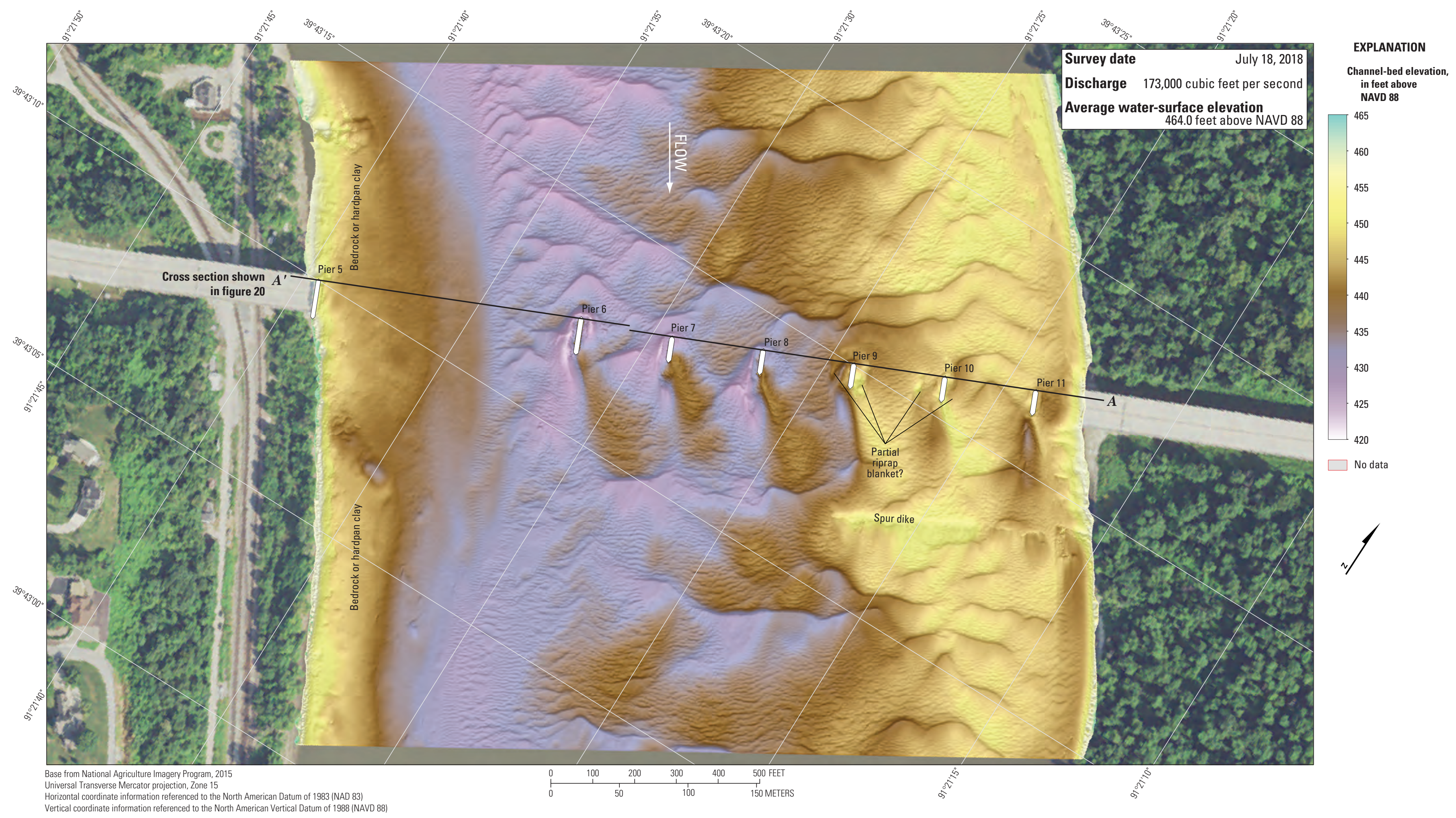

Figure 18. Bathymetric survey of the Mississippi River channel near structure A5054 on Interstate 72 at Hannibal, Missouri. 

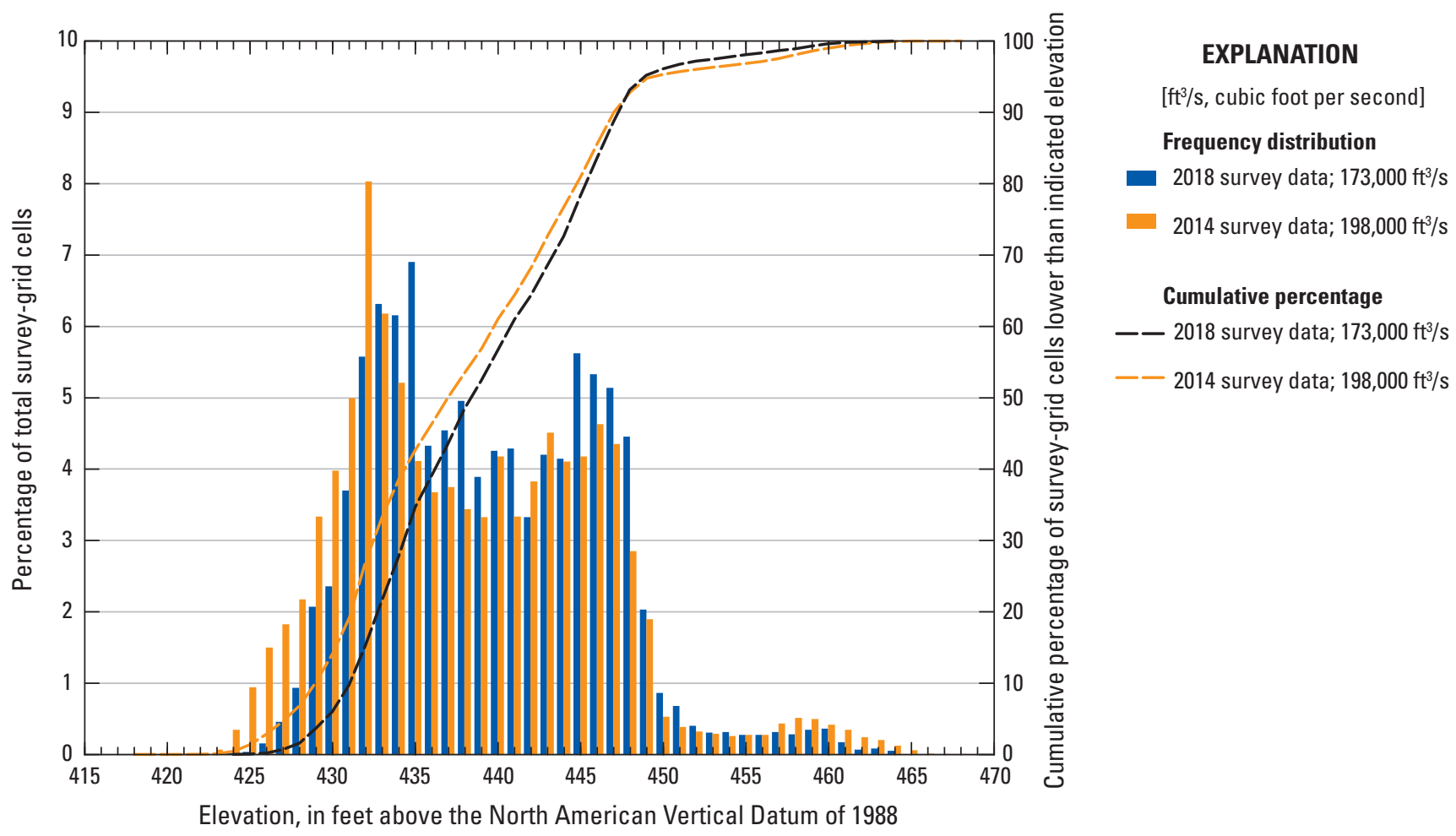

Figure 19. Frequency distribution of bed elevations for bathymetric survey-grid cells in 1-foot elevation bins on the Mississippi River near structure A5054 on Interstate 72 at Hannibal, Missouri, on July 18, 2018, compared to previous surveys (Huizinga, 2015). 


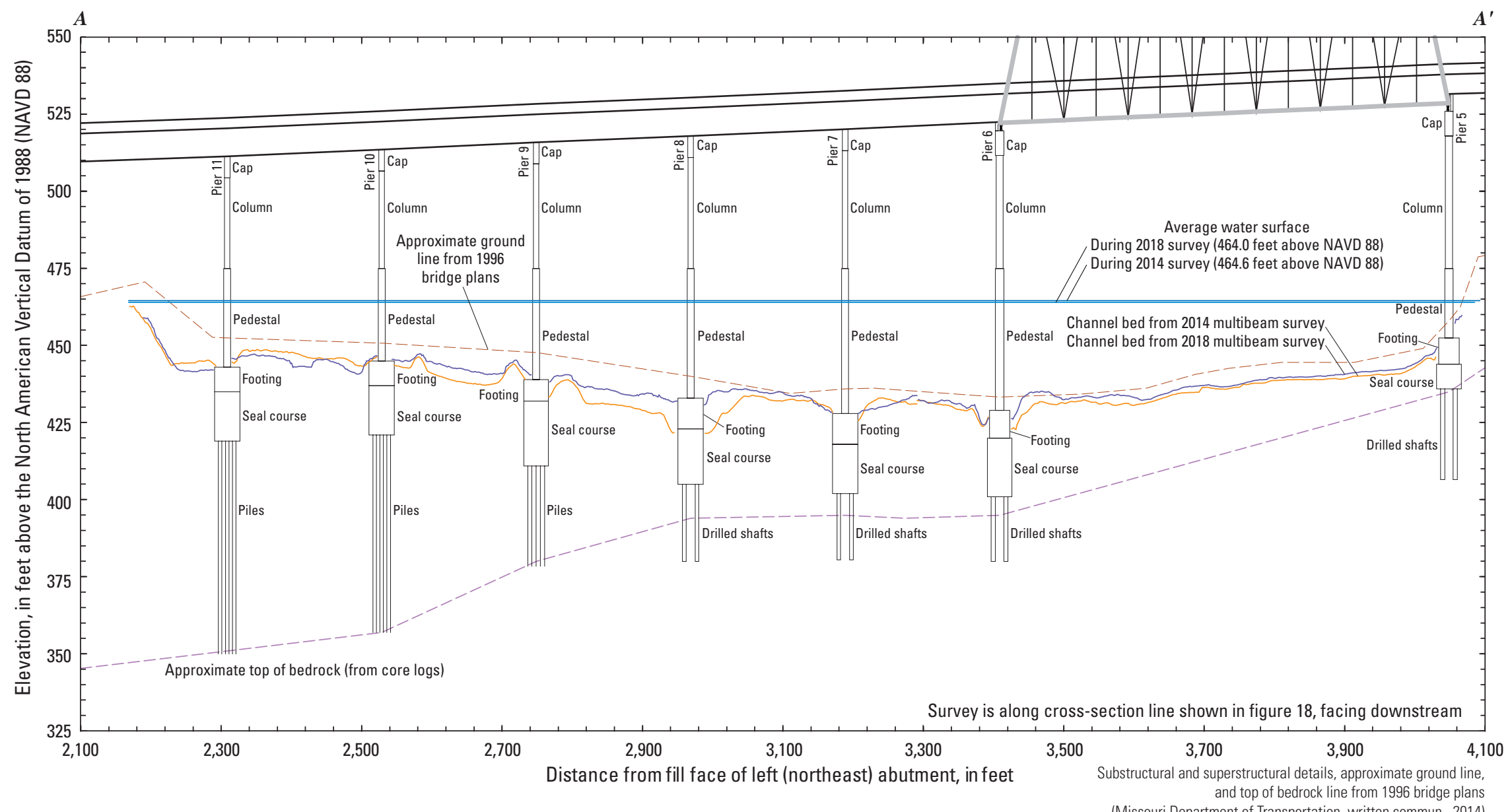

Part of bridge shown above

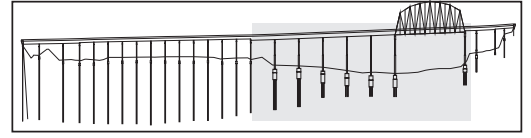

Figure 20. Key features, substructural and superstructural details, and surveyed channel bed of structure A5054 on Interstate 72 crossing the Mississippi River at Hannibal, Missouri. 


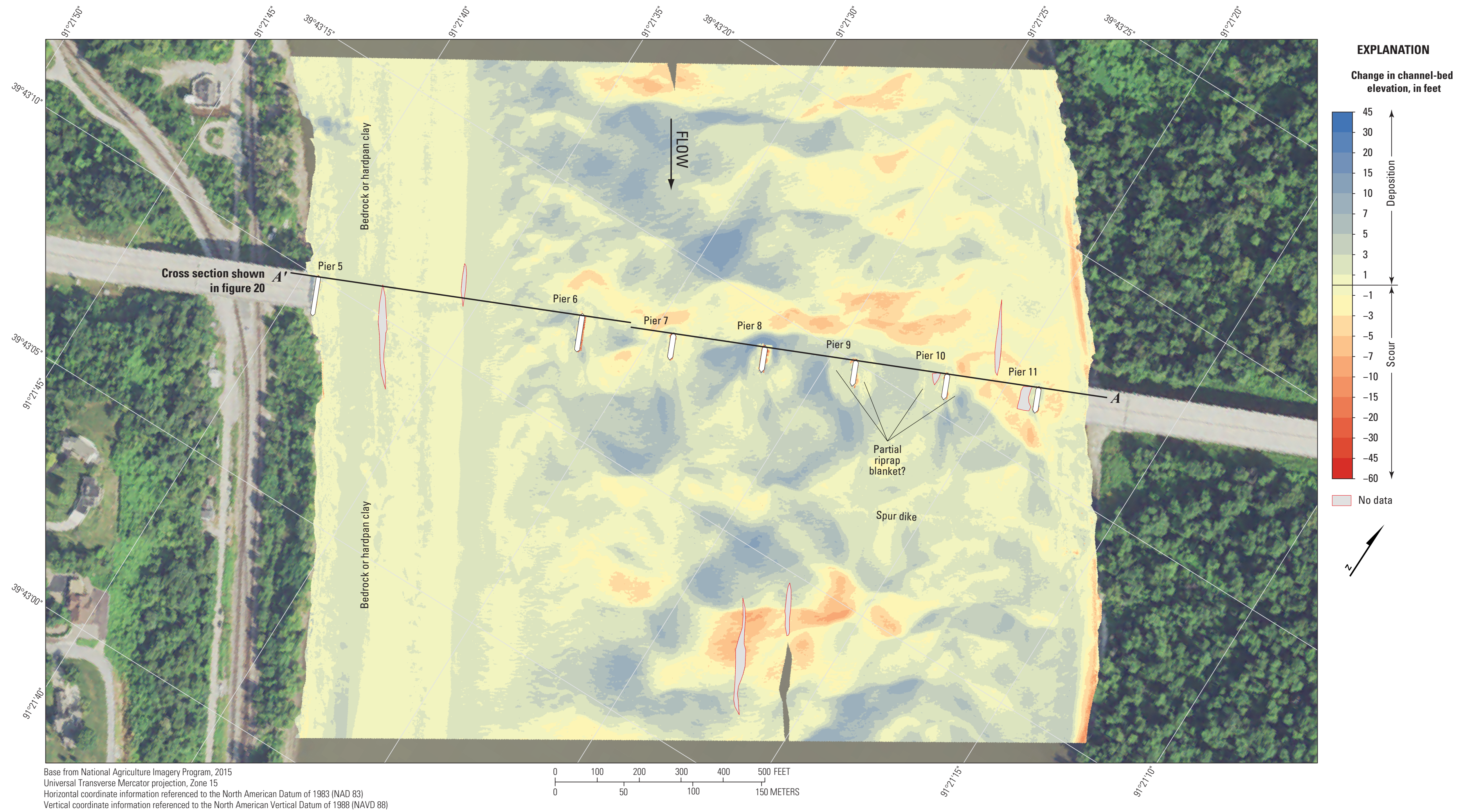

Figure 21. Difference between surfaces created from bathymetric surveys of the Mississippi River channel near structure A5054 on Interstate 72 at Hannibal, Missouri, on July 18, 2018, and June 5, 2014. 


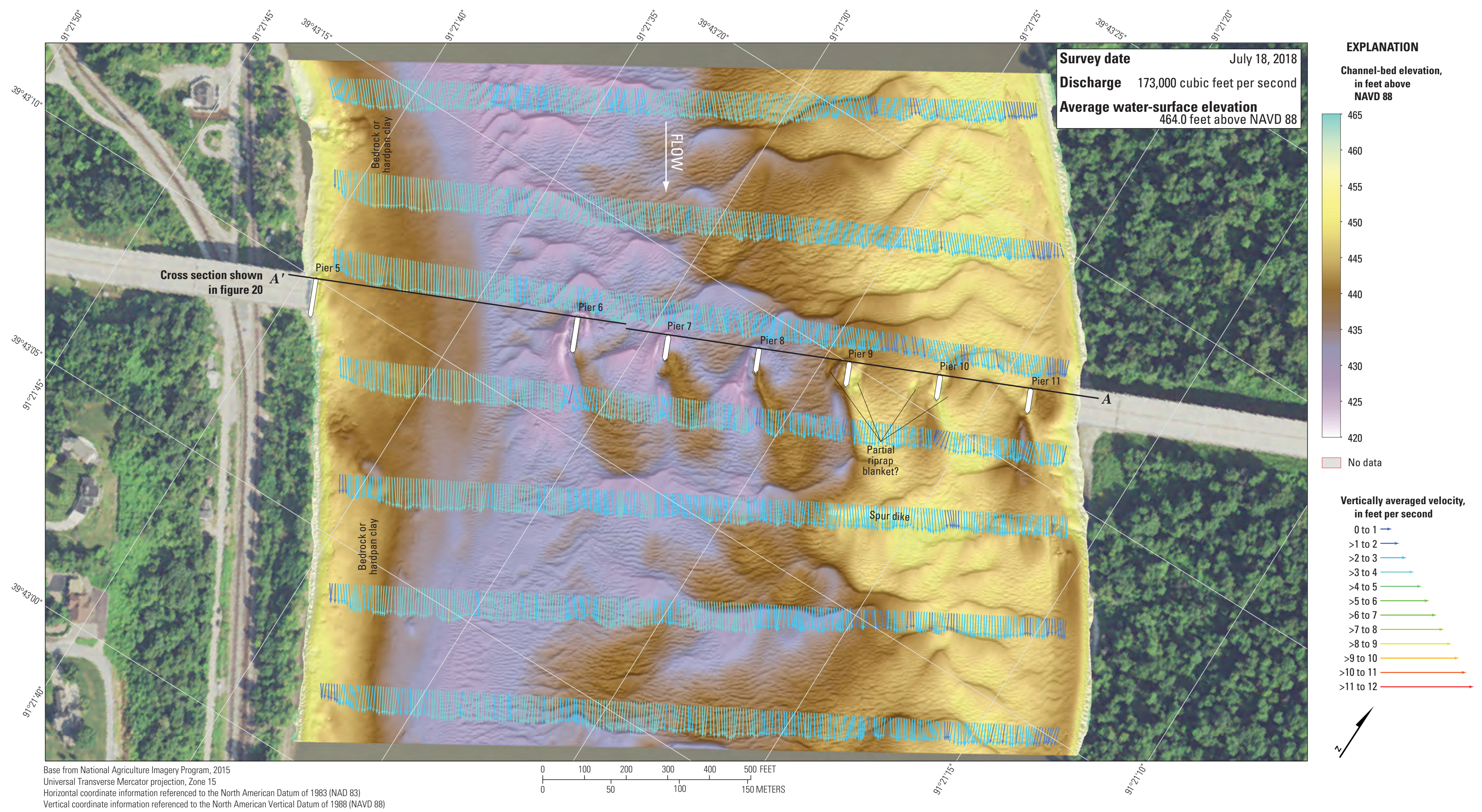

Figure 22. Bathymetry and vertically averaged velocities of the Mississippi River channel near structure A5054 on Interstate 72 at Hannibal, Missouri. 


\section{Structure L0135 on State Highway 51 at Chester, Illinois}

Structure L0135 (site 36) on State Highway 51 crosses the upper Mississippi River at RM 109.9 at Chester, Ill., southeast of and downstream from St. Louis, Mo. (fig. 1; table 2). The site was surveyed on July 24, 2018, and the average water-surface elevation of the river in the survey area, determined by the RTK GNSS tide solution, was $360.4 \mathrm{ft}$ (table 3). Streamflow on the Mississippi River was about 290,000 ft3/s during the survey (table 3).

The survey area was about 1,640 ft long and about $1,840 \mathrm{ft}$ wide, extending across the active channel from the left (northeast) bank to the right (southwest) bank in the main channel (fig. 23). The upstream end of the survey area was about $655 \mathrm{ft}$ upstream from the centerline of structure L0135, and piers 10 through 13 were in the water; however, pier 13 was in shallow water on the left bank. The channel-bed elevations ranged from about 317 to $346 \mathrm{ft}$ for most of the surveyed area (5 to 95 percentile range of the bathymetric data; table 3; fig. 24), except near pier 11 and in the thalweg along the left side of the channel (fig. 23). A series of small to medium dunes were present, both in the thalweg on the left (east) side of the channel, and on the right (west) side, with numerous smaller dunes and ripples present throughout the channel (fig. 23). A bedrock outcrop was present on the left (northeast) bank, and stone revetment was present on the right bank (fig. 23).

Near pier 11 (fig. 23), a substantial scour hole had a minimum channel-bed elevation of about $306 \mathrm{ft}$ (table 7), which is about $16 \mathrm{ft}$ below the average channel elevation upstream from the pier (figs. 23, 25, 1.5C, 1.5D). Information from bridge plans (Missouri Department of Transportation, written commun., 2000) indicates that pier 11 is founded on a caisson on bedrock, having about $40 \mathrm{ft}$ of bed material between the bottom of the scour hole and bedrock (fig. 25; table 7). Near pier 10 (fig. 23), a moderate scour hole had a minimum channelbed elevation of about $330 \mathrm{ft}$ (table 7), which is about $8 \mathrm{ft}$ below the average channel elevation upstream from the pier (figs. 23, 25, 1.5E, 1.5F). Pier 10 also is founded on a caisson on bedrock, having about $85 \mathrm{ft}$ of bed material between the bottom of the scour hole and bedrock (fig. 25; table 7). Pier 12 is founded on footings on the exposed bedrock on the right bank, with no apparent scour hole nearby (figs. 23, 25, $1.5 A, 1.5 B$; table 7 ). Pier 13 also is founded on footings on the exposed bedrock on the right bank, and was near the surveyed water surface with no apparent scour hole nearby (figs. 23, 25; table 7). In modern construction, bridge substructural elements usually are pinned or socketed to bedrock (American Association of State Highway Transportation Officials, 2012; Brown and others, 2010), but full exposure of usually buried substructural elements warrants special consideration and

\section{Structure L0135 on State Highway 51}


observation, even when designed to be exposed. The surveyed bed generally was lower than the original ground line from 1940 bridge plans (Missouri Department of Transportation, written commun., 2000) between piers 9 and 10 and between piers 11 and 13, and higher than the original ground line between piers 10 and 11 (fig. 25). The surveyed bed was approximately the same as the bed from the Level 2 scour survey in 2000 (Huizinga and Rydlund, 2004), except on the left bank (fig. 25); however, the ground line from the Level 2 bridge scour assessment was along the downstream side of the bridge and may have incorporated part of the downstream spur dike (fig. 23).

The difference between the survey on July 24, 2018, and the previous survey on June 9, 2014 (fig. 26), indicates minor overall deposition from 2014 to 2018, as indicated by an average difference of $+0.72 \mathrm{ft}$ between the bathymetric surfaces (table 8). The net volume of cut in the reach from 2014 to 2018 was about 57,200 $\mathrm{yd}^{3}$, and the net volume of fill was about 136,300 $\mathrm{yd}^{3}$, resulting in a net gain of about 79,100 $\mathrm{yd}^{3}$ of sediment. There was an area of scour near pier 11, and some localized scour of as much as $10 \mathrm{ft}$ in various locations throughout the middle of the channel; however, moderate deposition of as much as $10 \mathrm{ft}$ was present throughout the rest of the reach, including as much as $3 \mathrm{ft}$ of apparent deposition on the bedrock on the left (northeast) bank (fig. 26). The cross sections from these two surveys generally were similar to one another except between piers 10 and 11, and clearly show the apparent deposition on the left bank (fig. 25). The general shape of the frequency distribution of bed elevations was similar in 2014 and 2018, but the 2018 survey has a lower percentage of survey-grid cells from 335 to $340 \mathrm{ft}$ and a higher percentage from 340 to $344 \mathrm{ft}$ than 2014 (fig. 24). As with all difference maps in this report, substantial deposition or scour apparent at the faces of the piers results from minor horizontal positional variances between the surveys (see the "Uncertainty Estimation" section). Positional variances between the surveys may also account for the apparent deposition on the bedrock on the left (northeast) bank. The similarity of the shape of the left bank in the two cross sections (fig. 25) implies the apparent deposition may be the result of a localized vertical offset during the survey, rather than true deposition.

The vertically averaged velocity vectors indicate mostly uniform, expanding flow throughout most of the reach, ranging from about 2 to $9 \mathrm{ft} / \mathrm{s}$, with areas of shear along the right side of the channel (fig. 27). All the piers were aligned with flow, as indicated by little to no turbulence observed downstream that can be directly attributed to the piers (fig. 27). 


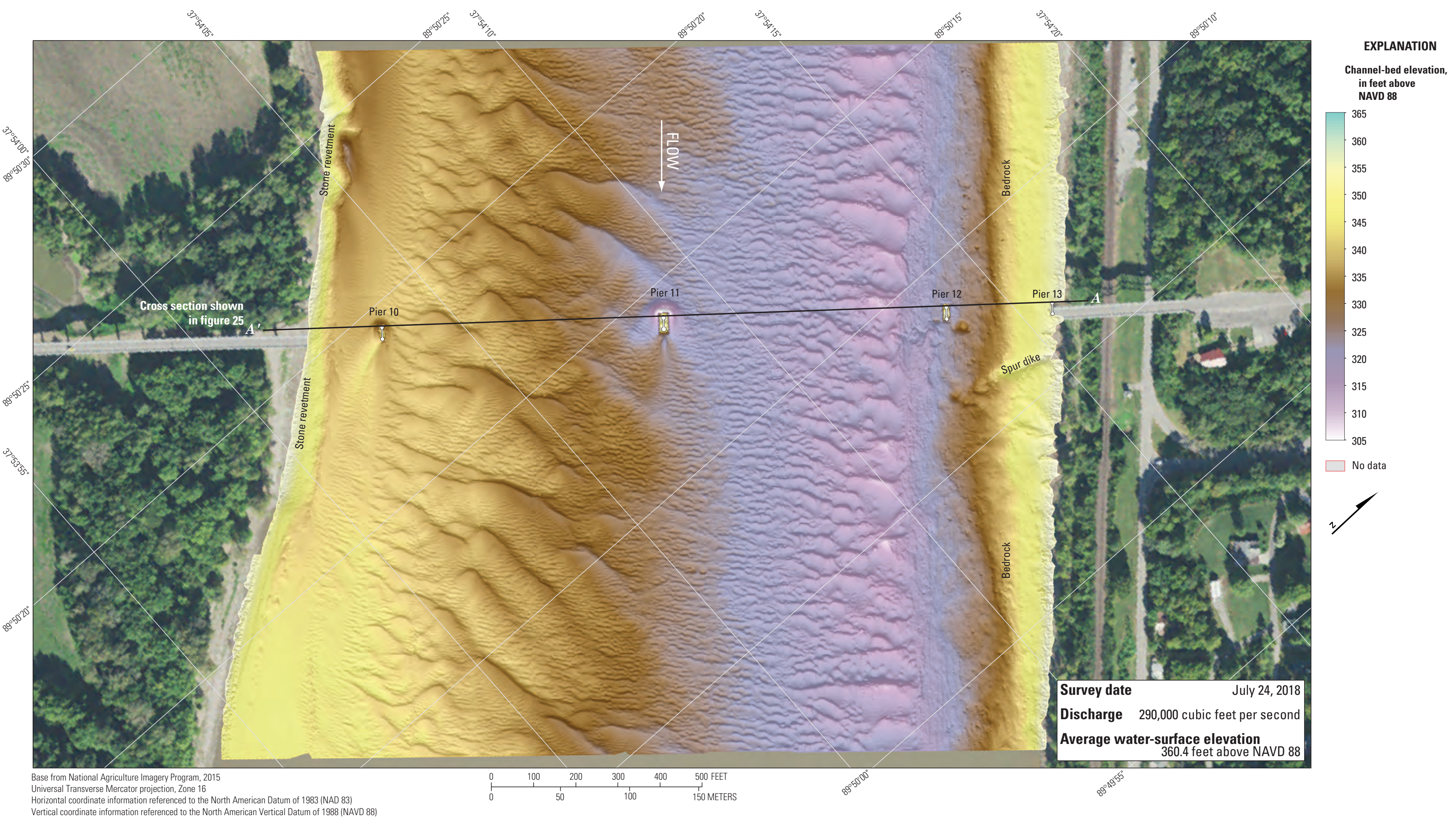

Figure 23. Bathymetric survey of the Mississippi River channel near structure L0135 on State Highway 51 at Chester, Illinois. 


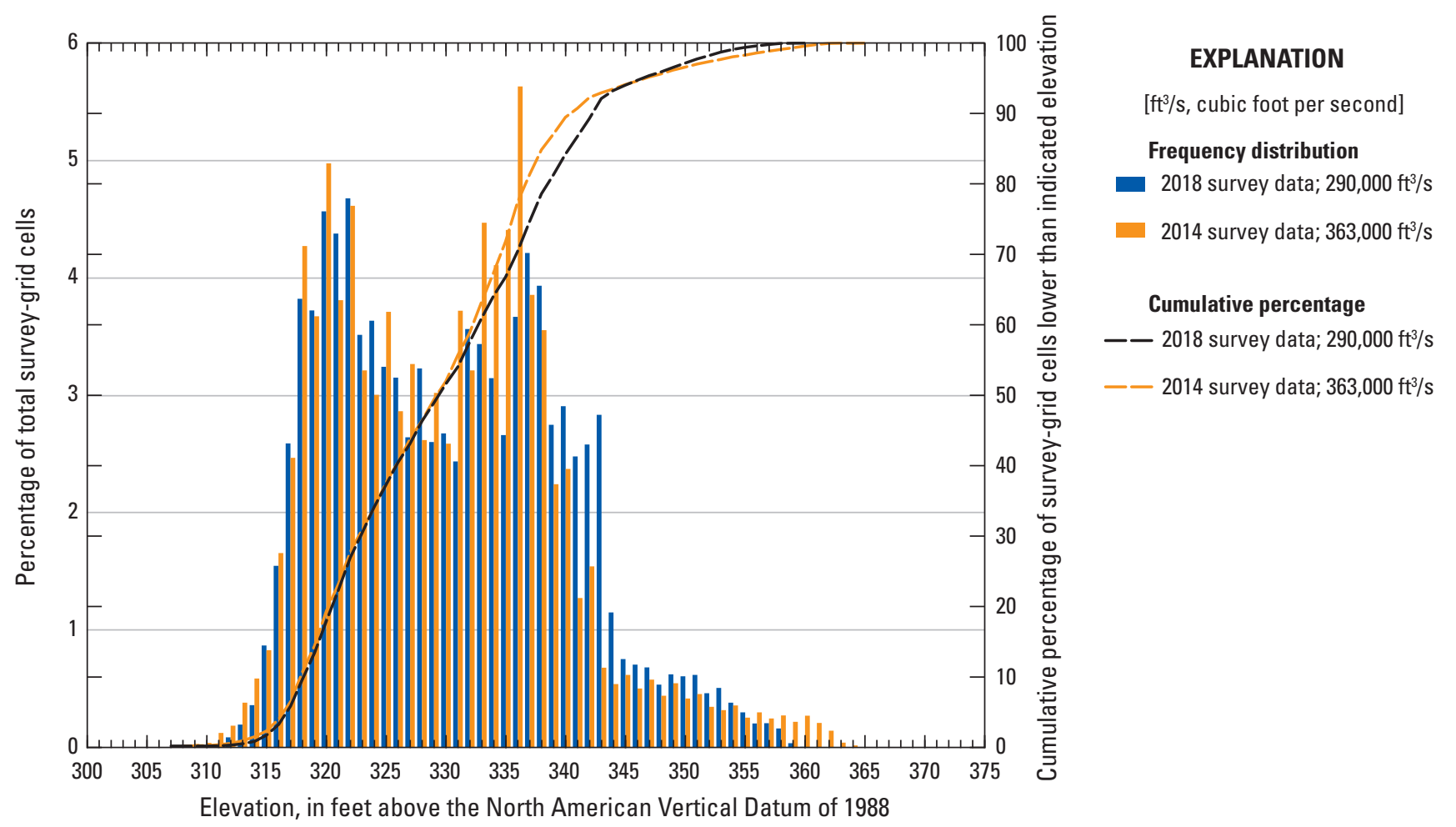

Figure 24. Frequency distribution of bed elevations for bathymetric survey-grid cells in 1-foot elevation bins on the Mississippi River near structure L0135 on State Highway 51 at Chester, Illinois, on July 24, 2018, compared to previous surveys (Huizinga, 2015). 


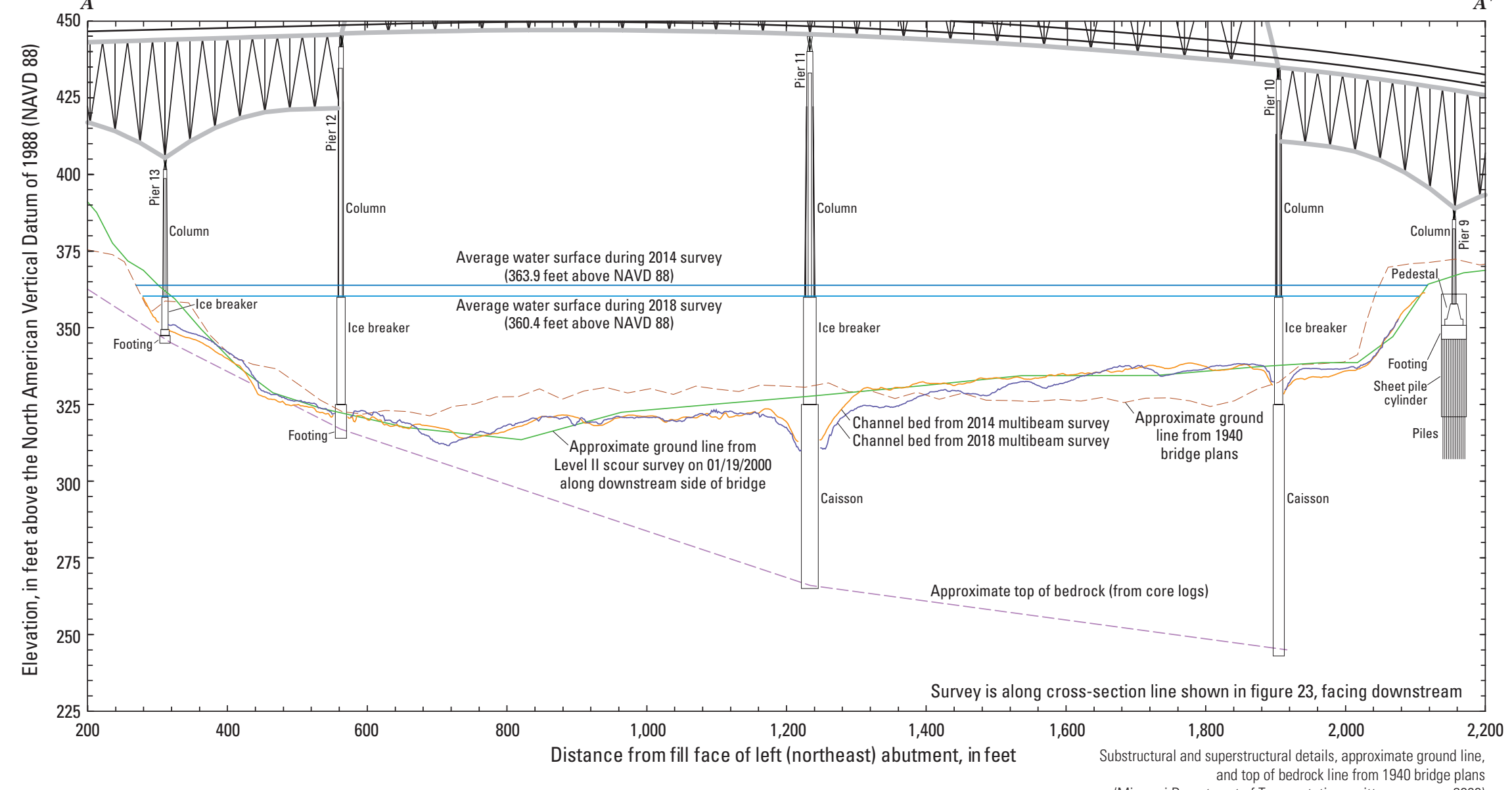

Part of bridge shown above (Missouri Depa

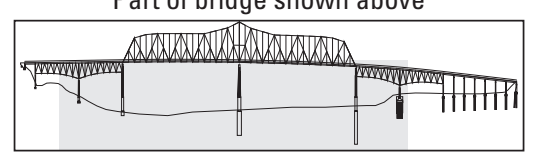

Figure 25. Key features, substructural and superstructural details, and surveyed channel bed of structure L0135 on State Highway 51 crossing the Mississippi River at Chester, Illinois. 


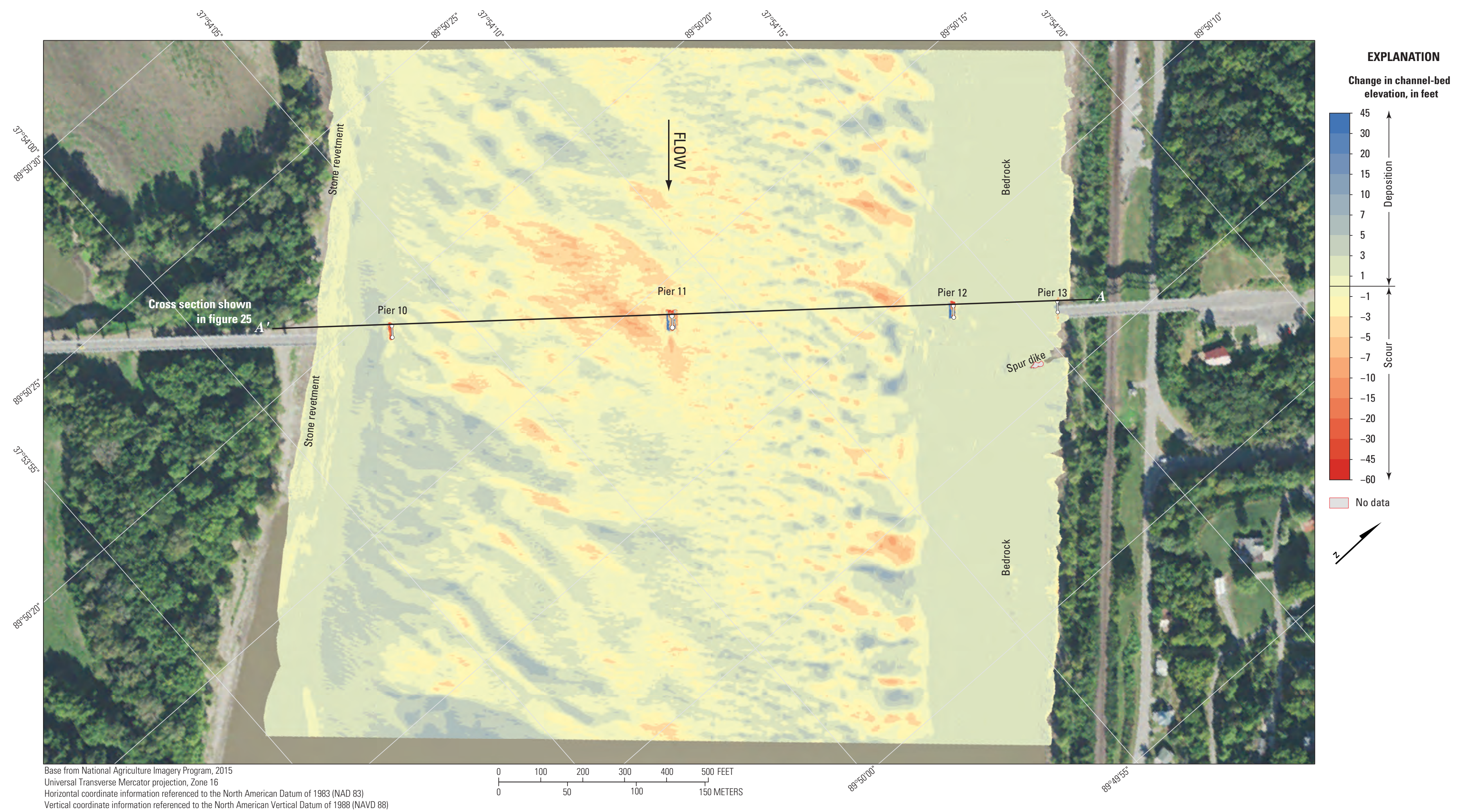

Figure 26. Difference between surfaces created from bathymetric surveys of the Mississippi River near structure L0135 on State Highway 51 at Chester, Illinois, on July 24, 2018, and June 9, 2014 


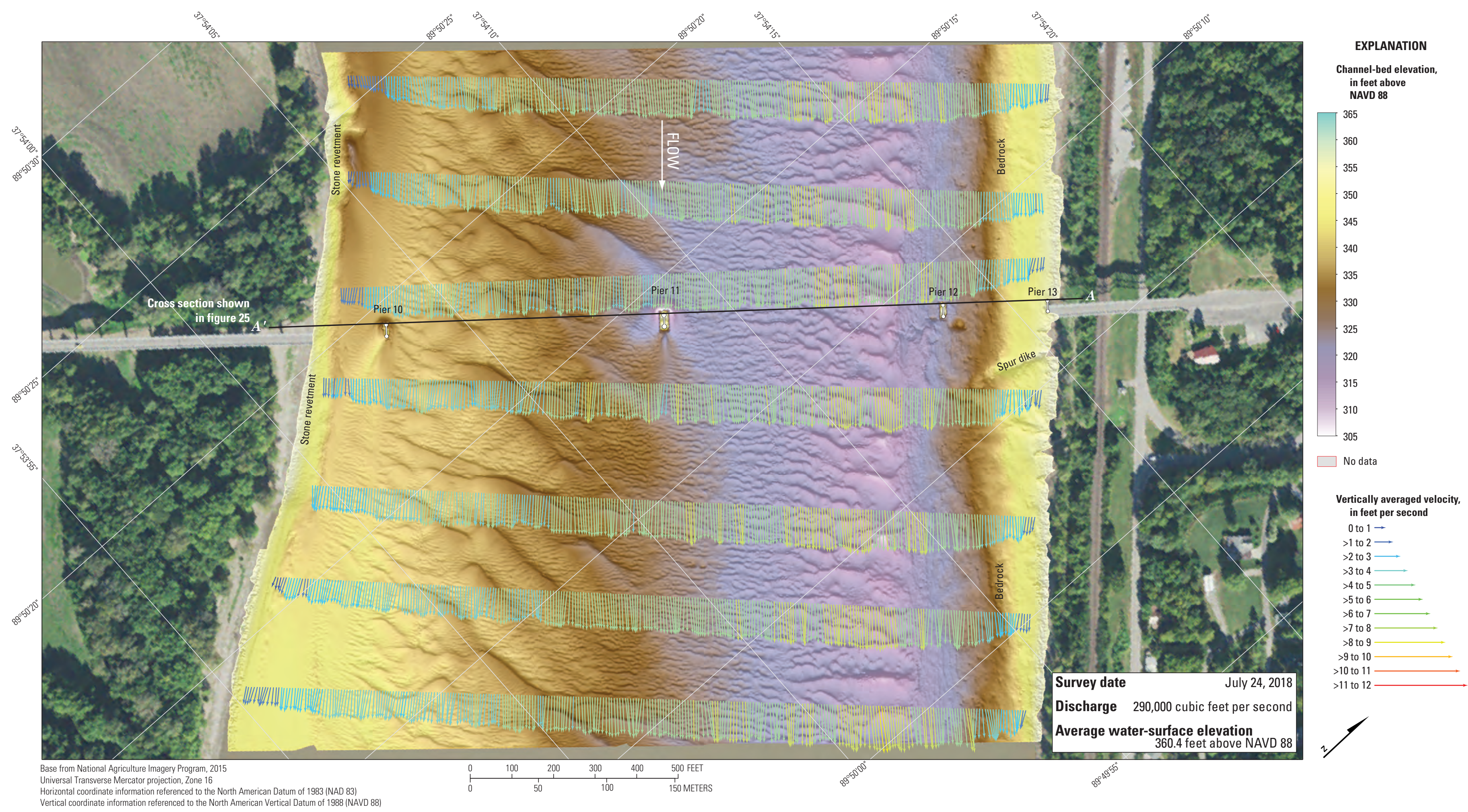

Figure 27. Bathymetry and vertically averaged velocities of the Mississippi River near structure L0135 on State Highway 51 at Chester, Illinois. 


\section{Structure A5076 on State Highway 34 at Cape Girardeau, Missouri}

Structure A5076 (site 37) on State Highway 34 crosses the upper Mississippi River at RM 51.5 at Cape Girardeau, Mo., southeast of and downstream from Chester, Ill., and St. Louis, Mo. (fig. 1; table 2). The site was surveyed on July 25, 2018, and the average water-surface elevation of the river in the survey area, determined by the RTK GNSS tide solution, was $328.2 \mathrm{ft}$ (table 3). Streamflow on the Mississippi River was about 282,000 ft3/s during the survey (table 3).

The survey area was about 1,640 ft long and about $1,970 \mathrm{ft}$ wide (perpendicular to flow), extending across the active channel from the left (east) bank to the right (west) bank in the main channel (fig. 28). The upstream end of the survey area was about $730 \mathrm{ft}$ upstream from the centerline of structure A5076 at pier 3, and piers 3 through 6 were in the water. Piers 2 and 7 were in very shallow water on the right and left banks, respectively, and were not surveyed. The channel-bed elevations ranged from about 278 to $314 \mathrm{ft}$ for most of the surveyed area (5 to 95 percentile range of the bathymetric data; table 3; fig. 29), except in the well-defined channel thalweg along the right bank, and downstream from piers 3 and 4 (fig. 28). Numerous small dunes and ripples were present throughout the channel. The area near the left bank upstream from the bridge was about 20 to $25 \mathrm{ft}$ shallower than on the right side of the channel (fig. 28).
Piers 3 and 4 seemed to be partially surrounded by piles of riprap or rock (figs. 28, 1.6E through $1.6 H$ ), with additional scour downstream from the piers reaching a minimum elevation of $270 \mathrm{ft}$ near pier 3 and 285 near pier 4 (fig. 28; table 7). Poorly defined, minor scour holes were observed near piers 5 and 6 (figs. 28, 1.6A through 1.6D), having a minimum channel-bed elevation of about $300 \mathrm{ft}$ at pier 5 and $311 \mathrm{ft}$ at pier 6 (table 7); however, the top of the footing was visible at pier 5 , and the top of the distribution cap was visible at piers 3 and 4 (figs. 28, 30). The minimum channel-bed elevation near pier 5 is about $15 \mathrm{ft}$ above the elevation of the bottom of the pier seal course of $285.00 \mathrm{ft}$, and the minimum channel-bed elevation near pier 6 is about $19 \mathrm{ft}$ above the elevation of the bottom of the pier seal course of $292.00 \mathrm{ft}$ (fig. 30; table 7). Information from bridge plans (Missouri Department of Transportation, written commun., 2014) indicates that piers 3 and 4 are founded on caissons on bedrock, having about $20 \mathrm{ft}$ of bed material between the bottom of the scour hole and bedrock at pier 3 , and $41 \mathrm{ft}$ of material at pier 4 . Piers 5 through 7 are founded on shafts drilled as much as $22 \mathrm{ft}$ into bedrock, having about $55 \mathrm{ft}$ of bed material between the bottom of the scour hole and bedrock at pier 5 , and about $66 \mathrm{ft}$ of material at pier 6 (fig. 30; table 7). The surveyed bed generally was similar to the previous survey in 2014, and the original ground line in 1996 from bridge plans, except near pier 4 (fig. 30).

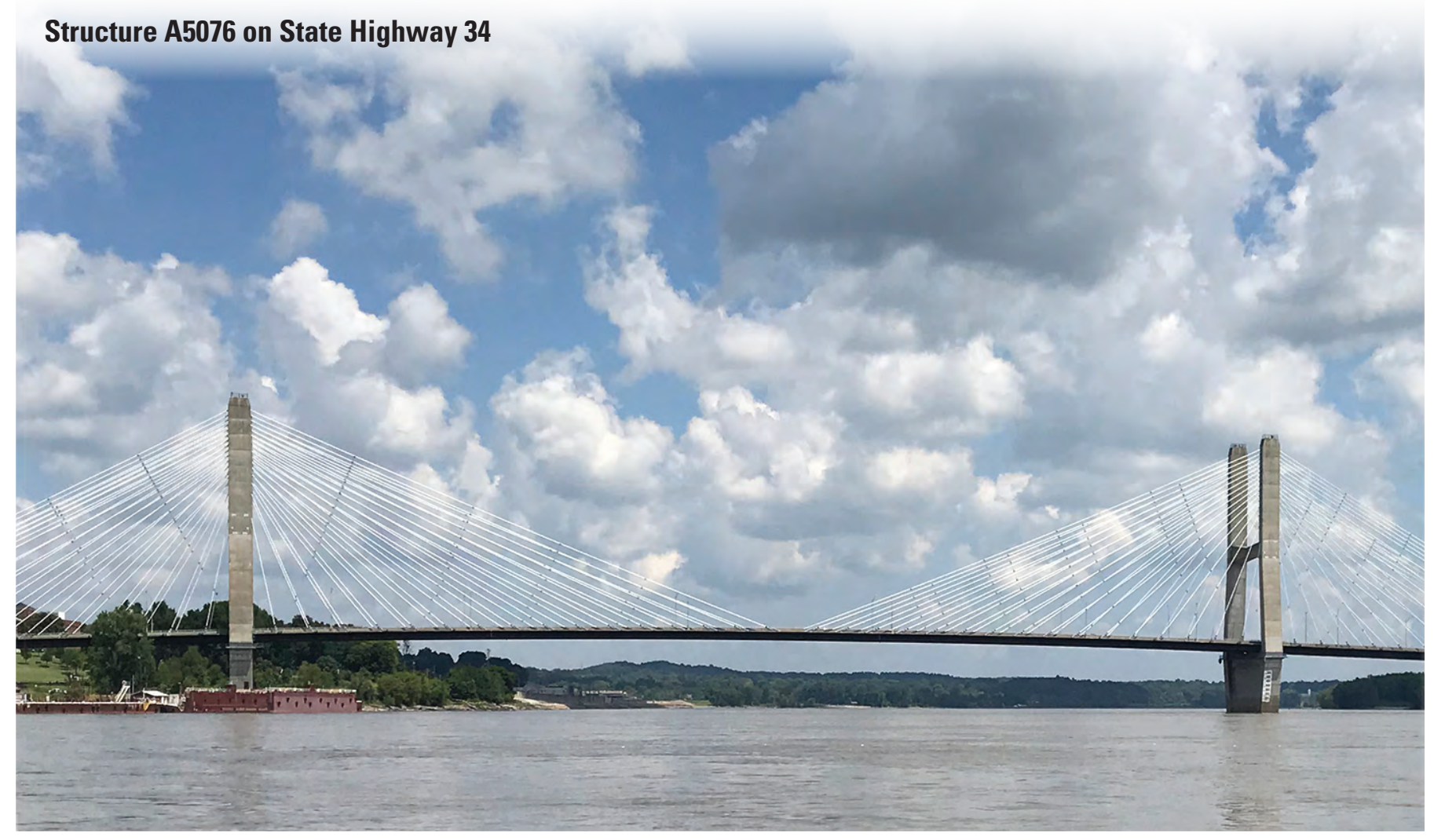


The difference between the survey on July 25, 2018, and the previous survey on June 10, 2014 (fig. 31), indicates a general balance between scour and deposition (an average difference of $+0.21 \mathrm{ft}$ between the bathymetric surfaces) throughout the reach from 2014 to 2018 (table 8). The net volume of cut in the reach from 2014 to 2018 was about 108,300 $\mathrm{yd}^{3}$, and the net volume of fill was about $132,400 \mathrm{yd}^{3}$, resulting in a net gain of about $24,100 \mathrm{yd}^{3}$ of sediment. Scour was observed in the upstream right and downstream middle of the channel, and downstream from the spur dike on the downstream left bank (fig. 31). Minor deposition was observed on the stone revetment on the upstream right side of the channel, and moderate deposition of as much as $7 \mathrm{ft}$ was observed along the toe of the right bank downstream, as well as along the left side of the channel both upstream and downstream (fig. 31). The frequency distribution of bed elevations in 2018 was of a similar shape to 2014, with a higher percentage of grid cells at elevations from 278 to $283 \mathrm{ft}$, and around $300 \mathrm{ft}$ (fig. 29).

The vertically averaged velocity vectors indicate mostly uniform flow throughout the thalweg of the channel along the right bank, ranging from about 5 to $9 \mathrm{ft} / \mathrm{s}$ with minor variations in velocity across the sections (fig. 32). Moderate non-uniform flow was observed along the left side of the channel, particularly downstream from the spur dike on the left bank. Piers 3 and 4 were skewed to approach flow, causing substantial wake vortices with flow reversal and well-defined deposition ridges downstream (figs. 28, 32) 


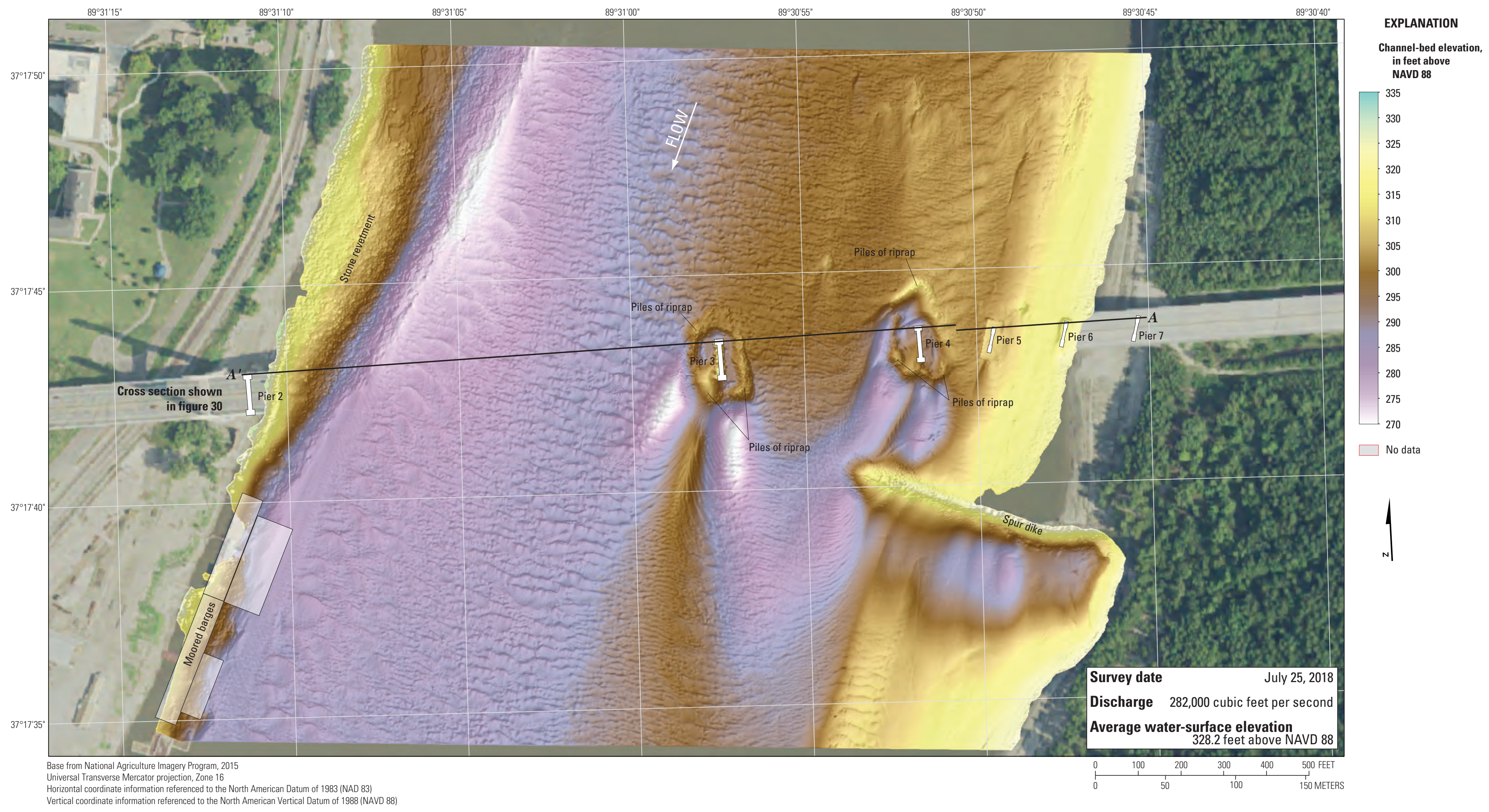

Figure 28. Bathymetric survey of the Mississippi River channel near structure A5076 on State Highway 34 at Cape Girardeau, Missouri. 


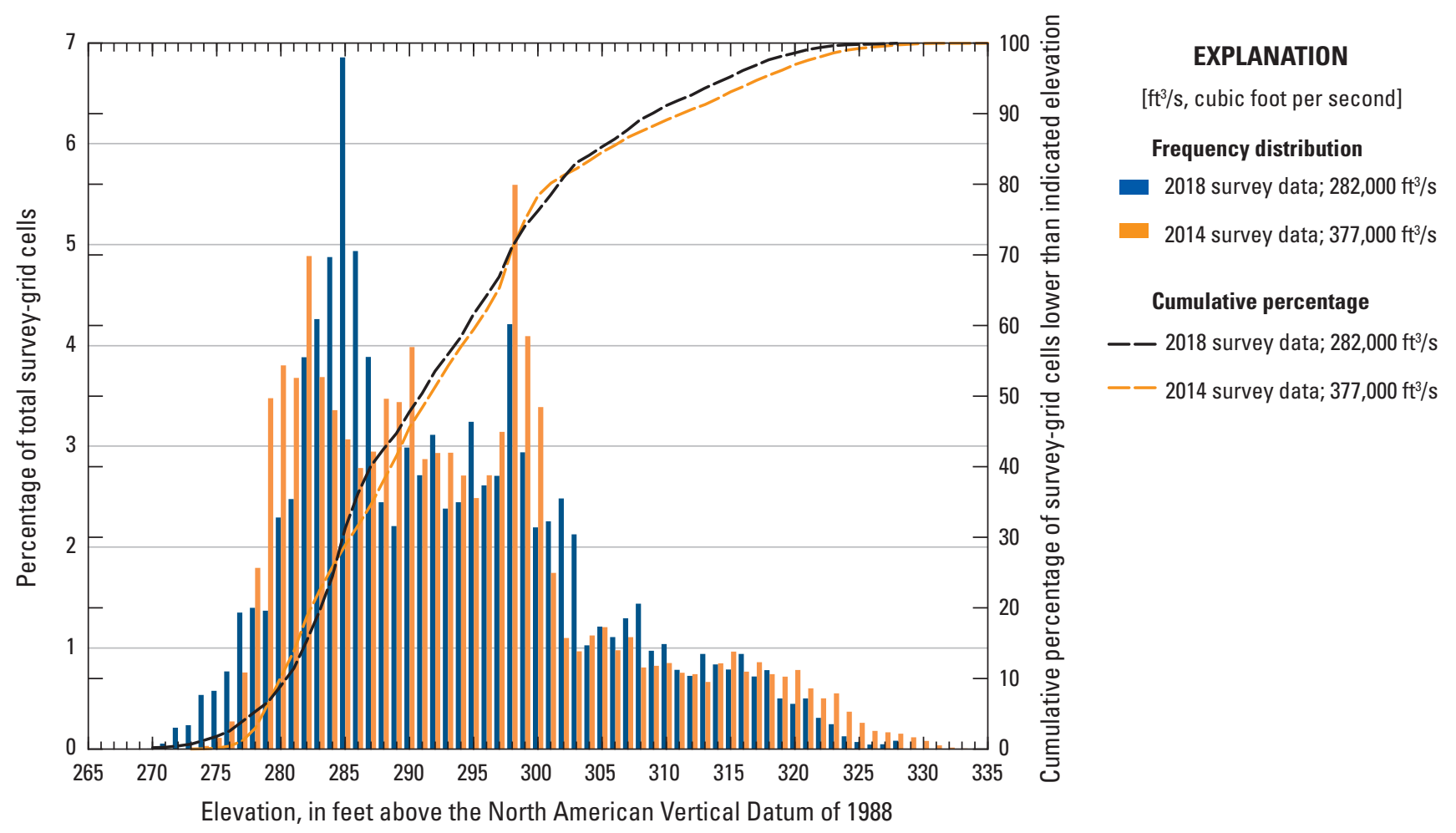

Figure 29. Frequency distribution of bed elevations for bathymetric survey-grid cells in 1-foot elevation bins on the Mississippi River near structure A5076 on State Highway 34 at Cape Girardeau, Missouri, on July 25, 2018, compared to previous surveys (Huizinga, 2015). 


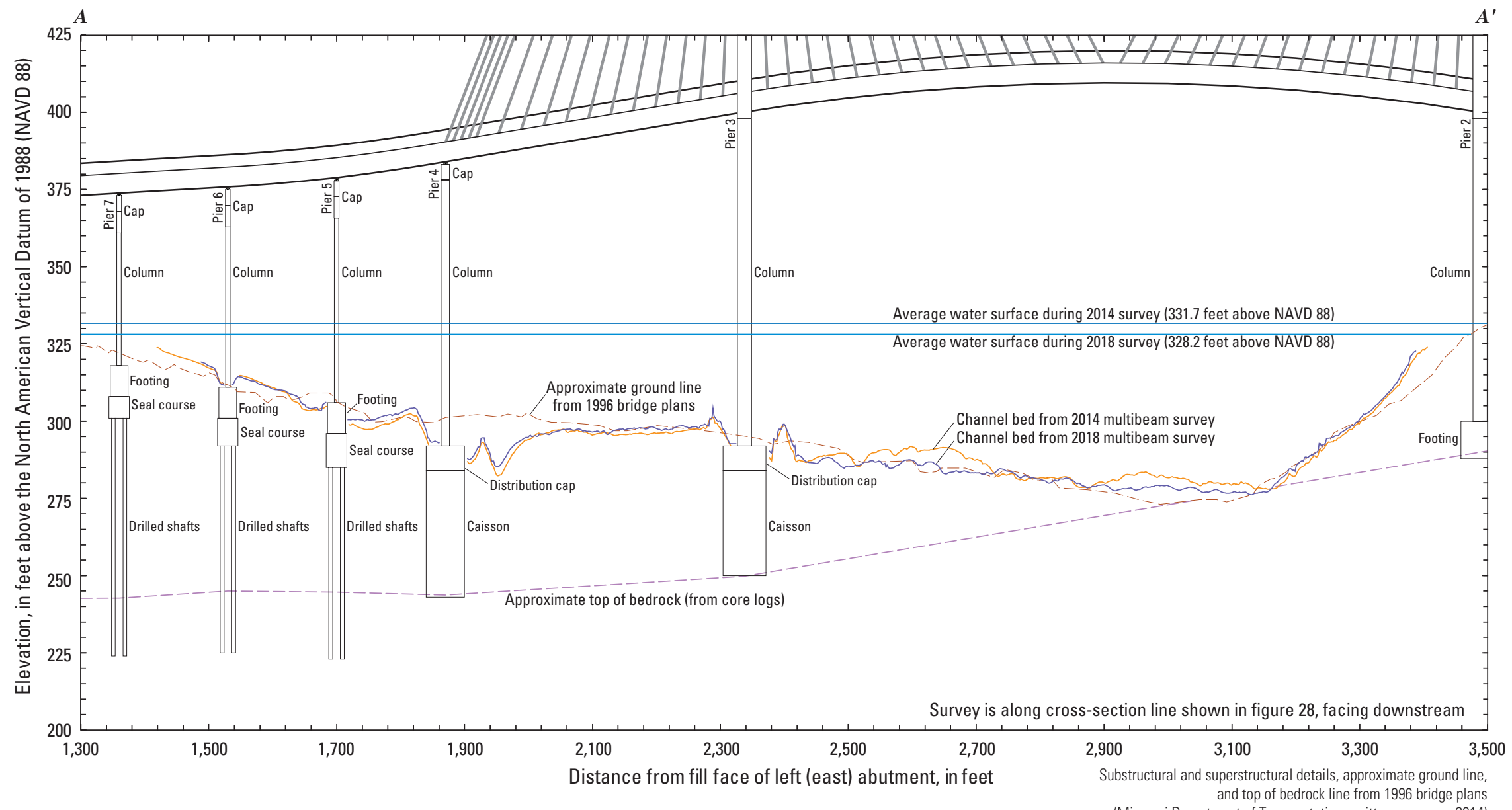

Part of bridge shown above (Missouri Depatr

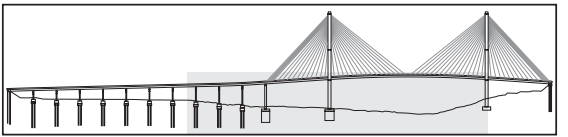

Figure 30. Key features, substructural and superstructural details, and surveyed channel bed of structure A5076 on State Highway 34 crossing the Mississippi River at Cape Girardeau, Missouri. 


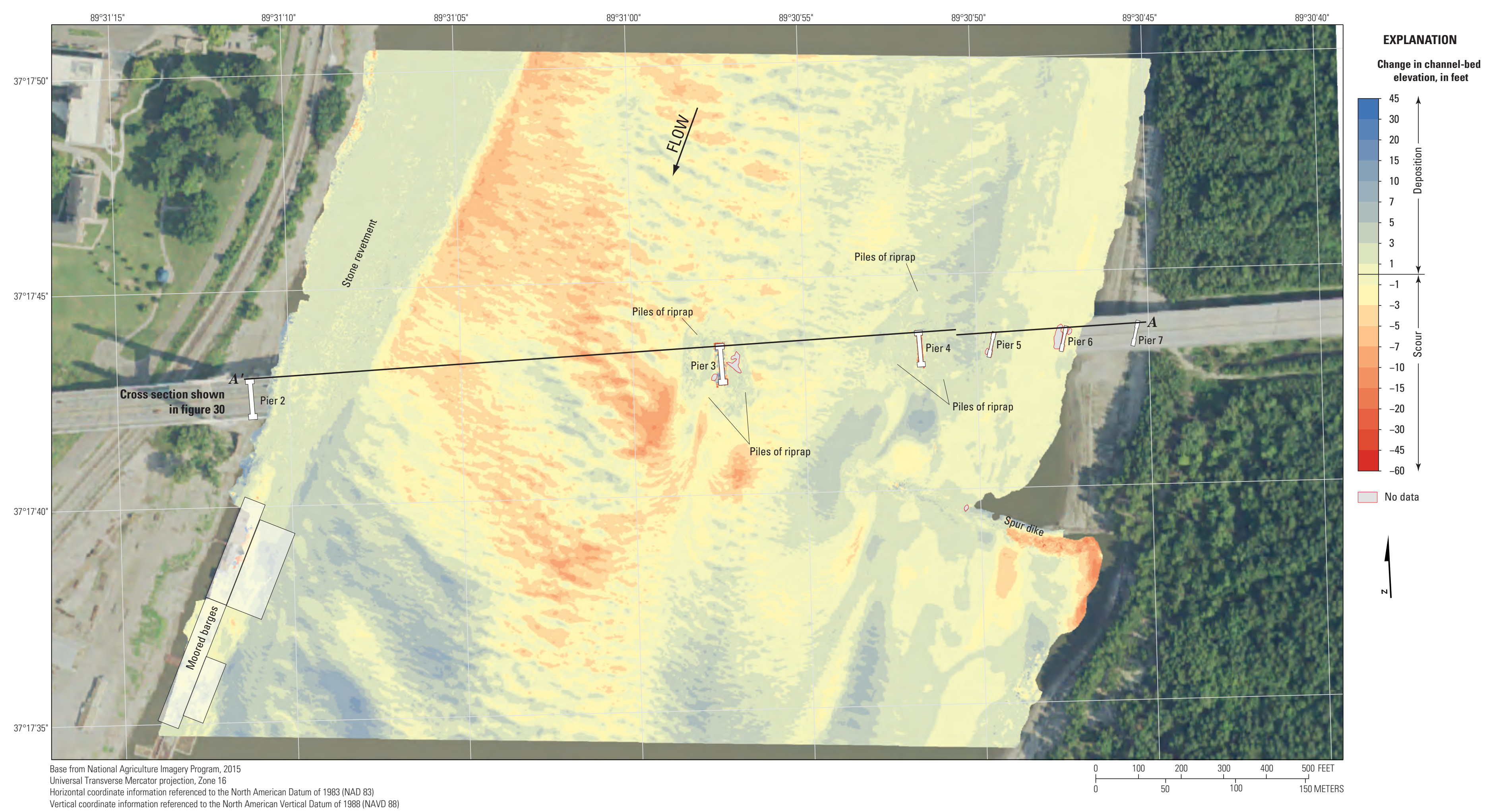

Figure 31. Difference between surfaces created from bathymetric surveys of the Mississippi River channel near structure A5076 on State Highway 34 at Cape Girardeau, Missouri, on July 25, 2018, and June 10, 2014. 


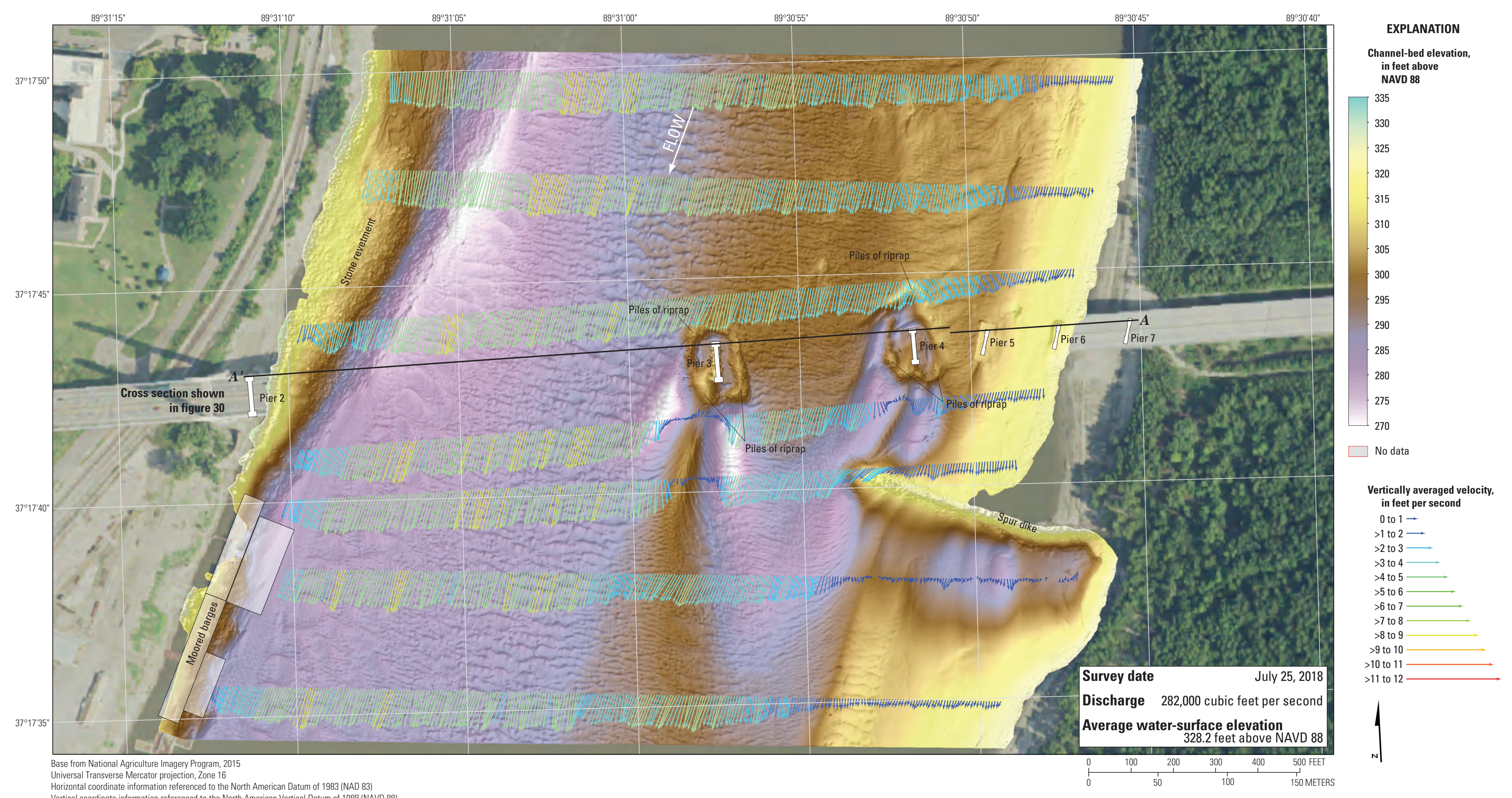

Figure 32. Bathymetry and vertically averaged velocities of the Mississippi River channel near structure A5076 on State Highway 34 at Cape Girardeau, Missouri. 


\section{Structure A1700 on Interstate 155 near Caruthersville, Missouri}

Structure A1700 (site 38) on Interstate 155 crosses the lower Mississippi River at RM 838.9 (of the lower Mississippi River) near Caruthersville, Mo., in the southeastern corner of Missouri (fig. 1; table 2). The site was surveyed on July 26, 2018, and the average water-surface elevation of the river in the survey area, determined by the RTK GNSS tide solution, was $245.9 \mathrm{ft}$ (table 3). Streamflow on the Mississippi River was about $420,000 \mathrm{ft} 3 / \mathrm{s}$ during the survey (table 3 ).

The survey area was about $1,640 \mathrm{ft}$ long and about $2,710 \mathrm{ft}$ wide, extending across the active channel from the left (southeast) bank to the right (northwest) bank in the main channel (fig. 33). The upstream end of the survey area was about $675 \mathrm{ft}$ upstream from the centerline of structure A1700, and bent 14 and piers 15 through 21 were in the water; however, bent 14 and pier 21 were in shallow water on the right and left banks, respectively, and bent 14 was not surveyed. The channel-bed elevations ranged from about 178 to $220 \mathrm{ft}$ for most of the surveyed area (5 to 95 percentile range of the bathymetric data; table 3; fig. 34), except in areas of local scour on the right bank near the bridge and on the left bank near the downstream end of the reach (table 3; fig. 33). A few medium to large dunes were observed in the channel downstream from the bridge, as well as numerous small dunes and ripples throughout the channel (fig. 33).
Near pier 20, a small to moderate scour hole had a minimum channel-bed elevation of about $190 \mathrm{ft}$ (table 7), which is about $8 \mathrm{ft}$ below the average channel elevation upstream from the pier (fig. 35; table 7). Near pier 17, a small scour hole had a minimum channel-bed elevation of about $205 \mathrm{ft}$ (table 7), which is about $9 \mathrm{ft}$ below the average channel elevation upstream from the pier (fig. 35; table 7). Although a discernable scour hole was not observed near pier 16 (fig. 33), the minimum channel-bed elevation near that pier was about $196 \mathrm{ft}$, which is about $0.5 \mathrm{ft}$ below the bottom of the seal course elevation for that pier (fig. 35; table 7). Information from bridge plans (Missouri Department of Transportation, written commun., 2007) indicates that bent 14 and piers 15 to 18 are founded on piles, and piers 19 to 21 are founded on caissons, all with an unknown depth to bedrock (fig. 35; table 7); however, piers 18, 19, and 20 each are surrounded by a riprap blanket that seems to mitigate scour to some extent (fig. 35). These riprap blankets were installed at the time of bridge construction in 1973 (Missouri Department of Transportation, written commun., 2007), and were observed during the 2018 survey (figs. 1.7A through 1.7F). An object observed near pier 20 in the 2018 survey (fig. 1.7A) as well as in previous surveys, and identified in previous surveys as a sunken barge (see fig. 30 in Huizinga, 2015), likely is part of the cribbing placed around the riprap scour countermeasures during construction (Missouri Department of Transportation, written commun., 2007) that has shifted and projects upward

\section{Structure A1700 on Interstate 155}

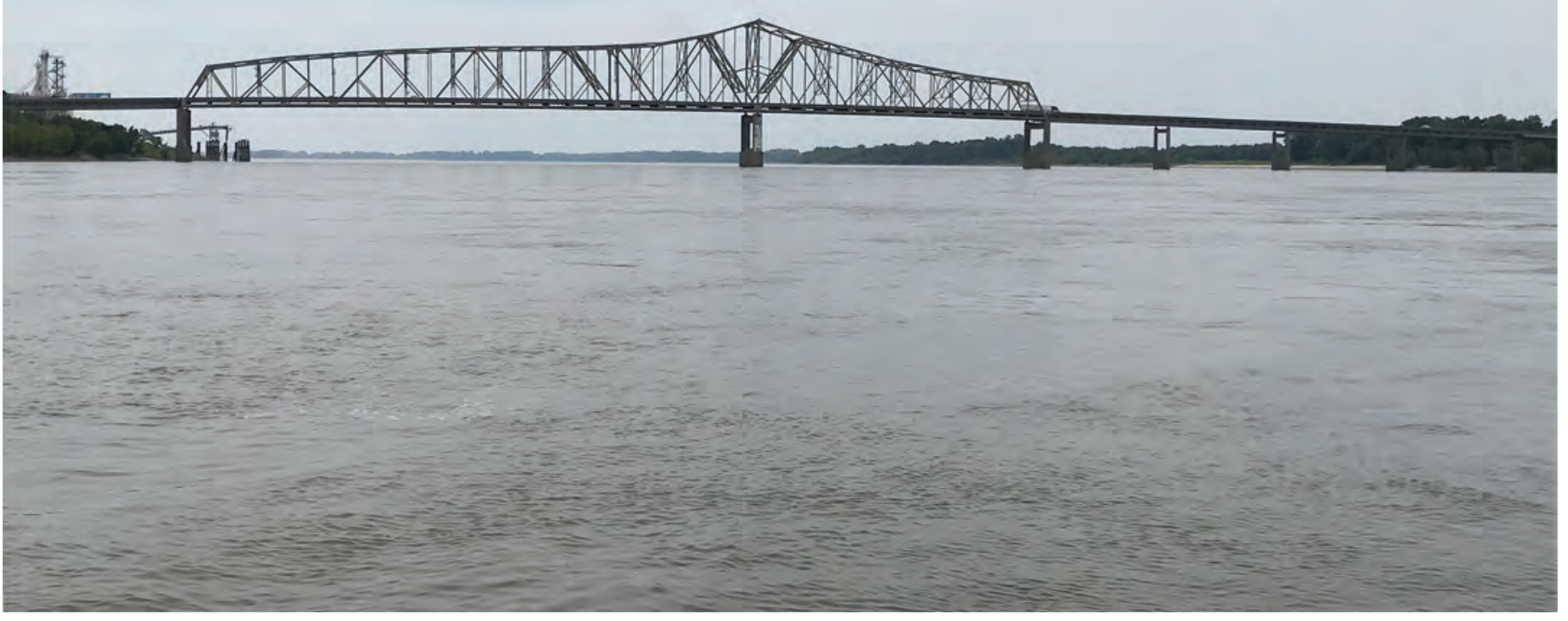


into flow. The cross section along the upstream bridge face (fig. 35) shows a localized high bed elevation near the left edge of the riprap blanket at pier 20 that coincides with the observed object. Pier 15 is embedded in the stone revetment along the right bank (figs. 33, 35, 1.8E, 1.8F), and pier 16 seems to be surrounded by several almost random piles of riprap, which may help mitigate scour (figs. 33, 35, 1.8C, 1.8D).

The surveyed bed generally varies substantially between surveys on the left side of the channel (from the left bank to pier 19), and varied moderately on the right side (from pier 19 to the right bank; fig. 35). The 2008 survey was during relatively low-flow conditions on the Mississippi River, and the cross section along the upstream side of the bridge generally was the highest of all the surveys in the left side of the channel; however, on the right side of the channel, the 2008 surveyed bed generally was the lowest (fig. 35). Conversely, the 2011 survey was during extreme flood conditions, and the cross section was the lowest in the left side of the channel, and the highest in the right side (fig. 35). At the deepest point in the cross section, the 2011 surveyed bed was $161 \mathrm{ft}$, which is $24 \mathrm{ft}$ below the lowest elevation of $185 \mathrm{ft}$ from both the 2008 survey and 2014 survey, and $13 \mathrm{ft}$ below the lowest elevation of $174 \mathrm{ft}$ from the 2018 survey. The riprap blanket around pier 20 is evident in the 2018 survey (fig. 33), and the cross sections from the surveys in 2011, 2014, and 2018 indicate the riprap blanket has seemed to slump around the nose of the pier (fig. 35). Whether this slumped blanket near the pier is the result of how the riprap was dumped around the pier, or the result of armoring of subsequent scour activity, is unknown; however, it has not changed substantially in the recent surveys.

The difference between the survey on July 26, 2018, and the previous nonflood survey on June 11, 2014 (fig. 36), indicates more scour than deposition throughout the reach from 2014 to 2018 , resulting in an average difference of $-3.37 \mathrm{ft}$ between the bathymetric surfaces (table 8 ). The net volume of cut in the reach from 2014 to 2018 was about 800,000 $\mathrm{yd}^{3}$, and the net volume of fill was about $265,000 \mathrm{yd}^{3}$, resulting in a net loss of about 535,000 $\mathrm{yd}^{3}$ of sediment. Moderate to substantial scour of as much as $30 \mathrm{ft}$ in the thalweg on the left (south) side is balanced with localized deposition of as much as $20 \mathrm{ft}$ on the right (north) side of the channel, but the area of scour is more wide-spread than the deposition (fig. 36). A pile of rocks present upstream from the bridge near the right (north) bank in 2014 (see fig. 26 in Huizinga, 2015) was removed sometime after the 2014 survey, resulting in additional localized apparent scour there (fig. 36). Localized deposition along the toe of the left (south) bank upstream from the bridge implies additional stone revetment may have been placed there (fig. 36). The frequency distribution for 2018 has a higher percentage of grid cells between 176 and $190 \mathrm{ft}$ than 2014, and a lower percentage between 194 and $204 \mathrm{ft}$ (fig. 34). The cumulative percentage curve is between the 2011 and 2014/2008 curves below about $200 \mathrm{ft}$ elevation (fig. 34).

The difference between the survey on July 26, 2018, and the flood survey on May 5, 2011 (fig. 37), indicates substantial deposition of as much as $30 \mathrm{ft}$ in the thalweg along the left (south) side of the channel from 2011 to 2018, resulting in an average difference of $+5.83 \mathrm{ft}$ between the bathymetric surfaces (table 8). The net volume of cut in the reach from 2011 to 2018 was about $121,000 \mathrm{yd}^{3}$, and the net volume of fill was about $965,000 \mathrm{yd}^{3}$, resulting in a net gain of about 844,000 $\mathrm{yd}^{3}$ of sediment. Very localized scour of as much as $20 \mathrm{ft}$ occurred downstream from the protruding rock revetment on the right (north) bank at the bridge (fig. 37). The frequency distribution for 2018 has a higher percentage of grid cells between 176 and $190 \mathrm{ft}$ than 2011, but the 2011 distribution extended substantially lower than 2018 (fig. 34). The frequency distributions and cumulative percentages for 2011 and 2018 are similar above $212 \mathrm{ft}$ (fig. 34).

The difference between the survey on July 26, 2018, and the earliest survey on December 10, 2008 (fig. 38), indicates more scour than deposition throughout the reach from 2008 to 2018 , resulting in an average difference of $-3.98 \mathrm{ft}$ between the bathymetric surfaces (table 8). The net volume of cut in the reach from 2008 to 2018 was about 766,000 $\mathrm{yd}^{3}$, and the net volume of fill was about $255,000 \mathrm{yd}^{3}$, resulting in a net loss of about 511,000 $\mathrm{yd}^{3}$ of sediment. Moderate to substantial scour of as much as $30 \mathrm{ft}$ in the thalweg on the left (south) side is balanced with localized deposition of as much as $20 \mathrm{ft}$ on the right (north) side of the channel, but the area of scour is more widespread than the deposition (fig. 38). The frequency distribution for 2008 is similar to 2014, but does not extend as high up the banks because of the more limited surveyed area (fig. 34; table 8).

The vertically averaged velocity vectors for the 2018 survey indicate mostly uniform flow throughout a majority of the reach, with small areas of flow disturbance and shear flow, particularly along the banks near the constrictions at the bridge and downstream (fig. 39). Velocities ranged from about 5 to $9 \mathrm{ft} / \mathrm{s}$ for the left (south) side of the channel, and from 1 to $5 \mathrm{ft} / \mathrm{s}$ for the right (north) side of the channel, and low velocities and flow reversals were observed downstream from the bank constrictions at the bridge. The piers generally were aligned with flow, with minimal wake vortices observed downstream (fig. 39).

\section{General Findings and Implications}

Several of the findings at each surveyed bridge were common to all the bridges, and some findings were evident only when results of the surveys were examined as a set. These general findings are of benefit in the assessment of scour at the surveyed bridges, as well as other bridges close by or in similar settings.

\section{Effects of Moderate Flooding Compared to Previous Surveys}

Richardson and Davis (2001) separate long-term aggradation and degradation of a channel from the contraction and local scour that happens at a bridge site during floods. 


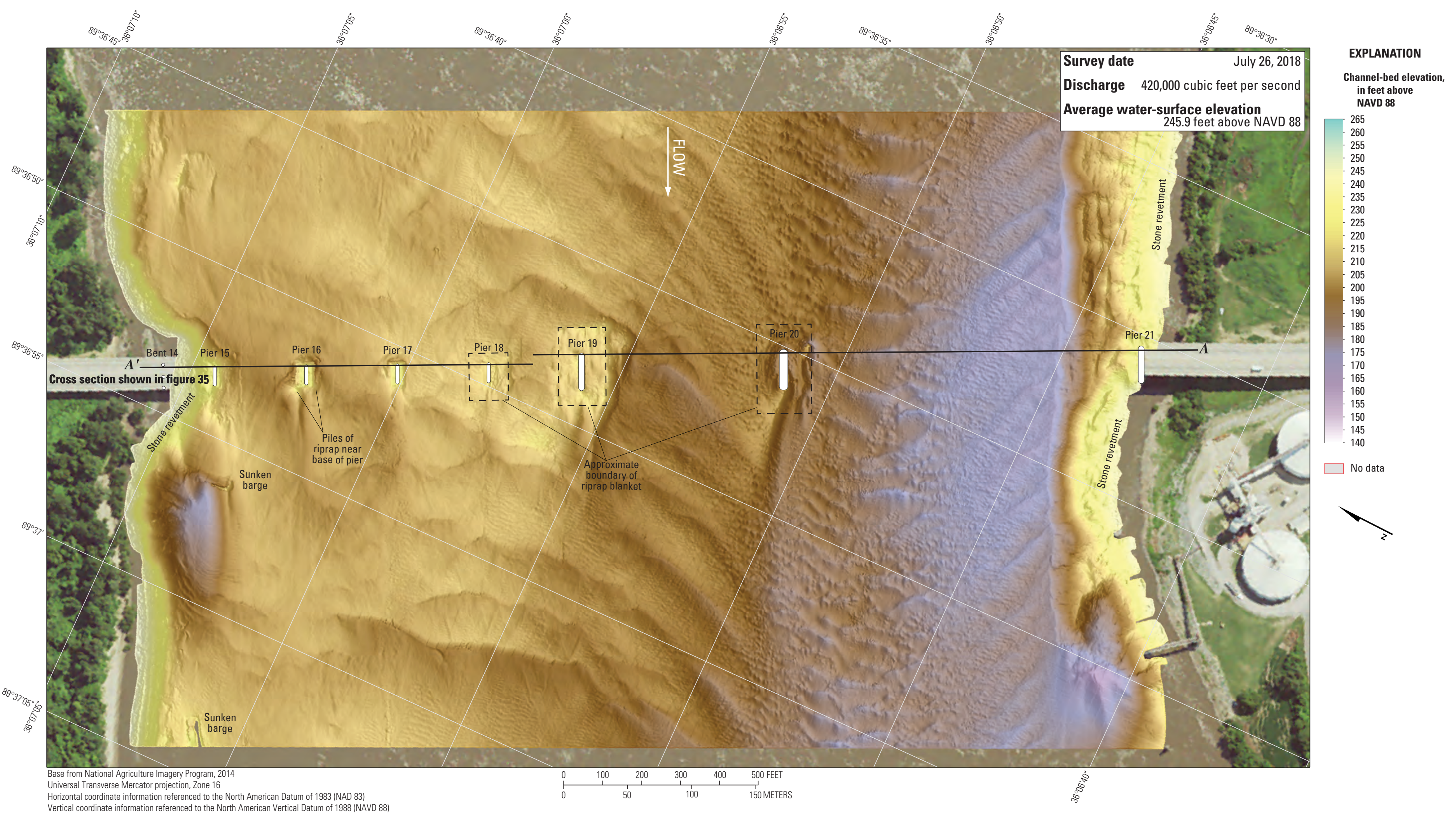

Figure 33. Bathymetric survey of the Mississippi River channel near structure A1700 on Interstate 155 near Caruthersville, Missouri. 

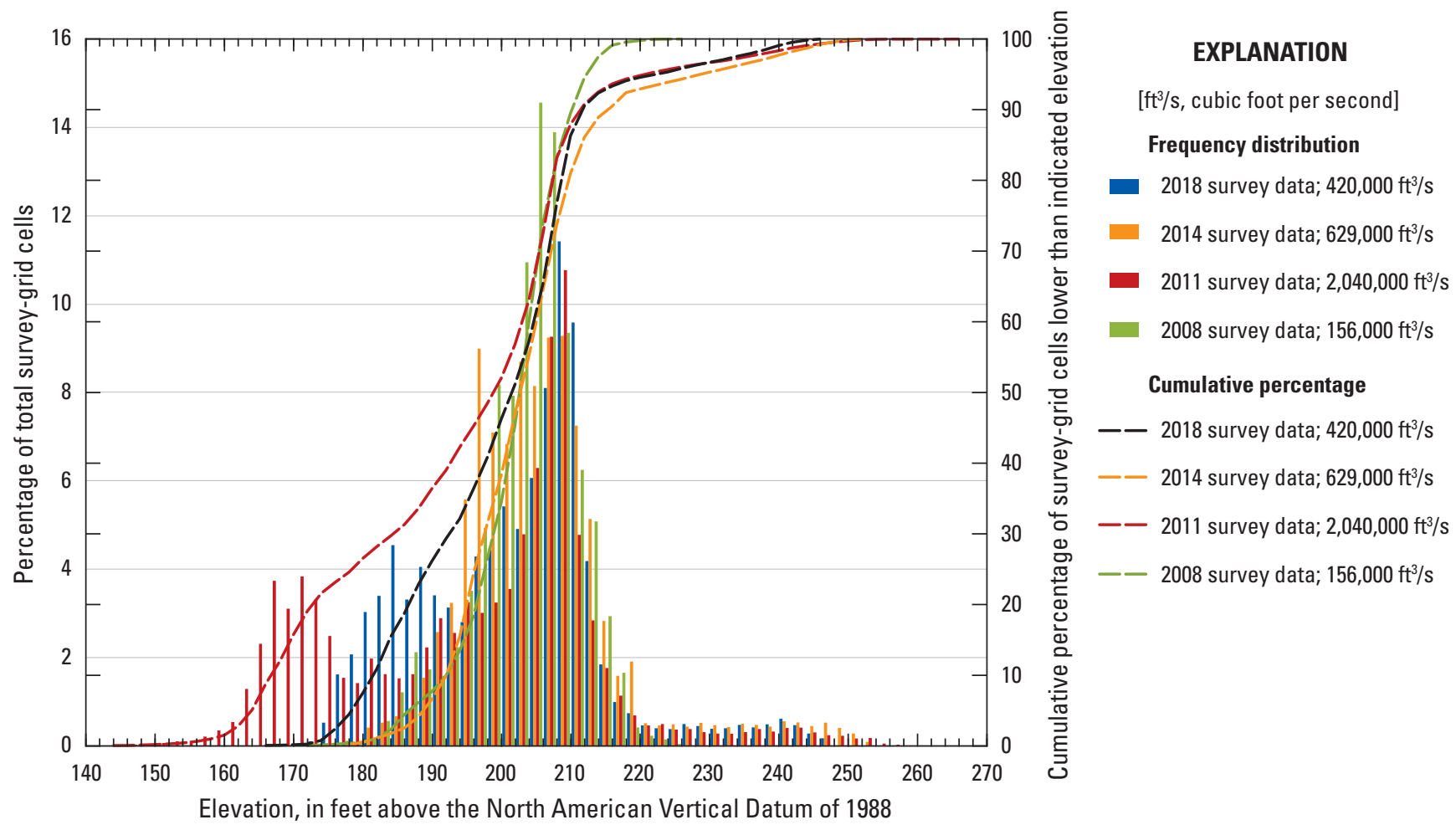

Figure 34. Frequency distribution of bed elevations for bathymetric survey-grid cells in 1-foot elevation bins on the Mississippi River near structure A1700 on Interstate 155 near Caruthersville, Missouri, on July 26, 2018, compared to previous surveys (Huizinga, 2015).

Contraction scour is the general change in the channel-bed elevation across a bridge opening resulting from the passage of a flood through a constriction, where more material is in suspension and transport. Local scour is the localized erosion of material caused by flow-vortex action that forms near bridge piers and abutments. Although all the scour processes (long term, contraction, and local scour) continually are at work, contraction and local scour generally are cyclic for the live-bed scour typically observed in alluvial channels and generally result in a decrease and subsequent increase of the channel-bed elevation during and after a flood.

The configuration and size of bed forms observed during the current (2018) surveys on the periphery of Missouri are dependent on more than the instantaneous streamflow at a given site. There are several factors and interactions of factors that affect sediment transport conditions and the resultant bed configuration. Although it is beyond the scope of the current (2018) study to examine all of the antecedent conditions that created the observed channel-bed configuration, the following discussion attempts to draw conclusions based on the conditions observed at each site during the current (2018) and previous surveys.

As discussed in the previous report about the periphery of Missouri sites (Huizinga, 2015), the dynamics of flooding can be slightly different between the Missouri and Mississippi Rivers. Most large flood durations on both rivers can be measured in weeks and months because of the large upstream contributing drainage area; however, the presence of locks and dams on the upper Mississippi River upstream from St. Louis can lessen the magnitude and lengthen the duration of a given flood wave, particularly upstream from St. Louis. Downstream from St. Louis, the increase in drainage area from the Missouri River can increase the magnitude and lengthen the duration of a given flood wave if flood conditions on the Missouri River combine with flood conditions on the Mississippi River, or a flood wave on one river may be entirely mitigated if the other river is not in flood. A similar phenomenon exists on the lower Mississippi River downstream from Cairo, Ill., based on the flow conditions on the Ohio River. As described in the "Description of Flow Conditions" section earlier in this report, all the surveys in the current (2018) study were on the recession limb of a longer-duration flood pulse (fig. 2). However, the peak of the flood at the downstream-most site of Caruthersville (site 38) occurred earliest in time, before the upstream-most site on the Missouri at Brownville (site 1; fig. 2), which means higher flow in the Ohio River Basin likely contributed to the flood wave observed at Caruthersville.

Streamflows at the Missouri River sites during the 2018 surveys ranged from about 1.5 to 2.0 times greater than the 2014 streamflows, and average water-surface elevations were 6.0 to $7.9 \mathrm{ft}$ higher in 2018 than in 2014 (table 8). However, the average differences between the 2018 and 2014 


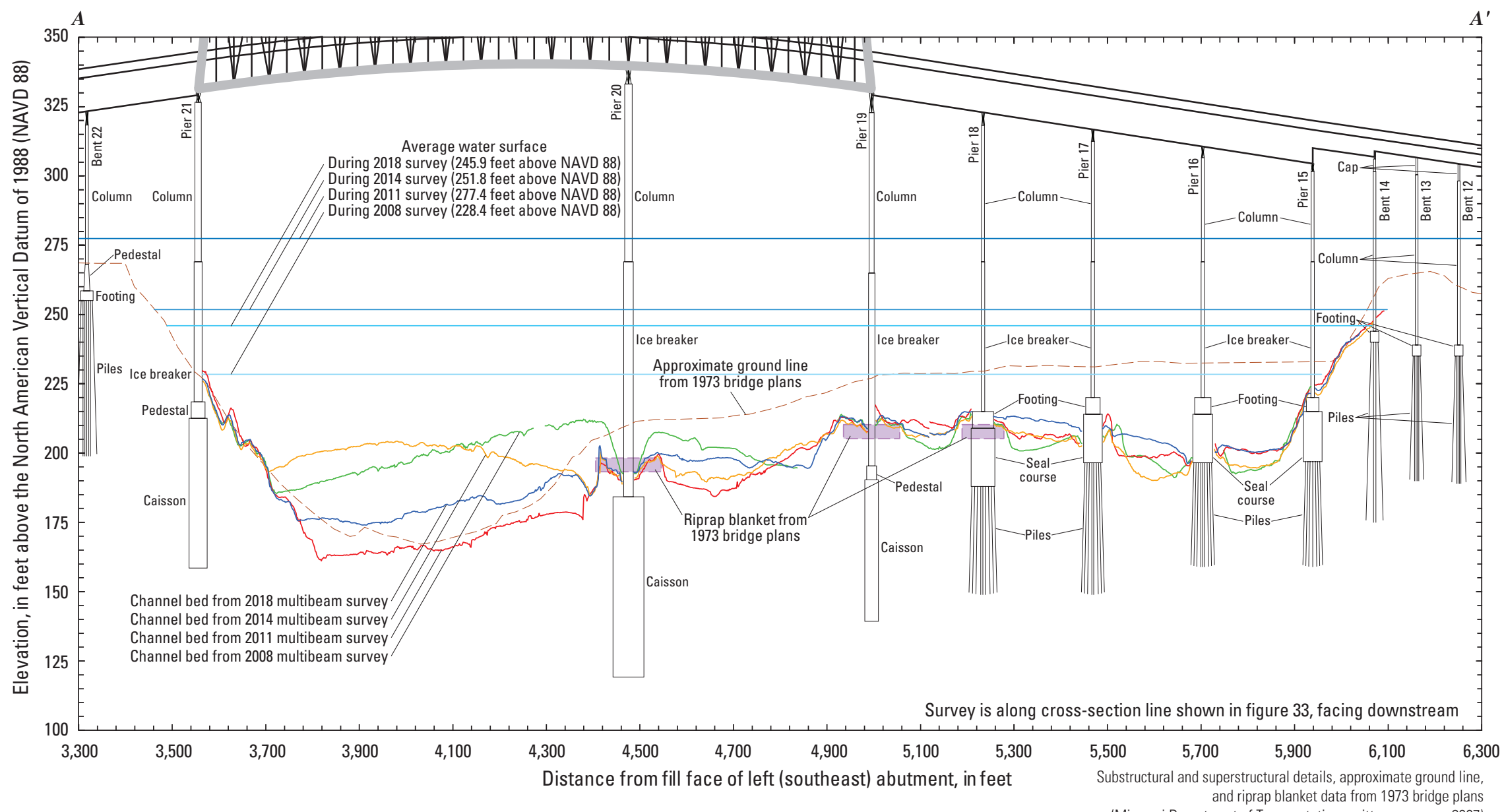

Figure 35. Key features, substructural and superstructural details, and surveyed channel bed of structure A1700 on Interstate 155 crossing the Mississippi River near Caruthersville, Missouri. 


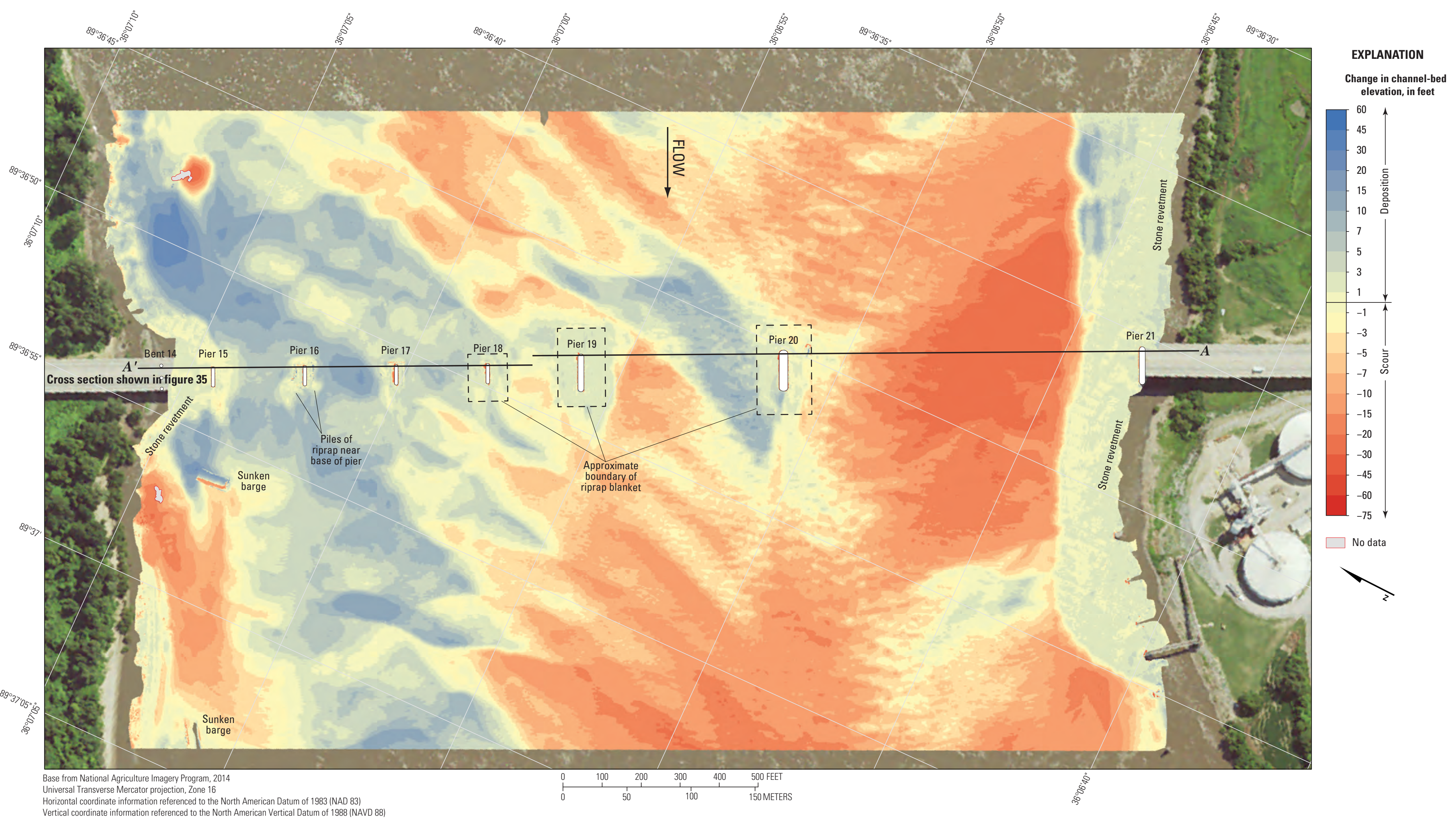

Figure 36. Difference between surfaces created from bathymetric surveys of the Mississippi River channel near structure A1700 on Interstate 155 near Caruthersville, Missouri, on July 26, 2018, and June 11, 2014. 


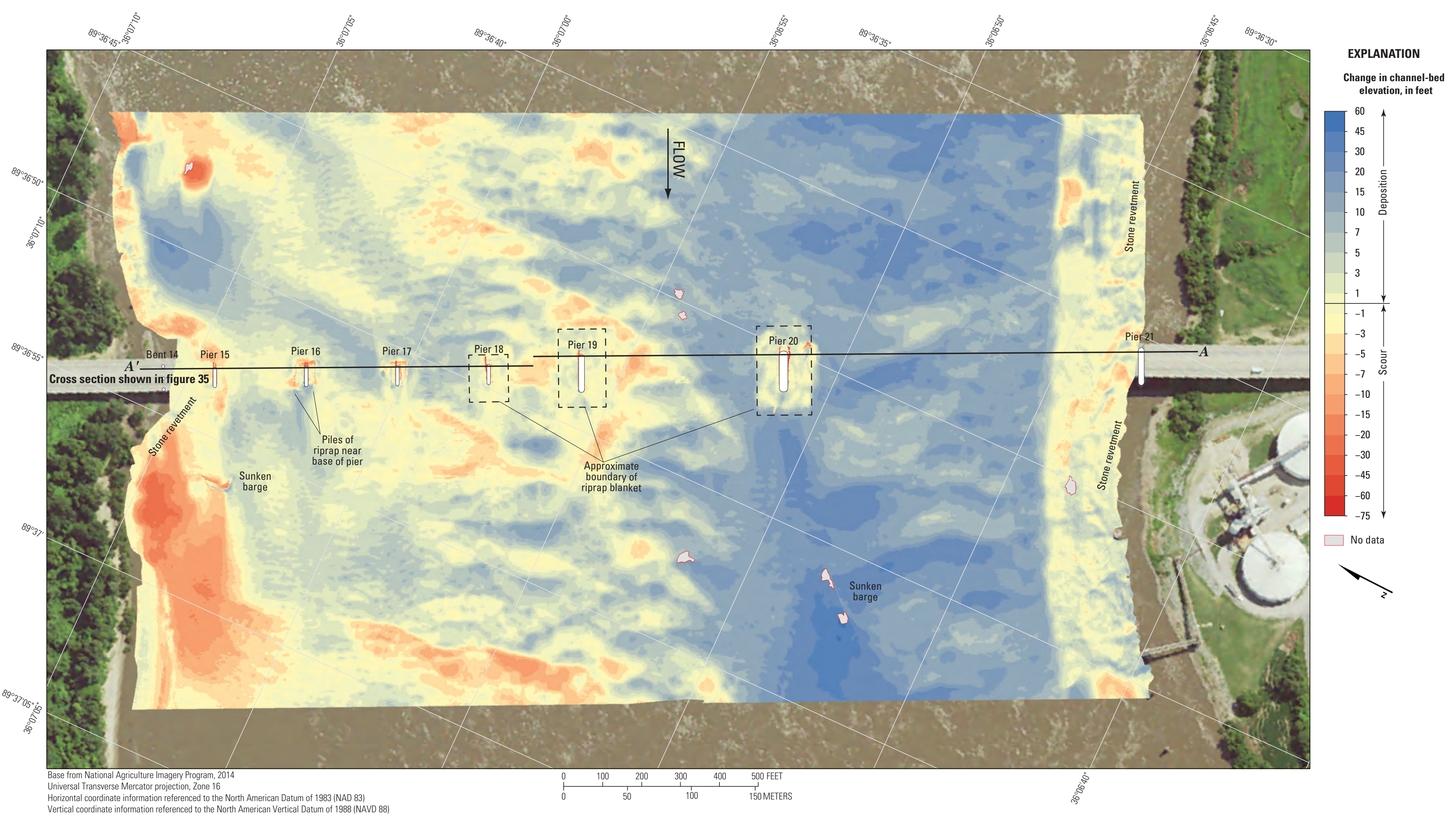

Figure 37. Difference between surfaces created from bathymetric surveys of the Mississippi River channel near structure A1700 on Interstate 155 near Caruthersville, Missouri, on July 26, 2018, and May 5, 2011. 


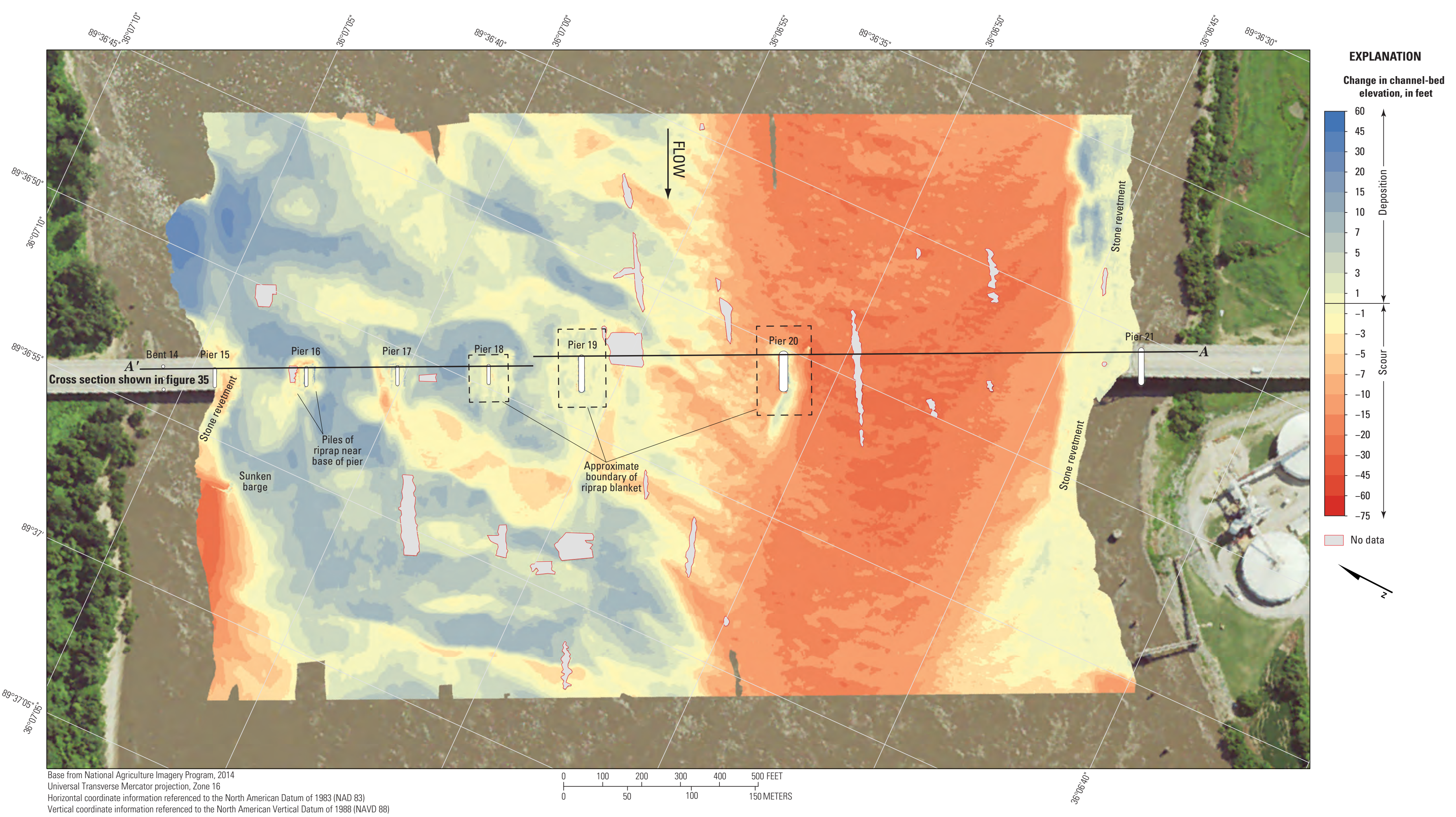

Figure 38. Difference between surfaces created from bathymetric surveys of the Mississippi River channel near structure A1700 on Interstate 155 near Caruthersville, Missouri, on July 26, 2018, and December 10, 2008. 


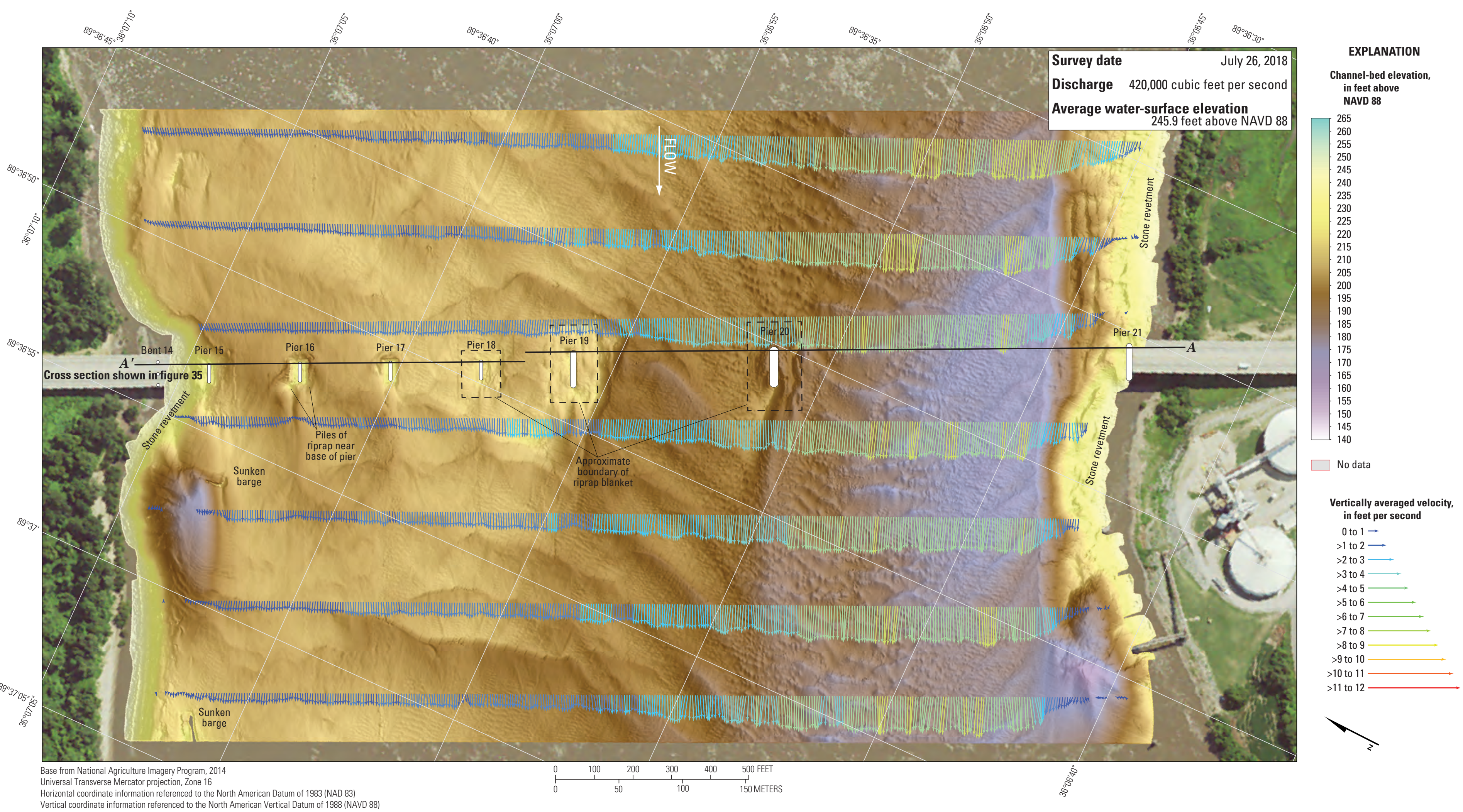

Figure 39. Bathymetry and vertically averaged velocities of the Mississippi River channel near structure A1700 on Interstate 155 near Caruthersville, Missouri. 
bathymetric surfaces were $0.01 \mathrm{ft}$ and $3.15 \mathrm{ft}$ for Brownville (site 1) and St. Joseph (site 2), respectively, which indicates deposition (table 8). Alternatively, streamflows at the Missouri River sites during the 2018 surveys ranged from 35 to 44 percent of the 2011 streamflows, with water-surface elevations about 7 to $11 \mathrm{ft}$ lower in 2018 than in 2011 (table 8), and yet the average differences between the 2018 and 2011 bathymetric surfaces were $3.77 \mathrm{ft}$ and $0.86 \mathrm{ft}$ at Brownville (site 1) and St. Joseph (site 2), respectively, which again indicates deposition (table 8). The smaller average differences between surveys might be considered equivocal, based on the uncertainty associated with points as indicated by the TPU values recorded for the surveys (table 6). Nevertheless, these trends are not in keeping with what might be expected for scour and deposition based purely on streamflow. The average difference in bed elevation at Brownville (site 1) indicated substantial deposition from 2011 to 2018, whereas there was little change between 2014 and 2018 (table 8). The average difference in bed elevation at St. Joseph (site 2) indicated minor to moderate deposition between 2011 and 2018, and substantial deposition between 2014 and 2018; however, this may be the result of the limited area surveyed in 2014 at this site, or an artifact of the dredging activity in the area in 2014 mentioned in the earlier "Dual Bridge Structure A3664 on U.S. Highway 36 at St. Joseph, Missouri" section.

Streamflows at the Mississippi River sites during the 2018 surveys ranged from about 67 to 88 percent of the 2014 streamflows, with water-surface elevations about 0.6 to $5.9 \mathrm{ft}$ lower in 2018 than in 2014 (table 8). The average difference between the bathymetric surfaces varied from $3.4 \mathrm{ft}$ lower to $1.5 \mathrm{ft}$ higher in 2018 than 2014, tending towards positive values, which indicates deposition (table 8). Again, some of the smaller average differences between surveys might be considered equivocal, based on the uncertainty associated with points as indicated by the TPU values recorded for the surveys (table 6). Nevertheless, these trends are generally more consistent with what might be expected for scour and deposition based purely on streamflow.

The dune features at both sites on the Missouri River in the 2018 surveys were small to medium in size. At structure L0098 at Brownville, Neb., (site 1, fig. 1), the dune features have been small to medium for all the surveys at that site, regardless of the flow conditions (fig. 6; Huizinga, 2012, 2015). However, at dual bridge structure A3664 at St. Joseph, Mo. (site 2, fig. 1), the dune features have varied greatly, with large dune features during the flooding of 2011 (Huizinga, 2012), small dune features during lower flow conditions in 2014 (Huizinga, 2015), and small to medium dune features in 2018 (fig. 12). The variation in dune sizes appears loosely related to the flow regime at St. Joseph, but independent of flow regime at Brownville.

The dune features at the Mississippi River sites in the 2018 surveys generally were similar to those in the 2014 surveys, except at Cape Girardeau. The flow at structure A5076 at Cape Girardeau, Mo. (site 37, fig. 1) in 2018 was 75 percent of the flow in 2014, and the dune features were smaller in 2018 (fig. 28; Huizinga, 2015). Conversely, the flow at structure A1700 near Caruthersville, Mo. (site 38, fig. 1) in 2018 was 67 percent of the flow in 2014, the lowest ratio seen in 2018; however, similar dune features and sizes were observed between 2014 and 2018 (fig. 33; Huizinga, 2015).

An examination of the frequency distributions of bed elevations (figs. 7, 13, 19, 24, 29, and 34) indicate that the 2018 distributions generally are similar to the 2014 distributions, which might be expected given the generally similar flow conditions or flow regime between 2014 and 2018. However, there is a difference in the distributions at St. Joseph (site 2, fig. 13), which likely is the result of the dredging operation in progress in 2014 as mentioned earlier in this section. A difference in distribution at Caruthersville (site 38, fig. 34) may be the result of the timing of the 2018 survey after the longer-duration high flow on the Mississippi River, compared to being on the rising limb of a flood in 2014 (Huizinga, 2015). The 2018 accumulation curve generally falls between the 2011 distribution and the 2008 and 2014 distributions at Caruthersville (fig. 34); the 2014 distribution is very similar to the 2008 distribution (fig. 34), despite the substantially different flows.

\section{Effects of Riprap Blankets near Piers}

Several of the piers at the Mississippi River bridges had riprap blankets or piles of rock surrounding them (figs. 18, 28, 33). It is unknown whether all these features were specifically designed to resist scour, were an ad hoc placement of riprap to mitigate observed exposure of a particular substructural bridge element, or if they simply were construction detritus. Nevertheless, the presence of these features had a substantial effect on the observed scour at a given pier, particularly when compared to other piers at the same site without such a feature.

Piers 18 through 20 of structure A1700 near Caruthersville, Mo. (site 38, fig. 1), were surrounded by riprap blankets (fig. 33) that were a minimum of $5 \mathrm{ft}$ thick per the 1973 bridge plans (Missouri Department of Transportation, written commun., 2007; fig. 35). The blankets limited pier scour near piers 18 and 19 in all of the surveys, and prevented additional scour near pier 20 during the three later surveys at the site, including the substantial flood of 2011 (Huizinga, 2015). A scour hole was observed in material deposited on top of the blanket near pier 20 during the 2008 survey (fig. 35). The top surface of the blanket around pier 20 is very irregular (fig. 33), and seemed to have a depression adjacent to the pier that seems to penetrate the top of the blanket (fig. 35), which may have been the result of back-filling an existing scour hole or other low spot when the blanket was installed, per 1973 bridge plans (Missouri Department of Transportation, written commun., 2007). The random piles of riprap around the base of pier 16 (fig. 33) may help mitigate scour near that pier.

Several other piers seemed partially surrounded by random piles of riprap or rock, which may or may not help mitigate scour near those piers. Piers 9 and 10 of structure A5054 at Hannibal, Mo. (site 31, fig. 1), have hummocks on 
either side that may be partial riprap blankets (fig. 18), and piers 3 and 4 of structure A5076 at Cape Girardeau, Mo. (site 37, fig. 1), seemed to be partially surrounded with piles of coarse material (fig. 28). However, the effectiveness of the scour mitigation is uncertain, because the placement seems random and non-uniform. Furthermore, there are no indications of designed scour countermeasures at these sites in the bridge plans. Scour immediately downstream from piers 3 and 4 of structure A5076 at Cape Girardeau, Mo., was substantial (fig. 28), but likely does not directly affect the stability of those piers.

\section{Size and Shape of Scour Holes}

Generally, every pier in the main channel area for which bathymetry could be obtained had some sort of scour hole, except those on banks, on bedrock, or surrounded by riprap. However, the size and shape of these holes were different from one bridge to the next and occasionally even at the same bridge site. The factors affecting the size and shape of the pier scour holes have been discussed in previous survey reports (Huizinga, 2012, 2014, 2015, 2016, 2017a, 2020a), and in some cases, the frontal slope of the various scour holes has been determined. Frontal slopes were not computed for the sites in this (2018) study. However, the factors that affect the local pier scour equation in Richardson and Davis (2001), including the depth and velocity of approach flow, the width and nose shape of the pier, the angle of approach flow, and the condition and armoring of the channel bed, are discussed below.

For the various bridges in this study, flow velocities generally were greater in the deeper parts of the channel (the thalweg), and lower in the shallow parts of the channel, which is consistent with previous surveys. Of course, there were local exceptions, such as downstream from a spur dike where a local deep area may have had a low velocity (for example, figs. 11, 17, and 32). Exceptions notwithstanding, the size of the scour holes at sites having more than one pier in the water was related to the depth and velocity of flow upstream from the pier in question, and consistent with the local pier scour equation in Richardson and Davis (2001). Deeper flow or higher velocity generally resulted in larger, deeper scour holes than shallow flow or lower velocities (figs. 22, 27, 32, and 39 ) in the absence of bedrock or riprap as a designed scour countermeasure (piers 18 through 20, fig. 39). Similar findings have been observed during the various studies using the MBMS in Missouri (Huizinga, 2010, 2011, 2012, 2014, 2015, 2016, 2017a, 2020a).

Also consistent with the local pier scour equation in Richardson and Davis (2001), piers having wide or blunt noses resulted in larger, deeper scour holes than those having narrow, round, or sharp noses. In fact, narrow piers having round or sharp noses that were aligned with flow often had scour holes that were difficult to discern from nearby small dunes and ripples (pier 10, fig. 12; pier 6, fig. 28). Scour holes generally were substantial near piers having blunt noses (piers
10 and 11, fig. 23; piers 3 and 4, fig. 28) and those that were rounded but wide relative to their length (pier 3, fig. 6). When the channel bed immediately upstream from a pier was above the top of a footing, the scour holes near that pier occasionally did not penetrate below the top of the footing (pier 10, figs. 12, 14; piers 9 and 11, figs. 18, 20; pier 6, figs. 28, 30); the footing effectively limited scour at these piers. However, if the upstream edge of the top of the footing was exposed, the substantial extra width of the footing tended to widen the scour hole (pier 8, figs. 18, 20; piers 4 and 5, figs. 28, 30; piers 16 and 17, figs. 33, 35). Similar findings have been observed during the various studies using the MBMS in Missouri (Huizinga, 2010, 2011, 2014, 2015, 2016, 2017a, 2020a), particularly during the 2011 flood (Huizinga, 2012).

Several of the surveyed bridges had piers that were skewed to approach flow, resulting in asymmetric scour holes at those piers: all the piers of structure A5054 on Interstate 72 at Hannibal, Mo. (fig. 18), and piers 3 and 4 of structure A5076 on State Highway 34 at Cape Girardeau, Mo. (fig. 28). The scour hole typically was deeper and longer on the side of the pier with impinging flow, with some amount of deposition on the leeward side. The channel bed near pier 20 of structure A1700 on Interstate 155 near Caruthersville, Mo., also displays these features (fig. 33), likely as a result of the contraction and deflection of flow caused by the stone revetment on the downstream left (south) bank.

\section{Summary and Conclusions}

Bathymetric and velocimetric data were collected near 7 highway bridges at 6 crossings of the Missouri and Mississippi Rivers on the periphery of Missouri by the U.S. Geological Survey in cooperation with the Missouri Department of Transportation. A multibeam echosounder mapping system was used to obtain channel-bed elevations for areas about 1,640 feet (ft) longitudinally and generally extending across the active channel from bank to bank in the Missouri and Mississippi Rivers during moderate flood-flow conditions. These surveys document the channel-bed conditions and velocity distribution at the time of the surveys and provide characteristics of scour holes that may be useful in the development of predictive guidelines or equations for scour holes. These data also may be used by the Missouri Department of Transportation as a moderate flow comparison to help assess the bridges for stability and integrity issues with respect to bridge scour during floods.

The estimated total propagated uncertainty for the bathymetric surface of each survey area was computed as an estimate of the accuracy to be expected for each point with all relevant sources of error taken into account. An analysis of the surveys indicated that more than 98 percent of the bathymetric data at all the sites have a total propagated uncertainty of 
less than $0.50 \mathrm{ft}$, and more than 77 percent of the channel-bed elevations at the sites have a total propagated uncertainty of less than $0.25 \mathrm{ft}$.

Bathymetric data were collected around every pier that was in water, except those at the edge of water, and scour holes were observed at most surveyed piers. Scour holes were present at most piers for which bathymetry could be obtained, except those on banks, on bedrock, or surrounded by riprap. Occasionally, the scour hole near a pier was difficult to discern from nearby bed features. The observed scour holes at the surveyed bridges were generally examined with respect to shape and depth. At all the surveyed bridges, a variety of fluvial geomorphic features were detected in the channel, ranging from small ripples to large dunes that indicate moderate transport of bedload.

Although exposure of parts of substructural support elements was observed at several piers, at most sites the exposure likely can be considered minimal compared to the overall substructure that remains buried in bed material at these piers. The notable exceptions are piers 12 and 13 at structure L0135 on State Highway 51 at Chester, Illinois, at which the bedrock material was fully exposed around the piers. In modern construction, bridge substructural elements usually are pinned or socketed to bedrock, but full exposure of usually buried substructural elements warrants special consideration and observation.

Streamflows at the Missouri Rivers sites during the 2018 surveys were 1.5 to 2.0 times greater than the 2014 streamflows, and water-surface elevations were 6.0 to $7.9 \mathrm{ft}$ higher in 2018 than in 2014. Alternatively, streamflows at the Missouri River sites during the 2018 surveys ranged from 35 to 44 percent of the 2011 streamflows, with water-surface elevations about 7 to $11 \mathrm{ft}$ lower in 2018 than in 2011. However, both Missouri River sites generally displayed deposition from the previous surveys to 2018, despite the opposite nature of the difference in streamflow conditions. The substantial deposition observed between 2014 and 2018 at St. Joseph, Missouri, might be the result of dredging activity in progress during the 2014 survey. Streamflows at the Mississippi River sites during the 2018 surveys ranged from about 67 to 88 percent of the 2014 streamflows, with water-surface elevations about 0.6 to $5.9 \mathrm{ft}$ lower in 2018 than in 2014. The average difference between the 2018 and 2014 bathymetric surfaces varied from $-3.4 \mathrm{ft}$ to $+1.5 \mathrm{ft}$, tending towards positive values indicating deposition, which generally is more consistent with the ratio of streamflows during the 2018 surveys compared to the previous surveys.

The presence of riprap blankets, pier size and nose shape, and alignment to flow had a substantial effect on the size of the scour hole observed at a given pier. Piers that were surrounded by riprap blankets had scour holes that were substantially smaller (to non-existent) compared to piers at which no rock or riprap was present. Narrow piers having round or sharp noses that were aligned with flow often had scour holes that were difficult to discern from nearby bed features, whereas piers having wide or blunt noses resulted in larger, deeper scour holes. Several of the structures had piers that were skewed to primary approach flow, and scour holes near these piers generally displayed deposition on the leeward side of the pier and greater depth on the side of the pier with impinging flow.

\section{References Cited}

\author{
American Association of State Highway Transportation \\ Officials, 2012, AASHTO LRFD bridge design speci- \\ fications, Section 10, (Customary U.S. Units, 6th ed.): \\ Washington, D.C., 167 p.
}

Applanix Corporation, 2017, POSPac MMS GNSS-inertial tools software, rev. 15: Richmond Hill, Ontario, Canada, PUBS-MAN-001768, 246 p.

Brown, D.A., Turner, J.P., and Castelli, R.J., 2010, Drilled shafts-Construction procedures and LRFD Design Methods: U.S. Federal Highway Administration Publication FHWA-NHI-10-016 Geotechnical Engineering Circular no. $10,970 \mathrm{p}$.

Calder, B.R., and Mayer, L.A., 2003, Automatic processing of high-rate, high-density multibeam echosounder data: Geochemistry, Geophysics, Geosystems ( $\left.\mathrm{G}^{3}\right)$, v. 4, no. 6, 22 p. [Also available at https://doi.org/10.1029/ 2002GC000486.]

Czuba, J.A., Best, J.L., Oberg, K.A., Parsons, D.R., Jackson, P.R., Garcia, M.H., and Ashmore, P., 2011, Bed morphology, flow structure, and sediment transport at the outlet of Lake Huron and in the Upper Saint Clair River: Journal of Great Lakes Research, v. 37, no. 3, p. 480-493. [Also available at https://doi.org/10.1016/j.jglr.2011.05.011.]

Densmore, B.K., Strauch, K.R., and Dietsch, B.J., 2013, Hydrographic surveys of the Missouri and Yellowstone Rivers at selected bridges and through Bismarck, North Dakota, during the 2011 flood: U.S. Geological Survey Scientific Investigations Report 2013-5087, 59 p. [Also available at https://doi.org/10.3133/sir20135087.]

Dietsch, B.J., Densmore, B.K., and Strauch, K.R., 2014, Hydrographic surveys at selected highway bridges crossing the Missouri River using a multibeam echosounder, 2011: U.S. Geological Survey Scientific Investigations Report 2014-5062, 53 p. [Also available at https://doi.org/10.3133/ sir20145062.]

Esri, 2020, ArcGIS: Environmental Systems Research Institute (Esri): accessed February 2020 at https://www.esri.com/ software/arcgis/. 
Gilbert, G.K., and Murphy, E.C., 1914, The transportation of debris by running water: U.S. Geological Survey Professional Paper 86, 263 p. [Also available at https://doi.org/10.3133/pp86.]

Huizinga, R.J., 2010, Bathymetric surveys at highway bridges crossing the Missouri River in Kansas City, Missouri, using a multibeam echo sounder, 2010: U.S. Geological Survey Scientific Investigations Report 2010-5207, 61 p. [Also available at https://doi.org/10.3133/sir20105207.]

Huizinga, R.J., 2011, Bathymetric surveys at highway bridges crossing the Missouri and Mississippi Rivers near St. Louis, Missouri, 2010: U.S. Geological Survey Scientific Investigations Report 2011-5170, 75 p. [Also available at https://doi.org/10.3133/sir20115170.]

Huizinga, R.J., 2012, Bathymetric and velocimetric surveys at highway bridges crossing the Missouri River in and into Missouri during summer flooding, July-August 2011: U.S. Geological Survey Scientific Investigations Report 2012-5204, 166 p. [Also available at https://doi.org/ 10.3133/sir20125204.]

Huizinga, R.J., 2013, Results of repeat bathymetric and velocimetric surveys at the Amelia Earhart Bridge on U.S. Highway 59 over the Missouri River at Atchison, Kansas, 2009-2013: U.S. Geological Survey Scientific Investigations Report 2013-5177, 50 p. [Also available at https://doi.org/10.3133/sir20135177.]

Huizinga, R.J., 2014, Bathymetric and velocimetric surveys at highway bridges crossing the Missouri River between Kansas City and St. Louis, Missouri, April-May, 2013: U.S. Geological Survey Scientific Investigations Report 2014-5116, 79 p. [Also available at https://doi.org/10.3133/ sir20145116.]

Huizinga, R.J., 2015, Bathymetric and velocimetric surveys at highway bridges crossing the Missouri and Mississippi Rivers on the periphery of Missouri, June 2014: U.S. Geological Survey Scientific Investigations Report 2015-5048, 81 p. [Also available at https://doi.org/10.3133/ sir20155048.]

Huizinga, R.J., 2016, Bathymetric and velocimetric surveys at highway bridges crossing the Missouri River near Kansas City, Missouri, June 2-4, 2015: U.S. Geological Survey Scientific Investigations Report 2016-5061, 93 p. [Also available at https://doi.org/10.3133/sir20165061.]

Huizinga, R.J., 2017a, Bathymetric and velocimetric surveys at highway bridges crossing the Missouri and Mississippi Rivers near St. Louis, Missouri, May 23-27, 2016: U.S. Geological Survey Scientific Investigations Report 2017-5076, 102 p. [Also available at https://doi.org/ 10.3133/sir20175076.]
Huizinga, R.J., 2017b, Bathymetry and velocity data from surveys at highway bridges crossing the Missouri and Mississippi Rivers near St. Louis, Missouri, October 2008 through May 2016: U.S. Geological Survey data release, https://doi.org/10.5066/F71C1VCC.

Huizinga, R.J., 2020a, Bathymetric and velocimetric surveys at highway bridges crossing the Missouri River between Kansas City and St. Louis, Missouri, May 22-31, 2017: U.S. Geological Survey Scientific Investigations Report 2020-5018, 104 p. [Also available at https://doi.org/ 10.3133/sir20205018.]

Huizinga, R.J., 2020b, Bathymetry and velocity data from surveys at highway bridges crossing the Missouri River in Kansas City, Missouri, March 2010 through May 2017: U.S. Geological Survey data release, https://doi.org/10.5066/ P9L6GW57/.

Huizinga, R.J., 2020c, Bathymetry and velocity data from surveys at highway bridges crossing the Missouri River between Kansas City and St. Louis, Missouri, January 2010 through May 2017: U.S. Geological Survey data release, https://doi.org/10.5066/P94M4US7.

Huizinga, R.J., 2020d, Bathymetry and velocity data from surveys at highway bridges crossing the Missouri and Mississippi Rivers on the periphery of Missouri, December 2008 through August 2018: U.S. Geological Survey data release, https://doi.org/10.5066/P9WDI9YF.

Huizinga, R.J., Elliott, C.M., and Jacobson, R.B., 2010, Bathymetric and velocimetric survey and assessment of habitat for pallid sturgeon on the Mississippi River in the vicinity of the proposed Interstate 70 Bridge at St. Louis, Missouri: U.S. Geological Survey Scientific Investigations Report 2010-5017, 28 p. [Also available at https://doi.org/ 10.3133/sir20105017.]

Huizinga, R.J., and Rydlund, P.H., Jr., 2004, Potentialscour assessments and estimates of scour depth using different techniques at selected bridge sites in Missouri: U.S. Geological Survey Scientific Investigations Report 2004-5213, 42 p. [Also available at https://doi.org/10.3133/ sir20045213.]

HYPACK, Inc., 2018, HYPACK hydrographic survey software user manual: Middletown, Conn., HYPACK, Inc., 2434 p., accessed February 2020 at https:/www.hypack.com/file\%20 library/resource\%20library/manuals/2018/2018-hypackuser-manual.pdf.

International Hydrographic Organization, 2008, IHO standards for hydrographic surveys (5th ed.): Monaco, International Hydrographic Bureau, Special publication No. 44, 27 p. 
Lagasse, P.F., Shall, J.D., Johnson, F., Richardson, E.V., Richardson, J.R., and Chang, F., 1991, Stream stability at highway structures: U.S. Federal Highway Administration Publication FHWA-IP-90-014, Hydraulic Engineering Circular no. 20, 195 p.

Mueller, D.S., Wagner, C.R., Rehmel, M.S., Oberg, K.A., and Rainville, F., 2013, Measuring discharge with acoustic Doppler current profilers from a moving boat (ver. 2.0, December 2013): U.S. Geological Survey Techniques and Methods, book 3, chap. A22, 95 p. [Also available at https://doi.org/10.3133/tm3A22.]

National Marine Electronics Association, 2002, NMEA 0183 - Standard for interfacing marine electronic devices (ver. 3.01). National Marine Electronics Association, 88 p.

Parsons, D.R., Jackson, P.R., Czuba, J.A., Engel, F.L., Rhoads, B.L., Oberg, K.A., Best, J.L., Mueller, D.S., Johnson, K.K., and Riley, J.D., 2013, Velocity Mapping Toolbox (VMT) - A processing and visualization suite for movingvessel ADCP measurements: Earth Surface Processes and Landforms, v. 38, no. 11, p. 1244-1260. [Also available at https://doi.org/10.1002/esp.3367.]

Richardson, E.V., and Davis, S.R., 2001, Evaluating scour at bridges (4th ed.): U.S. Federal Highway Administration Publication FHWA NHI 01-001, Hydraulic Engineering Circular no. 18, 378 p.

Rydlund, P.H., Jr., 2009, Real-time river channel-bed monitoring at the Chariton and Mississippi Rivers in Missouri, 2007-09: U.S. Geological Survey Scientific Investigations Report 2009-5254, 27 p. [Also available at https://doi.org/ 10.3133/sir20095254.]

Simons, D.B., and Richardson, E.V., 1966, Resistance to flow in alluvial channels: U.S. Geological Survey Professional Paper 422-J, 61 p. [Also available at https://doi.org/ 10.3133/pp422J86.]
Simons, Li and Associates, 1985, Seasonal effects of river stage-discharge relations at selected gages, Final Report: Fort Collins, Colorado, prepared for U.S. Army Corps of Engineers, Contract No. DACW43-85-D-0017, 96 p.

U.S. Army Corps of Engineers, 2004a, Upper Mississippi River System flow frequency study, appendix F: Rock Island, Ill., U.S. Army Corps of Engineers, accessed February 2020 at https://www.mvr.usace.army.mil/Portals/ 48/docs/FRM/UpperMissFlowFreq/App. $\% 20$ F\%20 Omaha\%20Dist.\%20Hydrology_Hydraulics\%20Report.pdf.

U.S. Army Corps of Engineers, 2004b, Upper Mississippi River System flow frequency study, appendix E: Rock Island, Ill., U.S. Army Corps of Engineers, accessed February 2020 at https://www.mvr.usace.army.mil/Portals/ 48/docs/FRM/UpperMissFlowFreq/App.\%20E\%20 Kansas\%20City\%20Dist.\%20Hydrology_Hydraulics.pdf.

U.S. Army Corps of Engineers, 2004c, Upper Mississippi River System flow frequency study, appendix C: Rock Island, Ill., U.S. Army Corps of Engineers, accessed February 2020 at https://www.mvr.usace.army.mil/Portals/ 48/docs/FRM/UpperMissFlowFreq/App. $\% 20$ C $\% 20$ Rock\%20Island\%20Dist.\%20Mississippi\%20River\%20 Hydrology_Hydraulics.pdf.

U.S. Army Corps of Engineers, 2004d, Upper Mississippi River System flow frequency study, appendix D: Rock Island, Ill., U.S. Army Corps of Engineers, accessed February 2020 at https://www.mvr.usace.army.mil/Portals/ 48/docs/FRM/UpperMissFlowFreq/App.\%20D\%20St.\%20 Louis\%20Dist.\%20Hydrology_Hydraulics.pdf.

U.S. Army Corps of Engineers, 2013, Engineering and design-Hydrographic surveying: Washington D.C., U.S. Army Corps of Engineers, manual no. EM 1110-2-1003, $560 \mathrm{p}$.

U.S. Geological Survey, 2020, USGS water data for the Nation: U.S. Geological Survey National Water Information System database, accessed February 2020 at https://doi.org/10.5066/F7P55KJN. 


\section{Appendix 1. Shaded Triangulated Irregular Network Images of the Channel and Side of Pier for Each Surveyed Pier}

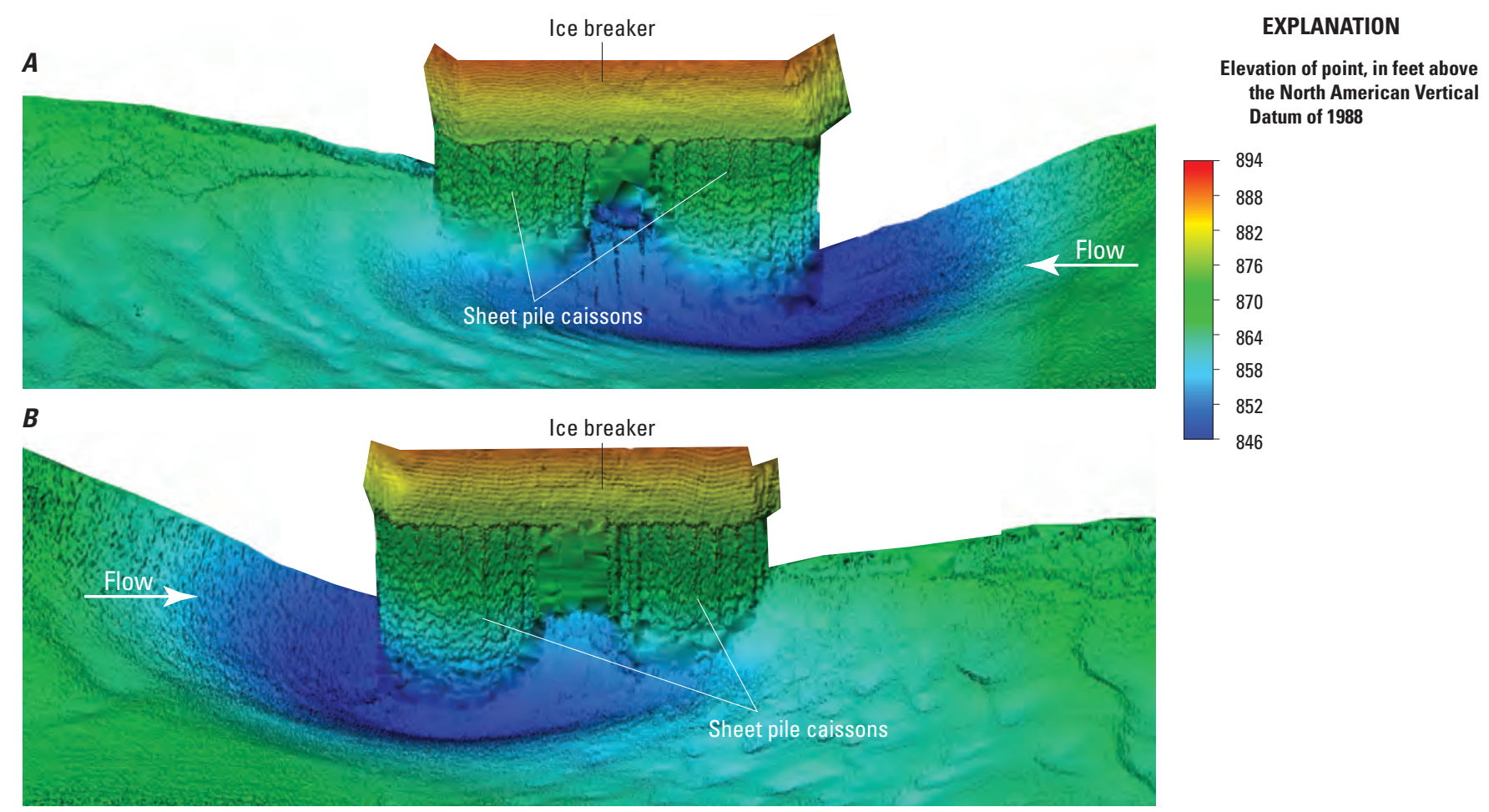

Figure 1.1. Shaded triangulated irregular network visualization of the channel bed and main channel pier of structure L0098 on U.S. Highway 136 over the Missouri River at Brownville, Nebraska. $A$, left (northeast) side of pier 3. B, right (southwest) side of pier 3. 

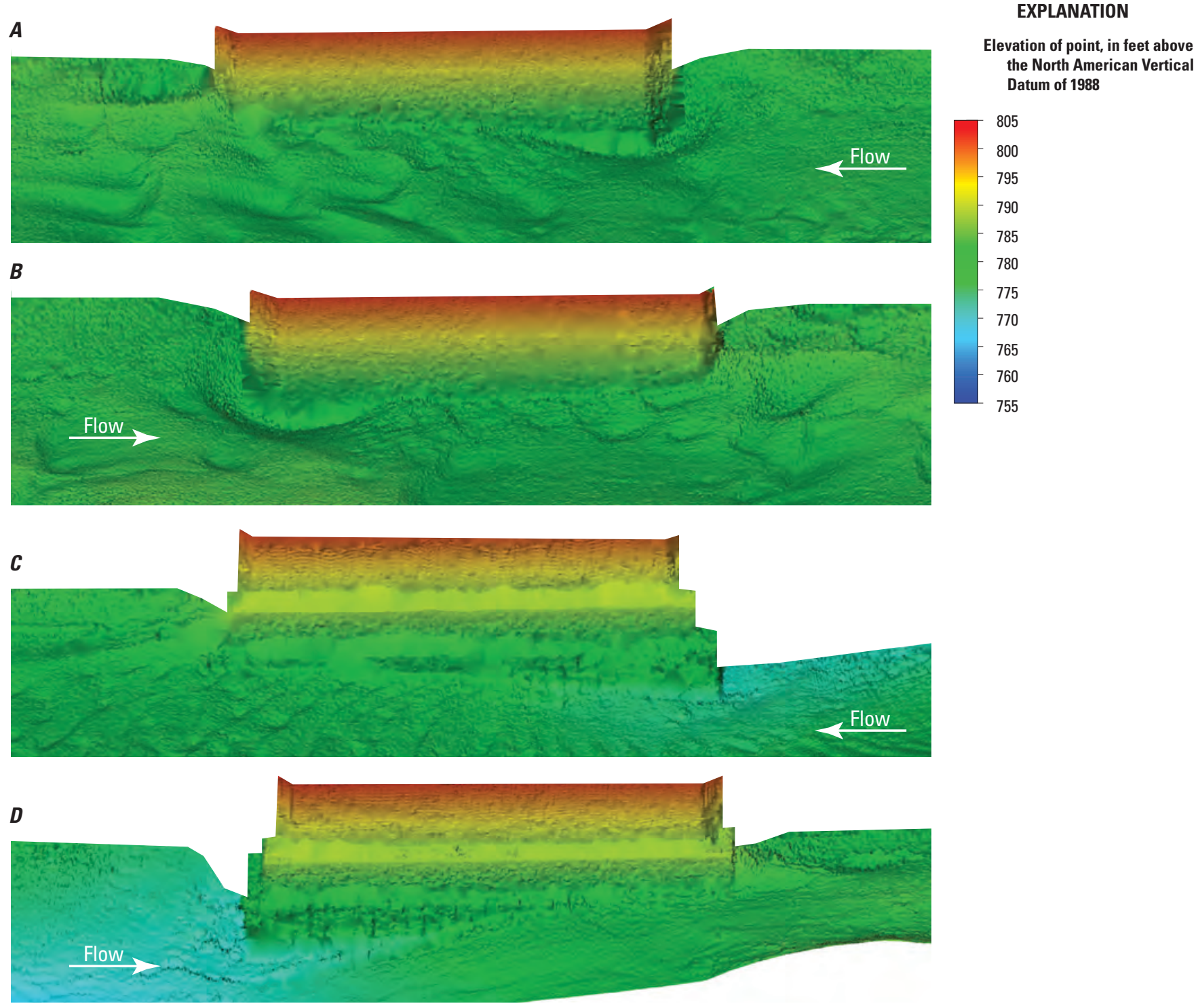

Figure 1.2. Shaded triangulated irregular network visualization of the channel bed and main channel piers of dual bridge structure A3664 on U.S. Highway 36 over the Missouri River at St. Joseph, Missouri. $A$, left (east) side of pier 10. B, right (west) side of pier 10. $C$, left (east) side of pier 9 . D, right (west) side of pier 9 . 
$\boldsymbol{A}$

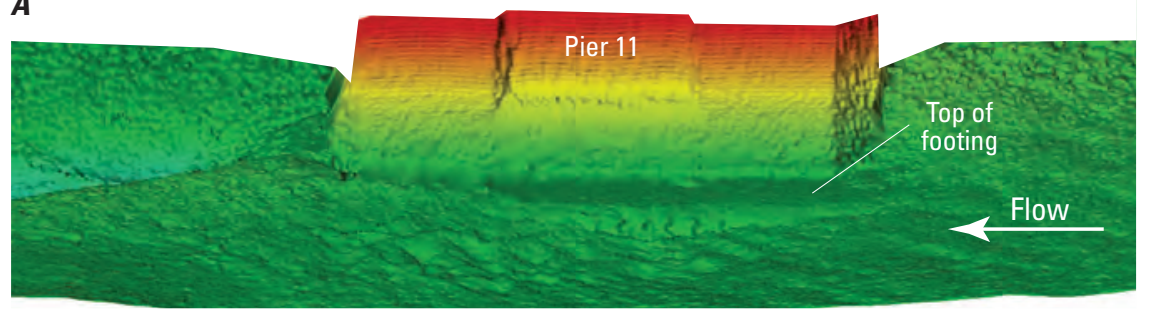

B
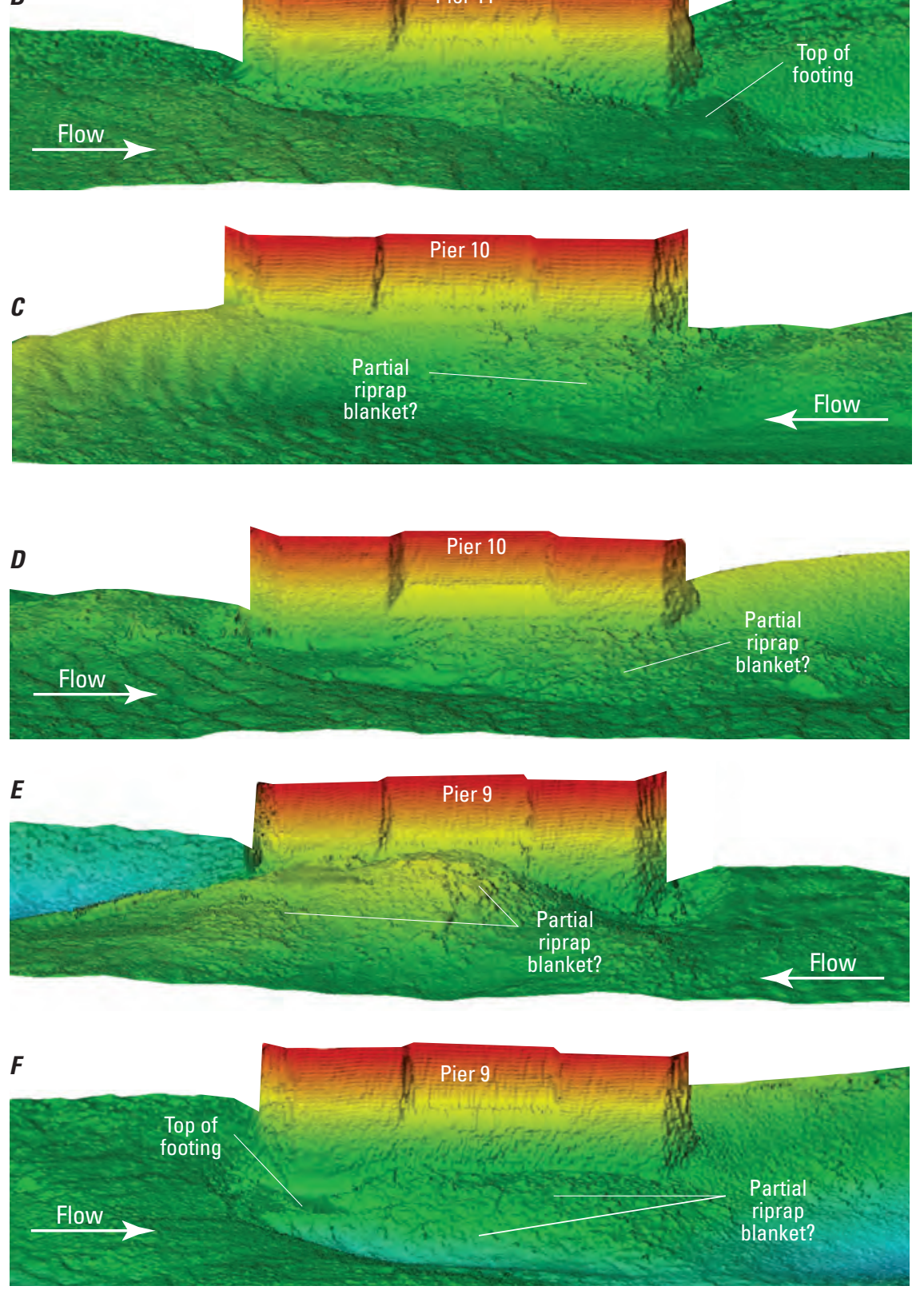

\section{EXPLANATION}

Elevation of point, in feet above the North American Vertical

Datum of 1988

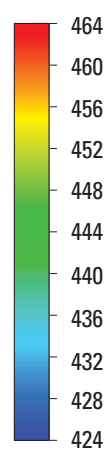

Figure 1.3. Shaded triangulated irregular network visualization of the channel bed and main channel piers of structure A5054 on Interstate 72 over the Mississippi River at Hannibal, Missouri. $A$, left (northeast) side of pier 11. B, right (southwest) side of pier 11. $C$, left (northeast) side of pier 10. D, right (southwest) side of pier 10. $E$, left (northeast) side of pier 9 . $F$, right (southwest) side of pier 9. 

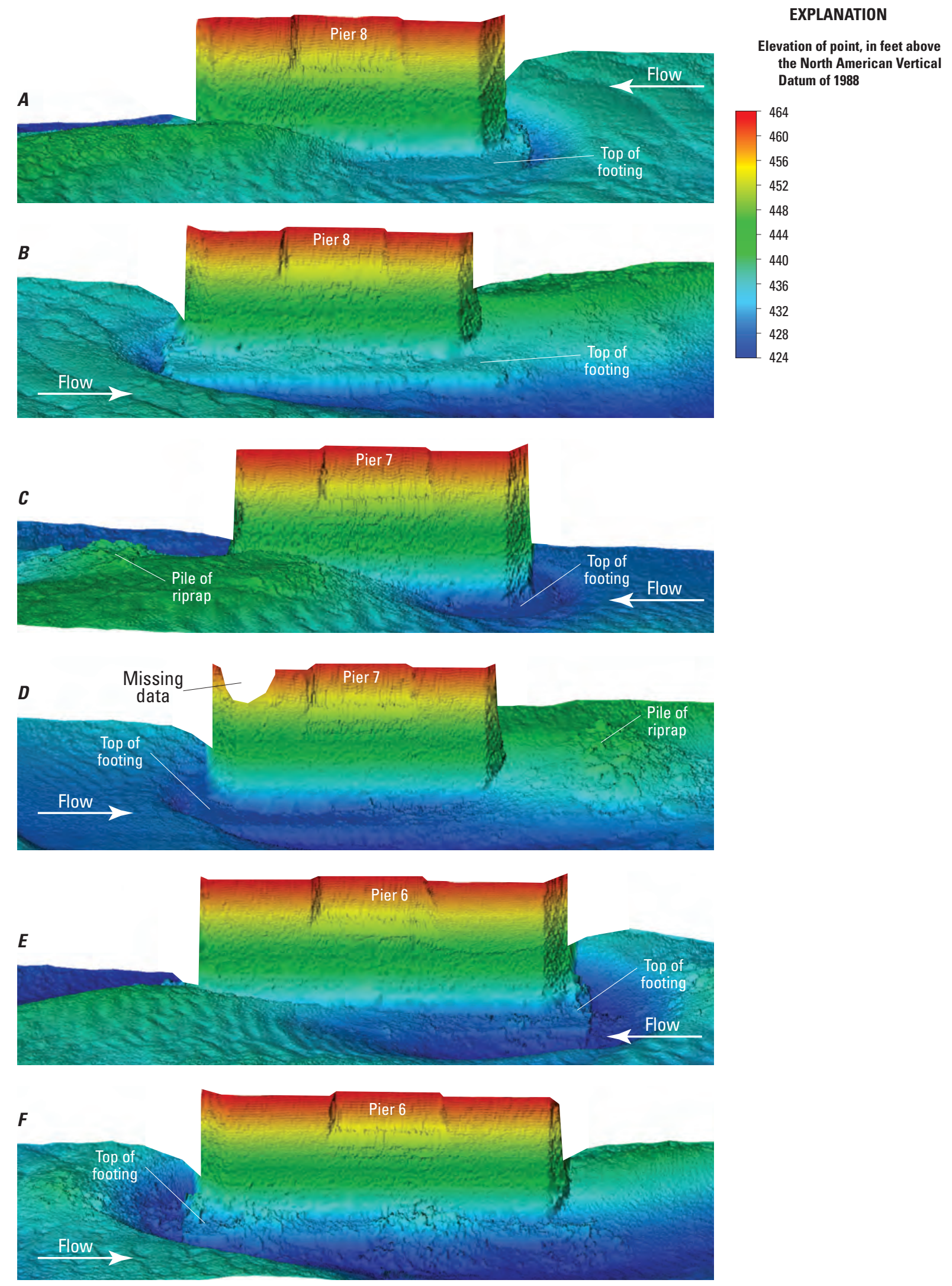

Figure 1.4. Shaded triangulated irregular network visualization of the channel bed and main channel piers of structure A5054 on Interstate 72 over the Mississippi River at Hannibal, Missouri. $A$, left (northeast) side of pier 8. B, right (southwest) side of pier 8. $C$, left (northeast) side of pier 7. D, right (southwest) side of pier 7. E, left (northeast) side of pier 6 . $F$, right (southwest) side of pier 6 . 

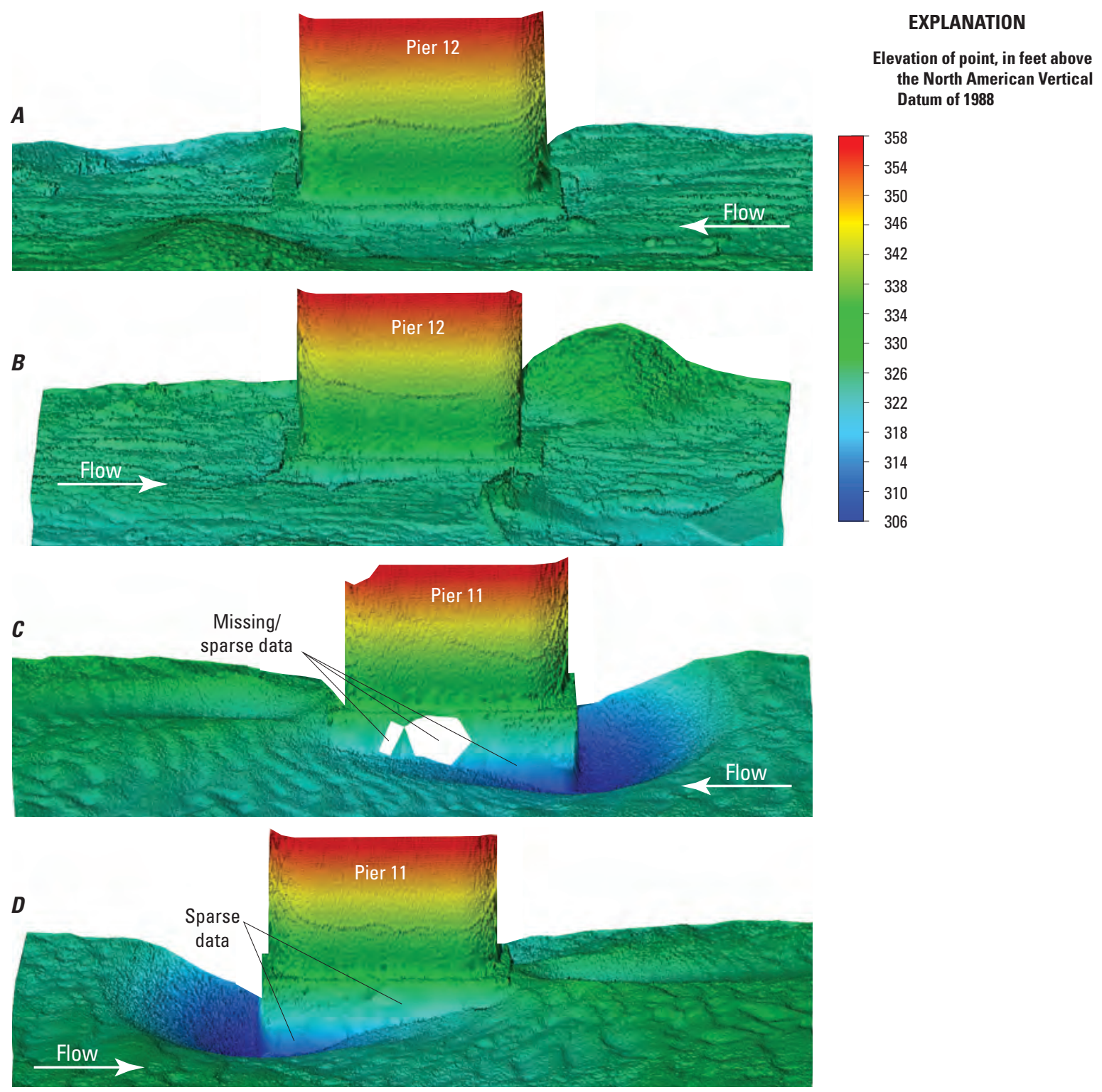

E
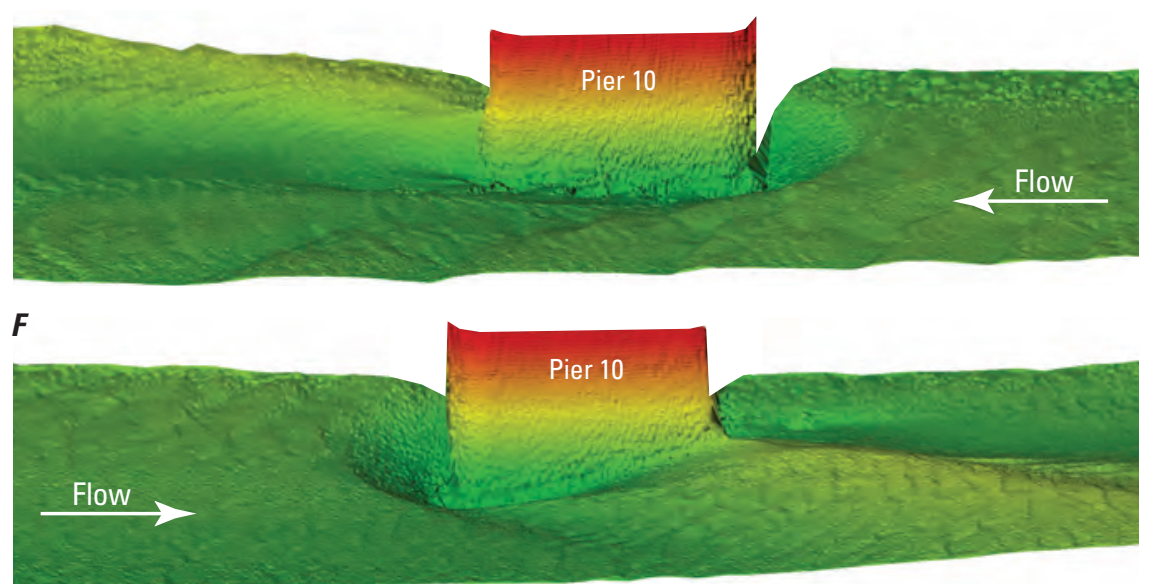

Figure 1.5. Shaded triangulated irregular network visualization of the channel bed and main channel piers of structure L0135 on State Highway 51 over the Mississippi River at Chester, Illinois. $A$, left (northeast) side of pier 12. B, right (southwest) side of pier 12. $C$, left (northeast) side of pier 11. D, right (southwest) side of pier 11. E, left (northeast) side of pier 10. F, right (southwest) side of pier 10. 
$\boldsymbol{A}$

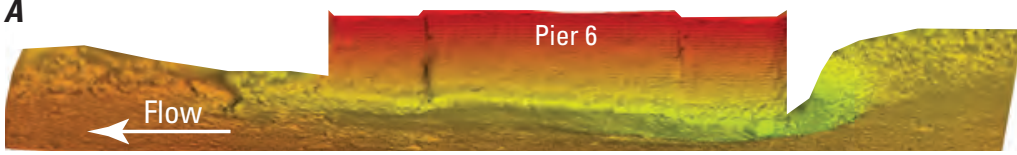

$\boldsymbol{B}$

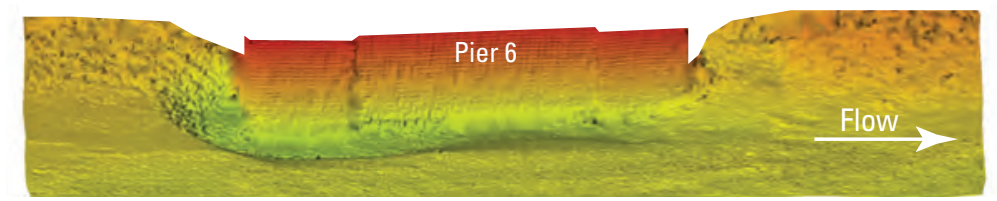

C

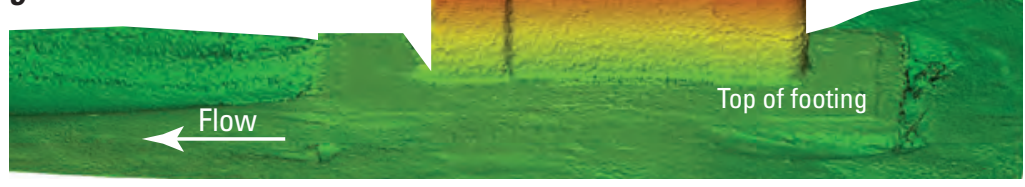

D
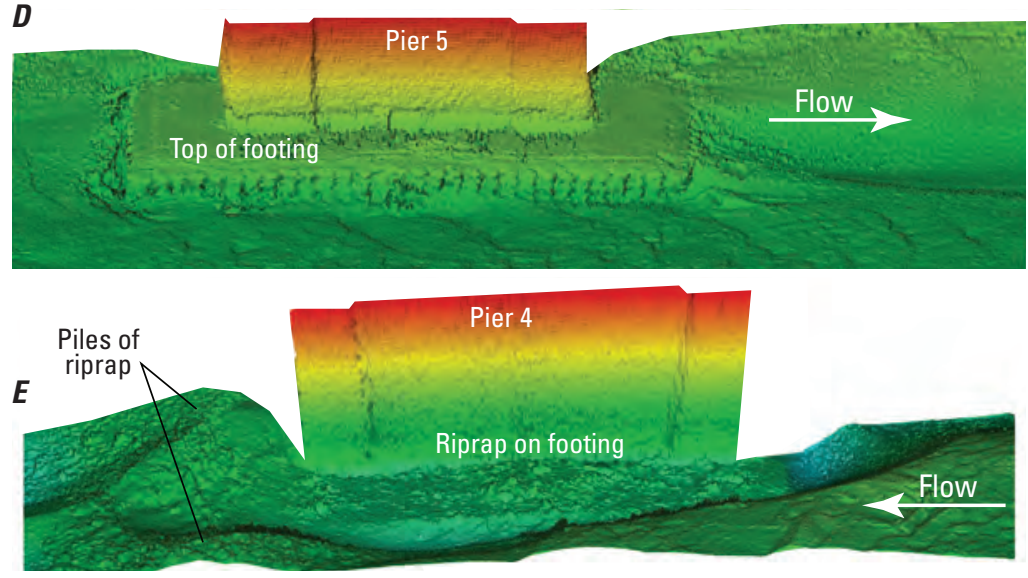

$\boldsymbol{F}$
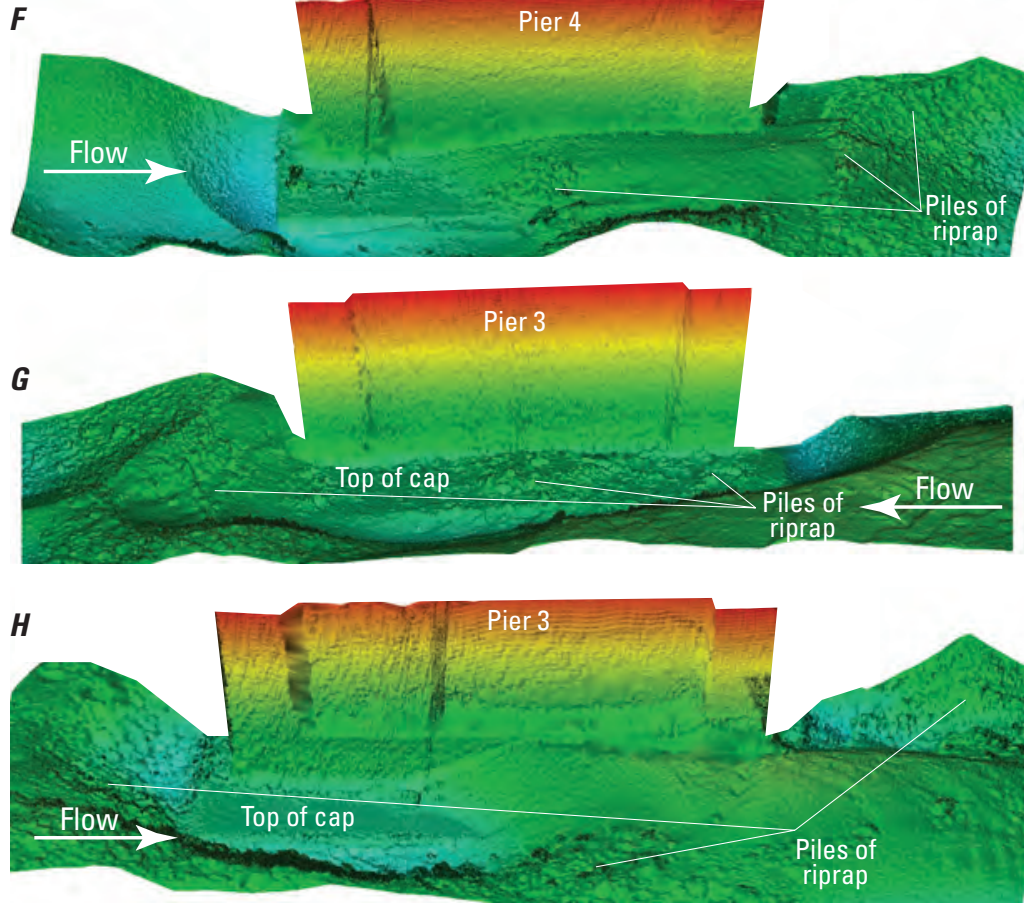

\section{EXPLANATION}

Elevation of point, in feet above the North American Vertical Datum of 1988

328

324

320

316

312

284

280

276
272

Figure 1.6. Shaded triangulated irregular network visualization of the channel bed and main channel piers of structure A5076 on State Highway 34 over the Mississippi River at Cape Girardeau, Missouri. $A$, left (east) side of pier 6. $B$, right (west) side of pier 6. $C$, left (east) side of pier 5. D, right (west) side of pier 5. E, left (east) side of pier 4. F, right (west) side of pier 4. G, left (east) side of pier 3. $H$, right (west) side of pier 3. 

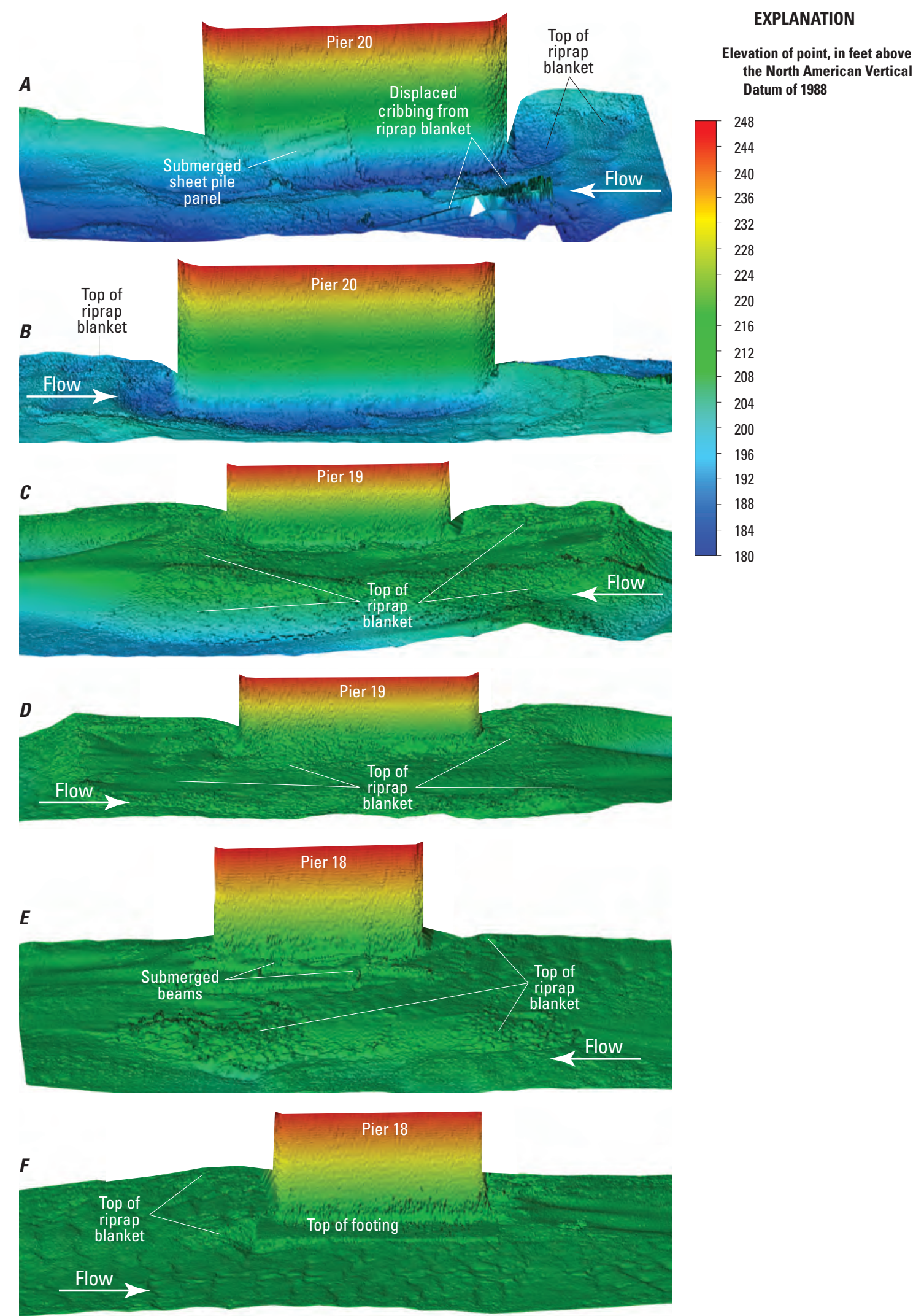

Figure 1.7. Shaded triangulated irregular network visualization of the channel bed and main channel piers of structure A1700 on Interstate 155 over the Mississippi River near Caruthersville, Missouri. $A$, left (southeast) side of pier 20. $B$, right (northwest) side of pier 20. $C$, left (southeast) side of pier 19. $D$, right (northwest) side of pier 19. $E$, left (southeast) side of pier 18. F, right (northwest) side of pier 18. 

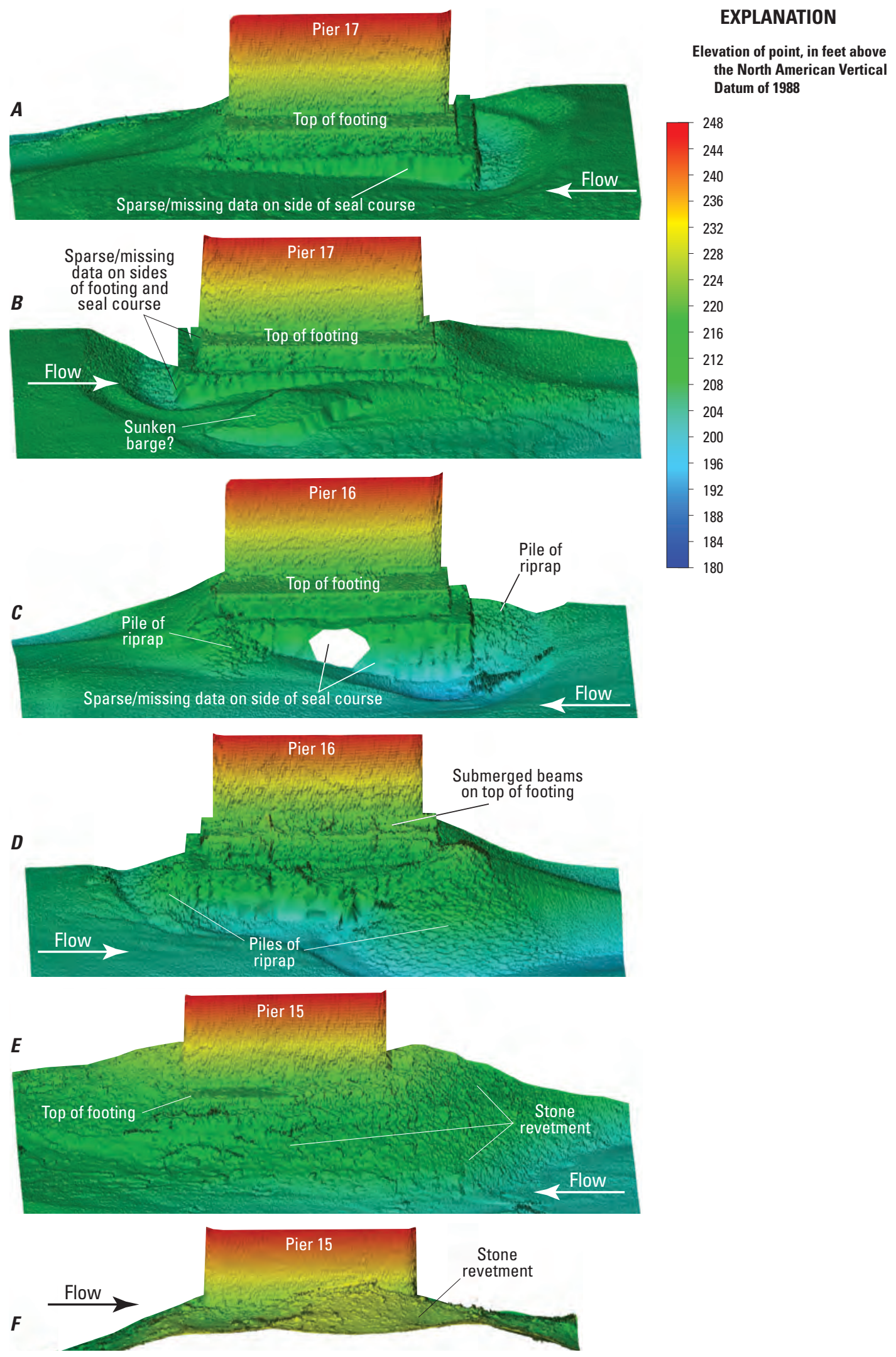

Figure 1.8. Shaded triangulated irregular network visualization of the channel bed and main channel piers of structure $A 1700$ on Interstate 155 over the Mississippi River near Caruthersville, Missouri. $A$, left (southeast) side of pier 17. $B$, right (northwest) side of pier 17. $C$, left (southeast) side of pier 16. D, right (northwest) side of pier 16. $E$, left (southeast) side of pier 15. F, right (northwest) side of pier 15. 
For more information about this publication, contact: Director, USGS Central Midwest Water Science Center 1400 Independence Road

Rolla, M0 65401

573-308-3667

For additional information, visit: https://www.usgs.gov/centers/cm-water

Publishing support provided by the Rolla Publishing Service Center 

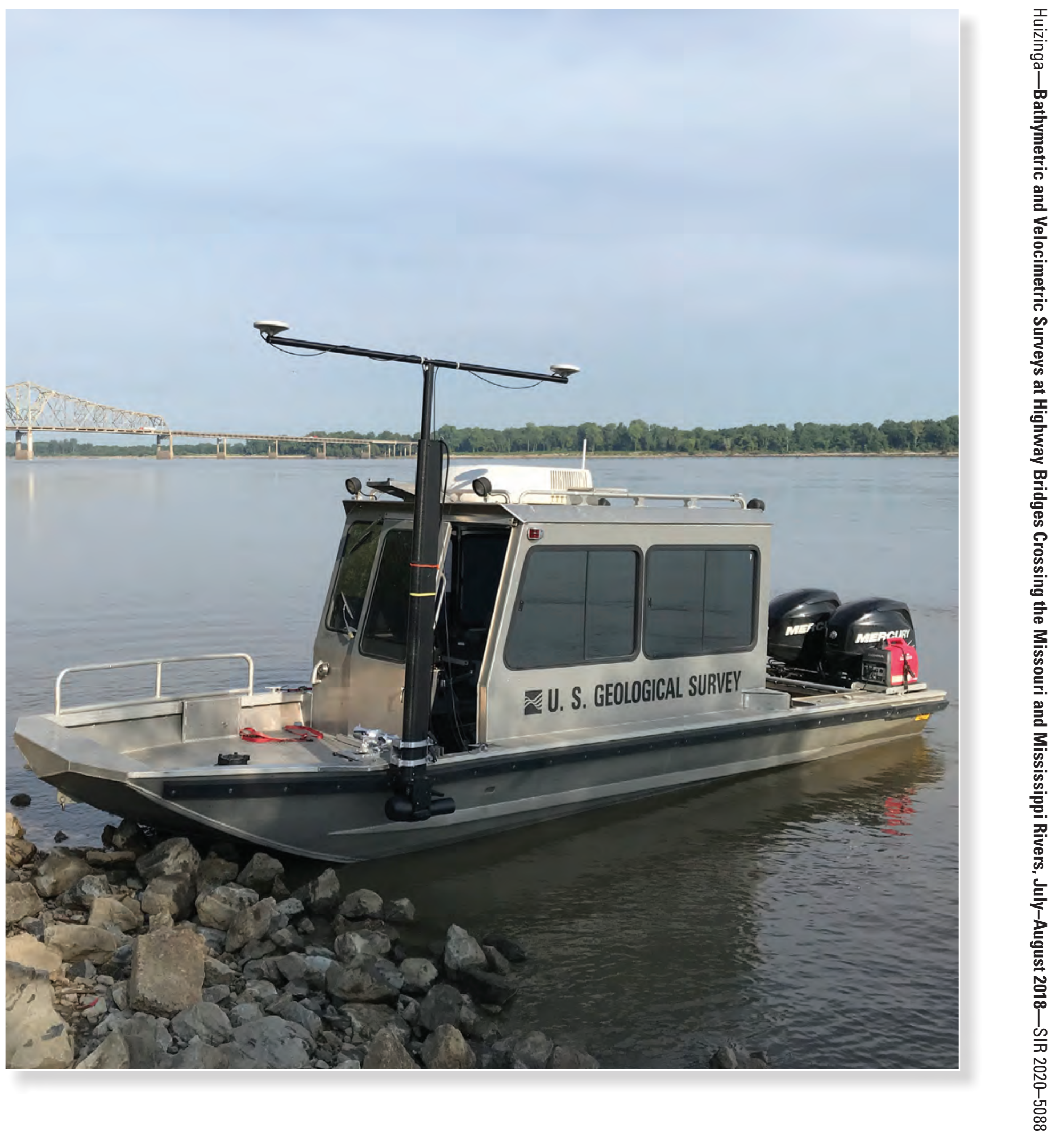